\title{
PLANTERS AGAINST PEASANTS
}





\section{VE R H A N D E L I N G E N}

VAN HET KONINKLIJK INSTITUUT

VOOR TAAL-, LAND- EN VOLKENKUNDE

\section{7}

KARL J. PELZER

\section{PLANTERS AGAINST PEASANTS}

THE AGRARIAN STRUGGLE IN EAST SUMATRA

1947-1958

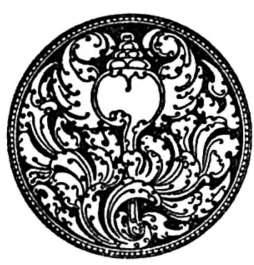


(C) Copyright 1982 by

Koninklijk Instituut voor Taal-, Land-en Volkenkunde, Leiden, The Netherlands.

All rights reserved, including the right to translate or to reproduce this book or parts thereof in any form. Printed in The Netherlands

ISBN 90.247.6182.4 


\section{CONTENTS}

Introduction by Clifford Geertz VII

Editorial Note $\quad$ XII

List of Abbreviations $\quad$ XV

List of Tables $\quad$ XVIII

Chapter I The Negara Sumatera Timur and the Agrarian Issue 1

Chapter II The Republic of Indonesia and the Agrarian Problem

Chapter III The Indonesian Communist Party and the Agrarian Issue 30

Chapter IV The Agrarian Controversy in Sumatera Timur from the Time of Transfer of Sovereignty to the Tanjungmorawa Incident

Chapter V The First Ali Sastroamidjojo Cabinet and the State Commission for the Division of Estate Lands in East Sumatra (1953-1954)

Chapter VI Years of Mounting Frustration for the Planter (1955-1956) 110

Chapter VII The Nationalization of Dutch Plantations 147

$\begin{array}{ll}\text { Notes } & 171\end{array}$

$\begin{array}{lr}\text { Index } & 182\end{array}$ 



\section{INTRODUCTION}

In social history, as in so much else, special cases often turn out to be the most deeply representative: Venice, Cairo, California. East Sumatra, whose evolution from commercial enclave to political nightmare Karl Pelzer took as the subject of his last and finest work, is a most unstandard place. Nowhere else in Indonesia, not even Central Java, did plantation agriculture develop so extensively, so resourcefully, so profitably, or so destructively. Nowhere else did Western interests and Indonesian ones clash so directly, harden so completely, and grow so unmanageable. Nowhere else did ethnic diversity, ideological contrast, and class difference crystallize into so convolute a form; nowhere else was local administration so thoroughly enfeebled by national politics; and nowhere else were the death throes of colonialism more clamorous, more visible, or more drawn out. It is Pelzer's great virtue to have seen all this and yet to have seen that it exemplified a much more general process - the one that in dismantling the East Indies assembled Indonesia.

The beginnings of the story whose ending Pelzer tells here - the hapless struggle of the Dutch tobacco, rubber, tea, and oil palm growers to reestablish their enterprises in the supercharged political climate of revolutionary Indonesia - were set forth in his 1978 volume Planter and Peasant, which traced the development of the East Sumatran plantations during the colonial period, and to which the present work, unfinished at his death, was originally designed to be the concluding section. From 1863, when Jacobus Nienhuys first came to East Sumatra to set up an experimental tobacco plantation of seventy-five hectares worked by a couple of dozen Chinese laborers imported from Singapore, to the eve of the Second World War, when the land formally allotted to commercial exploitation - Dutch, German, British, American - reached upwards of half a million hectares, the region was utterly transformed. By that time, more than sixty percent of the cultivated land was European controlled, three- 
fifths of the population (itself quintupled) was Javanese or Chinese, and the area had become the single most important source of export earnings in the archipelago - "the dollar land", as Pelzer, who is not much given to vivid statement, puts it, "of Indonesia".

The changes he traced in that background work, which set the stage for the political pantomime he delineates here, were extremely diverse in kind. Juridical changes in property law, technological changes in agricultural methods, economic changes in investment, marketing, and employment practices, political changes in authority relations, sociological changes in community structure, and cultural changes in self-definition proceeded along their separate courses, separately fueled. But they all converged in the end to a single crux, never neutralized and never resolved: land use. Seventy-five years of the most intense agrarian modernization produced the most classic of agrarian conflicts: determined enclosers vs. defiant squatters.

The juridical issues - who had what sort of enforceable rights in what - were central to East Sumatran development from the beginning, and Pelzer gives more attention to them than to any other aspect of the matter, both in Planter and Peasant and in Planters against Peasants. The original granting of ill-defined, doas-you-will concessions by local rulers, with the nudging "approval" of the colonial government; the subsequent campaign by that government, conscience struck by what adventurism had wrought, to convert the concessions to properly drawn lease contracts fixing rights in black-letter clauses; the Sisyphean effort to mediate between formalized Roman-Dutch concepts of real property and a host of highly particular folk-law views of prior claim and appropriate use that such a conversion entailed: all this formed the rhetorical frame within which "the agrarian struggle" took place, until populist nationalism provided another. If this sometimes lends a rather academical tone to Pelzer's discussion - all those briefs, directives, commentaries, codifications, and algemene beschouwingen following one another into to oblivion of administrative history - and a sense of seeing things from the Governor's house, it is not because of a lack of feeling for concrete reality or some sort of parti pris. It is a result of the simple fact that law and lawyers set, before the war and for a fair while after it, the general terms of public argument.

In any case, the issues animating this clause and codicil discourse were anything but abstract, and Pelzer brings them out (again, some in this book, some in its predecessor) with biting 
clarity. On the technological level, there was the inherent conflict between labor-intensive plantation agriculture, particularly tobacco, and land-intensive shifting cultivation, which came to a head in a rising passion of debate over how much land the planters ought to leave to the indigenous population for subsistence cultivation. On the economic level, there was the virtually exclusive reliance on international marketing, which led to an active discouragement (in the case of tobacco, to an outright prohibition) of small-holder involvement in commercial agriculture, and on imported labor, which led to a massive influx of indentured workers, mostly Javanese. And on the political level there was the peculiar three-cornered, he pressures me, I pressure you, you pressure him, bargaining relation among outback planters, petty sultans, and field-level administrators, which excluded the mass of the Indonesian population, indigenous and immigrant alike, from any role in policy making at all. By the time the Japanese invaded in 1942, growing mercantile crops on preempted land with articled labor had become an extremely difficult proposition. By the time they left in 1945, it had become an impossible one.

Pelzer's concern in these final, broken-off pages of his work is to portray how the reality of this fact came at last to be clear to everyone - estate owner and civil servant, native ruler and nationalist politician, local farmer and intrusive laborer. The story of East Sumatra, violent, delusional, and Machiavellian by turns, between the end of 1946 when the Dutch returned and the end of 1957 when they were summarily dispossessed, is one of a gradually collapsing attempt to restore the unrestorable.

The movement, beginning during the Japanese occupation but continuing after it, of thousands of squatters, most of them former estate laborers, onto the estates altered the whole nature of the land use issue. What had been a matter of allowing indigenous farmers to grow subsistence crops for a time under tight regulation on fallowed estate land became a matter of coping with the occupation of large tracts of such land as private homesteads by erstwhile field hands. The great migration, this one spontaneous, into the area, otherwise Muslim, of ambitious, welleducated, Christian Bataks - Rhenish Lutherans, no less - from the interior highlands around Lake Toba as clerks, tradesmen, and minor professionals (as well as, to a degree, squatters too) which began in force right after the war and increased steadily thereafter, added yet another disturbing "foreign" element to the already explosive ethnic mix. The so-called "social revolution" of 
early 1946, in which a large part of the Malay aristocracy was massacred and much of the rest of it imprisoned by Republican irregulars, destroyed the power of the native states. The rise of mass labor organizations, most of them Communist-dominated, provided for the first time a popular force of enormous consequence. And the very Revolution itself introduced democratic concepts of citizenship and social rights equally inimicable to colonial law and tribal custom.

The decade, 1947-1957, upon which Pelzer concentrates his attention in Planters against Peasants, was thus one of those times - more rare than the crisis-mongering nature of much of modern historiography would suggest - when one species of social order disappeared and other species formed. The Dutch attempt to reinstate the prewar legal regime in the federalist "State of East Sumatra" foundered in the face of ethnic conflict, class bitterness, and nationalist radicalism. The efforts by the planters and the more accommodative elements in the Republic to remove the squatters and reenclose the estate lands led to a series of violent confrontations between estate tractors and hoe-waving peasants, to incessant maneuvering among highly ideologized peasant unions, social movements, and political parties, and to a string of standstill agreements with all the force of Mideast ceasefires. The growing militancy of Sukarno integralism - "one nation, one language, one people" - led to the projection of the East Sumatran conflict into the all-Indonesia stage. When his campaign in the United Nations to recover West Irian failed in November 1957, he declared martial law, expropriated the Dutch estates, and turned them over to the army to run. Pelzer calls it "the end of the road". But the road had really ended fifteen years earlier. What ended here, and ends with Pelzer's fragmentary final pages on the military takeover - themselves a portent of things to come - was what Francis Hutchins, speaking of the British in India, once called "the illusion of permanence".

Karl Pelzer is, of course, not the only scholar to write of all this. Anthony Reid, Michael van Langenberg, R.W. Liddle, Mohammad Said, and Clark Cunningham (himself a student of Pelzer's) have also made critical contributions, and important work is continuing, especially in Australia and Indonesia. ${ }^{1}$ But in

1. Anthony Reid, The Blood of the People: Revolution and the End of Traditional Rule in Northern Sumatra, Kuala Lumpur, Oxford University Press, 1979; Reid, "The Birth of the Republic in Sumatra", Indonesia, 12:12-46 (1971); Michael van Langenberg, "Class and Ethnic Conflict in Indonesia's Decolonization Process: A Study of East Sumatra", Indo- 
his pages, the relationships between geographical, agricultural, economic, political, legal, sociological, and cultural factors are treated with a breadth, precision, balance, and sensitivity altogether exemplary. Our regret that he did not live to provide us with his general conclusions is more than offset by the distinction of what he has here accomplished.

\author{
Clifford Geertz \\ Institute of Advanced Study \\ Princeton, U.S.A.
}

nesia, 33:1-30 (1982); R.W. Liddle, Ethnicity, Party and National Integration: An Indonesian Case Study, New Haven, Yale University Press, 1970; Muhammad Said, "What was the 'Social Revolution of 1946' in East Sumatra?”, Indonesia, 15:145-86 (1973); Clark E. Cunningham, Postwar Migration of the Toba Bataks to East Sumatra, New Haven, Yale Southeast Asian Studies, Cultural Report Series, No. 5, 1958. See also, inter alia, A.A. Schiller, The Formation of Federal Indonesia, The Hague, Van Hoeve, 1955; John R.W. Smail, "The Military Politics of North Sumatra, December 1956-October 1957', Indonesia, 6:122-87 (1968); Douglas Paauw (ed.), Prospects for East Sumatran Plantation Industries, New Haven, Yale Southeast Asian Studies, Monograph Series, No. 3, 1962; J.A.C. Mackie, "Indonesia's Government Estates and Their Masters", Pacific Affairs, 34:337-60 (1962), and Pelzer's own "The Agrarian Conflict in East Sumatra", Pacific Affairs, 30:151-59 (1957). 


\section{EDITORIAL NOTE}

Professor Karl J. Pelzer submitted the manuscript of the sequel to his Planter and Peasant, Colonial Policy and the Agrarian Struggle in East Sumatra 1863-1947, published in the Verhandelingen series of the Royal Institute of Linguistics and Anthropology in 1978, to the Institute's Editorial Department in April 1980. He stated in an accompanying letter that the manuscript lacked "the final chapter which will deal with the destruction of the Communist Front Organization or the Barisan Tani Indonesia. I am on my way to Indonesia and plan to spend five months in Sumatra in search of material for a final chapter. I intend to write the final chapter in Medan. As soon as the chapter is written I shall send it to you". Professor Pelzer died on 9 th November 1980. The promised final chapter had not yet been received by the Institute at that time.

With the permission of Prof. Pelzer's widow, Ms. Elizabeth Pelzer, it was subsequently decided to publish the manuscript in the form it had been left by the author. Even without a final chapter it forms a reasonably rounded off whole, which is not in absolute need of further addition. Following this, Professor Clifford Geertz undertook, at our request, to write a foreword for this last, posthumously published book of Prof. Pelzer's. In it he sets out the significance of Prof. Pelzer's books on the economic history of East Sumatra.

In the editorial preparation of the manuscript the general rules normally used for Institute publications were followed. Geographical names and names of organizations have been respelt according to the current orthography, while personal names have been left in the old spelling.

A list of abbreviations used and an index were compiled by the Editorial Department. In a few cases, however, it proved impossible to trace the meanings of particular abbreviations.

We have decided against adding a bibliography because the sources consulted by Prof. Pelzer are mostly unpublished reports 
and archive documents. All the relevant bibliographical information on these as well as on the published literature consulted may be found in the notes. 



\section{LIST OF ABBREVIATIONS}

ALS

ASSI

AVROS

BANAS

BAPPIT

BKOTSU

BPM

BPR

BP4R

BPRP

BPRTI

BTI

BUD

CPM

DI

FPT

Gaperta

Gappersu

Geraktani

GOBSII

GTI

HVA

KBKI

KBSI
Algemeen Landbouw Syndicaat - General Agriculture Syndicate

Algemeen Syndicaat van Suikerfabrikanten in Indonesië General Syndicate of Sugarproducers in Indonesia

Algemeene Vereeniging van Rubberplanters ter Oostkust van Sumatra - General Association of Rubberplanters on Sumatra's East Coast

Badan Nasionalisasi Perusahaan Belanda - Nationalization Board of Dutch Enterprises

Badan Pusat Penguasa Perusahaan-Perusahaan Industri dan Tambang Belanda - Central Administrative Committee of Dutch Industrial and Mining Enterprises

Badan Kerja-Sama Organisasi Tani Sumatera Timur - Coordinating Committee of Peasant Organizations of East Sumatra

Bataafsche Petroleum Maatschappij - Batavian Oil Company unknown

unknown

Badan Perjuangan Rakyat Penunggu - Council for the Struggle of the Autochthonous People unknown

Barisan Tani Indonesia - Indonesian Peasant Front

Badan Urusan Dagang - Committee for Trade Matters

Corps Polisi Militer - Military Police Corps

Darul Islam

Front Persatuan Tani - United Peasant Front

Gabungan Persatuan Buruh Tani - Federation of Unions of Agricultural Laborers

Gabungan Pengusaha Perkebunan Sumatera - Sumatra Planters Association

Gerakan Tani - Peasant Movement

Gabungan Organisasi Buruh Sarekat Islam Indonesia Federation of Indonesian Islamic Labor Unions

Gerakan Tani Indonesia - Indonesian Peasant Movement

Handelsvereeniging "Amsterdam" - Trade Association

"Amsterdam"

Konsentrasi Buruh Kerakyatan Indonesia - Indonesian Peoples' Labor Federation

Kongres Buruh Seluruh Indonesia - All-Indonesian Labor Congress 
KPM

KPPT

KRPT

KTI

Masyumi

Nasakom

NHM

NU

OB Pancasila

OBSI

Oldefos

PARDIST

Parkindo

PDN

Permesta

Perti

Petani

Petanu

PIR

PKI

PN

PNI

PPN

PPN-Baru

PPNKST

P4SU

PPUTP

PRN

PRRI

PSI

PSII

PST
Koninklijke Paketvaart Maatschappij - Royal Mailship Company

Kantor Penyelenggara Pembagian Tanah - Office for the Execution of Land Distribution

Kantor Reorganisasi Pemakaian Tanah - Office for the Reorganization of Land Use

unknown

Majlis Syuro Muslimin Indonesia - Consultative Council of Indonesian Moslems

Nasionalis-Agama-Komunis - Nationalism-Religion-Communism

Nederlandsche Handel Maatschappij - Netherlands Trading Company

Nahdatul Ulama - Islamic Scholars

Organisasi Buruh Pancasila - Pancasila Labor Organization

Organisasi Buruh Sosialis Indonesia - Indonesian Socialist

Labor Organization

Old Established Forces

Partai Daerah Istimewa Sumatera Timur - Party of the Special Territory East Sumatra

Partai Kristen Indonesia - Indonesian Christian Party

Perusahaan Dagang Negara - State Commercial Enterprises

Perjuangan Semesta - Over-all Struggle

probably Persatuan Tarbyah Islamyah - Islamic Educational Movement

Persatuan Tani Nasional Indonesia - Indonesian Nationalist Peasant Union

Persatuan Tani Nahdatul Ulama - Nahdatul Ulama Peasant Union

Partai Indonesia Raya - Great-Indonesia Party

Partai Komunis Indonesia - Indonesian Communist Party

Perusahaan Negara - State Enterprises

Partai Nasional Indonesia - Indonesian Nationalist Party

Pusat Perkebunan Negara - Government Estates Administration

Pusat Perkebunan Negara Baru - New Government Estates Administration

Panitya Persiapan Negara Kesatuan untuk Sumatera Timur

- Preparatory Commission for the Incorporation of East Sumatra into the Unitary State

Panitya Penyelenggara Pembentukan Propinsi Sumatera Utara - Committee for the Establishment of the Province of North Sumatra

Panitya Pusat Urusan Tanah Pertanian - Central Commission for Agricultural Land Affairs

Partai Rakyat Nasional - National People's Party

Pemerintah Revolusioner Republik Indonesia - Revo-

lutionary Government of the Republic of Indonesia

Partai Sosialis Indonesia - Indonesian Socialist Party

Partai Sarekat Islam Indonesia - Indonesian Islamic Party

Persatuan Sumatera Timur - East Sumatran Union 
RCMA Rubber Cultuur Maatschappij “Amsterdam" - Rubber Plantation Company "Amsterdam"

RTC Ronde Tafel Conferentie - Round Table Conference

RTI Rukun Tani Indonesia - Indonesian Peasant Union

Sakti Sarekat Tani Indonesia - Indonesian Peasant Association

Sarbumusi Sarekat Buruh Muslimin Indonesia - Indonesian Moslem Workers Union

Sarbupri Sarekat Buruh Perkebunan Republik Indonesia - Indonesian Estate Workers Trade Union

SBII

Sarekat Buruh Islam Indonesia - Indonesian Islamic Labor Union

SBKI Serikat Buruh Kristen Indonesian - Indonesian Christian Labor Union

Sekata

SOBSI

Serikat Kaum Tani - Peasants Union

Sentral Organisasi Buruh Seluruh Indonesia - All-Indonesian Central Labor Organization

STII

Sarekat Tani Islam Indonesia - Indonesian Islamic Peasants Union

TII

Tentara Islam Indonesia - Indonesian Islamic Army 


\section{LIST OF TABLES}

1 Squatter population of Region I (area between Deli and Bingai rivers) as of 1948

2 Región I: Total area, land belonging to concessions, and land requirements of autochthonous population as of 1948

3 Area and number of households in the four villages of Nagori Asih, Merubun, Dolok Merubun and Huta Bayu Merubun

4 Ethnic composition of the population of the villages of Huta Bayu Merubun, Dolok Merubun, Merubun and Nagori Asih in 1948

5 Ethnic composition of the population of Tongah Maligas, Karang Mulia, Suhi Nagodang, Suhi Mahasar, and Jawa Tenga in 1948

Maximum permissible size of farm holdings

7 Major political parties and their affiliated labor and peasant organizations

8 Land applicants registered by KPPT by 1 January 1953

9 Land distribution program of KPPT in Serdang, Deli and Langkat, May 1953

10 Sentences issued by the courts of East Sumatra (1955)

11 Estates in the kabupaten Deli-Serdang and Simelungun and the extent of illegal occupation

12 Squatter situation on three estates of the United Deli Company and two estates of the Senembah Company 


\section{CHAPTER I}

\section{THE NEGARA SUMATERA TIMUR AND THE AGRARIAN ISSUE}

By mid-1947 the Republic of Indonesia was under attack from two sides in East Sumatra. "On 21 July, Dutch troops in Sumatra and Java began their first full-scale military campaign against the Republic. In East Sumatra Dutch planes dropped leaflets with Malay, Batak, and Acehnese texts claiming that the Dutch were coming not as enemies but to restore law and order... Wellequipped armored columns pushed out from the bridge-head of Medan with the intent of bringing the valuable plantation belt of East Sumatra under their control and thus clearing the way for the planters, who no less than twenty-two months after the Japanese surrender were still waiting impatiently for an opportunity to return to their plantations."1 Meanwhile, anti-Republic local leaders began to agitate for East Sumatran autonomy.

The Netherlands Indies commissioner for administrative affairs, J.J. van de Velde, the ranking military officer in East Sumatra, Colonel P. Scholten of the " $Z$ " Brigade, and the head of temporary administrative services, J. Gerritsen, formally reviewed a demonstration for East Sumatran autonomy held in Medan on 31 July 1947. Acting as spokesman for the demonstrators, Djomat Purba, a member of the Simelungun nobility, explained that the autochthonous people of East Sumatra wished to bring to the attention of the Netherlands Indies government some sentiments the people had been holding back since independence. The heart of the matter was resentment of Republican power, which had led to replacement of "representatives of the autochthonous population" in the administration of East Sumatra by self-seeking individuals little interested in the welfare of the local people and, worse, to the terror of the Social Revolution. With not one Malay left in any position of importance, the time was clearly come for the people, in concert with the Netherlands Indies government, to act to restore their rights. Djomat Purba then presented a petition requesting recognition of a committee of indigenous leaders whose purpose was establishment of an 
autonomous "Special Territory" of East Sumatra (Daerah Istimewa Sumatera Timur) in accordance with the Linggarjati Agreement's provision. ${ }^{2}$

Replying for the Netherlands Indies government, Van de Velde commended Djomat Purba and the rest of the committee for their great courage in making public their readiness to cooperate with the Netherlands Indies government and promised to bring the petition to the attention of Dr. H.J. van Mook, the Dutch Lieutenant Governor-General in Jakarta. The committee was urged to proceed meanwhile with plans for translating its ideas into realities.

Similar demonstrations were staged during the next few weeks in Lubukpakam, Binjai and Pematangsiantar. Meanwhile Republican extremists retaliated by killing several relatives of Daerah Istimewa Sumatera Timur supporters. The movement gained momentum following a mass meeting in Medan on 27 September at which Datuk Hafiz Haberham announced formation of the Partai Daerah Istimewa Sumatera Timur (PARDIST) by the fusion of two smaller wartime underground organizations. The older of the two, Persatuan Sumatera Timur (East Sumatran Union), also had a prewar history dating back to its founding in 1936 by Tengku Mansur. The other, Selamat Sejahtera (Welfare and Happiness), was the wartime creation of Datuk Hafiz Haberham, the new PARDIST leader. Both organizations had fought the Republicans from the beginning, but neither had dared come into the open until after the arrival of substantial Dutch forces. ${ }^{3}$

Victory came to the autonomists on 8 October 1947 with promulgation of a Netherlands Indies decree giving provisional recognition to the Daerah Istimewa Sumatera Timur and transferring to the Medan committee members as a temporary representative council the powers formerly delegated to the sultans and other petty princes. The council was additionally charged with the task of drafting a constitution. A decree officially creating the Negara Sumatera Timur (State of East Sumatra) was signed on 25 December by Van Mook.

Under a constitution closely modeled on that of the Negara Indonesia Timur (State of East Indonesia) and approved in February 1948, a state government was set up comprising a Chief of State (Wali Negara), a five-member Cabinet, a Representative Council (Dewan Perwakilan), and a Board of Delegates (Badan Amanah). The Representative Council had thirty-eight elected and twelve appointed members, who in turn chose seven from their own ranks to serve on the Board of Delegates, a kind of 
working committee for the larger body. ${ }^{4}$ Three Indonesians and two Dutch officials filled the posts in the first Cabinet and Tengku Mansur, doyen of the autonomy movement and an uncle of the former sultan of Asahan, was elected Wali Negara by the Representative Council.

The official transfer of power to the Negara Sumatera Timur on 9 March 1948 followed too quickly to allow adequate preparation, so that actual administrative transfers in Agrarian Affairs, Agriculture, Forestry, Public Health, Public Works, and other such services were still being made many months afterward. An immediate increase in the number of Indonesians was apparent in all offices but with so few Indonesians being professionally qualified, most of the top positions continued to be held by Dutch officials who, although theoretically responsible solely to the new Chief of State of the Negara Sumatera Timur, in practice reported also to their respective services in Jakarta and kept an eye on Dutch interests. ${ }^{5}$

\section{The Postwar Plantation Situation}

Overshadowing all other problems inherited by the new government was the great agrarian tangle, immensely complicated by the fact that the war had not only interrupted negotiations on the conversion question but also brought the plantation economy to a standstill. Returning planters hardly recognized their holdings. Above and beyond the effects of years without proper management, all plantations had suffered the inroads of wartime food crop cultivators. There were wide differences in the extent of the damage from the conversion of lands to food production, depending on the type and location of the plantation. Those lands nearest to population centers or to major roads and those lands most readily convertible, i.e. the tobacco fields, had borne the brunt of the wartime damage. It was possible for a few less accessible estates whose stands of perennial crops had to varying degrees been left untouched to go back into production immediately. A much more serious situation existed where large stands had been cut to make room for food cultivators, as the continuing presence of these squatters made systematic replanting impossible, thereby gravely handicapping plantation operations. But the tobacco planters faced by far the most discouraging prospect. A considerably higher percentage of their fields had been used for food production and, as to growing tobacco, it was practically impossible to find stretches of land that had been fallow the 
requisite eight or more years. Everywhere the second-growth forests so typical of the tobacco region in prewar years had given way to the tall alang-alang. Tegalan, patches of sawah, and truck gardens pockmarked estate lands. Even a beginning to the restoration of the field rotation system hinged on the chances of evicting thousands of squatters.

There was little more encouragement for the returning planters in the political climate though some reassurance could be found in the fact that, in contrast to the Republic of Indonesia where the essential prewar agrarian laws - the legal foundation of plantation agriculture - were being repealed, the Negara Sumatera Timur was headed by Tengku Mansur, who had just published an article stating:

“... no Indonesian with a sense of reality will doubt the fact that Indonesia also in its newly won state of independence will require help and support from the Dutch for many years - if not generations. The Dutch element is truly rooted in this land. It possesses attributes and knowledge which the great majority of Indonesians lack but which are absolutely necessary for the further progress and development of this part of Asia. ... It would be a twisting of historical facts if we did not admit that this area ... owes most of its prosperity and development to the pioneering spirit of Dutch entrepreneurs. Without doubt, East Sumatra would never have gained such an overwhelming economic importance had the Dutch planters not wrested such great wealth from the fertile soil with their daring and spirit of entrepreneurship, if the West had not invested such large sums of capital in plantation agriculture. ... Netherlanders like Nienhuys, Cremer, and Janssen were the ones who converted the jungle and swamps of East Sumatra into a region which still has enormous economic potentialities.

No honest person can deny that this gives the European entrepreneurs a sort of birthright - and even under the new circumstances this right is not affected. This is an obligation for us, one of which we will have to take cognizance ... for reasons of right and justice but also because of the fact that the continuation and further development of Western enterprises in this State must be regarded as of general interest to the people." 6

By itself this apologia for the plantation economy - for what Mansur at another point in his article referred to as "the goose that lays the golden eggs" - could have generated a real wave of 
optimism amoung the planters, but there were other factors to consider. An indication of the precarious balance a political leader had to maintain between economic and social pressures can be found in the next few sentences:

"However, this can hardly be a one-sided obligation. The entrepreneur, too, has his obligations, his new responsibilities, which stem from the awakening of the Indonesian people. These obligations are of a socio-economic nature ..."7

Government and planters alike recognized the dilemma presented by the squatters. Their occupation of plantation land admittedly had a quasilegal basis, the majority being able to cite the Compulsory Cultivation Ordinance of 1939, various decrees of the Japanese military, or the 1 May 1947 order of the Resident to the Republican Agricultural Service. ${ }^{8}$ There was also the squatters' sheer number, made up, as surveys in 1947 showed, of both Javanese and Chinese prewar plantation laborers, autochthonous villagers, Chinese market gardeners and hog breeders (some of prewar status and some who turned to these occupations after 1942), as well as various immigrant groups from North Tapanuli and other parts of Sumatra who had remained outside the plantation sector.

An arbitrary policy of immediate expulsion of all squatters - a policy openly advocated by a few planters - seemed inadvisable on several counts. There was, first of all, the continuing food crisis, whose possible alleviation with rice imports was still precluded by the stringent quotas of the international postwar rice allocation system. Another impediment to summary action arose from local political realities. The squatters, as citizens and prospective citizens, constituted an important voting bloc which the pro-Dutch government had to satisfy or risk losing to the Republican cause.

It was the clear need for a cautious approach that had led to the compromise whereby the planters had agreed to give temporary occupation permits to those squatters already on their land in return for a government promise to enact new laws for the protection of plantation property by 31 May 1948 . The Netherlands Indies government finally issued an ordinance against squatting on 8 June 1948 and the Negara Sumatera Timur, which meanwhile had assumed power, declared the ordinance effective in East Sumatra. This new law, ${ }^{9}$ established 8 June 1948, acted as a standfast beyond which unauthorized new squatters on public 
domain or plantation lands became subject to immediate eviction and to either a prison term of three months or a fine of five hundred Rupiah. Squatters from before 8 June 1948 received official permission to stay in their fields until satisfactory resettlement arrangements could be made for them.

Fully aware that any resettlement of squatters raised anew the question of agrarian rights, the Negara Sumatera Timur prepared a guidance directive whose classification of squatters according to land rights may be summarized as follows: ${ }^{10}$

Autoch thonous population

Right to a land allotment as provided by concession agreements

Nonautoch thonous Indonesians since accepted into adat community

Former plantation laborers

Nonfarmers occupying land for speculative purposes

Refugees

Chinese and other foreigners

Agrarian rights but no claim on plantation lands

No land rights (expected to return to their jobs)

No land rights

No land rights (temporary arrangements to be made for their relief)

No land rights (free to make rental or long lease agreements as before the war)

The planters noted with approval the exclusion of immigrants or any other new category from the roster of land claimants and the government stand on the return of former plantation laborers to their jobs. There were encouraging steps toward restoring plantation operations. Looming ever larger, however, was the conversion question which by 1948 , with fourteen concession agreements already expired and most others soon to expire, carried a real sense of urgency.

The Social Revolution, which swept through East Sumatra in March 1946, had meanwhile robbed the planters of their best allies, the sultans, and thereby much of their great prewar influence over local affairs. 


\section{The Investigation of the Bureau of Land Planning}

Ir. J.H. de Haan, director of the Bureau of Land Planning, a new agency of the Netherlands Indies Department of Agriculture and Fisheries in Jakarta, made several trips to East Sumatra in 1948 and 1949 to study firsthand the complex land problem there, and his detailed reports constitute a rich source of information on agricultural conditions during this politically unsettled period.

As interesting as the statistical data is the general approach of De Haan. Recognizing the futility of attempting a solution of the agrarian problem on the basis of legal reasoning, since legal arguments were no longer acceptable to the Indonesians, whatever their political philosophy, De Haan and his staff set out to find a rational solution to the problem of how to delimit and relate, in a fair, economically sound, and politically acceptable manner, the agrarian rights of the peasants and the legal rights of the planters. To arrive at such a solution the Bureau of Land Planning intended first to undertake a careful reassessment of all economic and political factors as well as a scientific evaluation of the agricultural potential of the area considered as a whole.

Of the many factors to be examined, the purely economic necessarily ranked high. The Netherlands Indies government, like the Negara Sumatera Timur government, was firmly committed to the defense of the autochthonous population against all encroachments on their rights by the planters. Yet no one was more aware than De Haan of the importance to the general welfare of a healthy plantation economy. A solid basis for the argument lay in his figures comparing yields from tobacco cultivation in the years just before the war and yields from the crops being grown by Indonesians on roughly the same land in the postwar years. Statistics assembled for the years 1930 to 1938 showed that the tobacco plantations, using an average annual total of 13,000 hectares had produced an income of 19 million guilders (including the value of the rice grown after the tobacco harvest) for an average annual yield per hectare of 182 guilders. Estimates of Indonesian production, adjusted to prewar price levels, put the average income per hectare for a rice crop at 91 guilders and for a corn crop at 40 guilders. On the basis of the prevalent four-year cultivation cycle - two years of doublecropping and two years of fallow - these estimates indicated an average annual yield per hectare of 65 guilders. ${ }^{11}$

That the Indonesian production estimates might be high was implied in additional data showing that many peasants on former 
tobacco lands found their rice yields off as much as 20 percent the second year and 50 percent the third and that some peasants were allowing as much as four years of fallow. In such cases the annual yield fell to 40 or 50 guilders. But, as the Bureau of Land Planning pointed out, even an average annual income of 65 guilders compared unfavorably with the 240 guilders a man and his wife could earn by working on a plantation. Nor did this figure, based on the prewar averages of 150 guilders for a male laborer and 90 guilders for a female laborer reported by Baron van Lynden, include the medical care of high professional quality or other fringe benefits plantation employees enjoyed. All in all, De Haan concluded, a major shift in land use from plantation operation to the subsistence agriculture of the peasants would entail a serious economic loss for the country as a whole.

Just how to reconcile this fact with the inherent right of the indigenous population to land posed a problem with no easy solution. The postwar political ferment, anticolonialist and militant, precluded the use of legal arguments in dividing the land between plantation and indigenous sectors. De Haan knew this but knew too that the planters had to have a legal basis for their operations and that in a generation or two, unless other means of livelihood could be found for the growing population, an even greater land shortage would make the renewal of long leases politically impossible.

His recommendation was to give the plantations long leases for sufficient land to permit operations on approximately the prewar scale in return for the release of most of their reserve lands to the government for distribution to indigenous cultivators. De Haan estimated that the tobacco industry needed 120,000 hectares and could release 135,000 hectares. The perennial-crop plantations, retaining all land actually under cultivation, would have 160,000 hectares and could release 105,000 hectares. About a third of the 284,000 hectares of forest reserve was also to be released. ${ }^{12}$ It seemed reasonable to suppose that the total area of the released estate land and forest reserve, together with the remaining idle land in the public domain and various agricultural lands unclaimed after the war, would take care of the local cultivators, especially if all potentially irrigable land were converted to sawah.

The real departure from earlier proposals along these lines could be found in the ambitious plans for putting this reallocation of land on a sound scientific basis. Rather than try untangling the rights accrued from concession agreements signed up 
to seventy years before, or rather than leave to the planters the choice of lands to be released, the Bureau of Land Planning set out to make a thorough reappraisal and agrological classification of the entire agricultural area of East Sumatra as the basis for a permanent assignment of land to either the export or the subsistence sector of agriculture. All land was to be classified as to suitability for irrigated rice cultivation, forest reserve, perennialcrop cultivation after terracing, or plantation tobacco cultivation. Only by discarding the habit of seeing the land in terms of specific parcels or plantations and moving to consideration of the whole area of a hydrographic basin or watershed could a rational division of the land be made, and serious repercussions on plains, bottom lands, and coastal areas of any interference with their headwaters be avoided. Maximal development of the country's agricultural resources for the ultimate benefit of all interests depended on finding a scientifically sound solution to the land problem. The next stop was to organize a practical program for accomplishing this.

A branch of the Bureau of Land Planning was opened in Medan in April 1948 and the government began looking for such specialized personnel for the branch as an irrigation engineer, a land use expert, and a rural sociologist with a thorough knowledge of adat. Study maps of the area covered by the states of Langkat, Deli, and Serdang were made and the whole area divided into three regions, each extending from the coast southward to the highlands. Subregions were marked off on the basis of topographical unity, i.e. according to elevation and terrain, and a request forwarded to the central office for an aerial survey from which maps on a scale of $1: 20,000$ could be drawn. These plans were never fully implemented. The Medan office remained hopelessly understaffed during its short existence and, so far as I could determine from my own study of the records, the aerial survey was never begun.

More progress seems to have been made in the matter of a proposed census of the squatter population according to the categories defined earlier by the Negara Sumatera Timur. Table 1 summarizes some of the data gathered for Region I, an area bounded on the east by the Deli river and on the west by the Bingai river with a total of 104,000 hectares, of which the plantations held 73,830.

There were among the squatters only about 6,900 autochthonous families, whose valid claims to land would have totaled about 35,000 hectares, leaving roughly 39,000 for the tobacco 
Table 1

Squatter population of Region I (area between Deli and Bingai rivers) as of 1948

\begin{tabular}{|c|c|c|c|}
\hline $\begin{array}{l}\text { Location and } \\
\text { ethnic group }\end{array}$ & $\begin{array}{l}\text { Heads of } \\
\text { households }\end{array}$ & $\begin{array}{l}\text { Depen- } \\
\text { dents }\end{array}$ & Total \\
\hline \multicolumn{4}{|l|}{ Living in non-estate kampongs } \\
\hline Autoch thonous people & 6,341 & 19,005 & 25,346 \\
\hline Other Indonesians & 4,383 & 12,286 & 16,669 \\
\hline \multicolumn{4}{|l|}{ Chinese, Indians and } \\
\hline Other non-Indonesians & 803 & 1,444 & 2,247 \\
\hline Total & $\overline{11,527}$ & $\overline{32,735}$ & $\overline{44,262}$ \\
\hline \multicolumn{4}{|l|}{ Living dispersed } \\
\hline Autochthonous people & 510 & 1,456 & 1,966 \\
\hline Other Indonesians & 3,304 & 7,710 & 11,014 \\
\hline $\begin{array}{l}\text { Chinese, Indians and } \\
\text { other non-Indonesians }\end{array}$ & 517 & 1,141 & 1,658 \\
\hline Total & $\overline{4,331}$ & $\overline{10,307}$ & $\overline{14,638}$ \\
\hline \multirow{2}{*}{\multicolumn{4}{|c|}{$\begin{array}{l}\text { Living in estate kampongs } \\
\text { (almost without exception } \\
\text { Javanese) }\end{array}$}} \\
\hline & 9,182 & 23,472 & 2,654 \\
\hline Grand total & 25,040 & 66,514 & 91,554 \\
\hline
\end{tabular}

Source: J.F. Wolterson, Streekplan I, Medan, 18 June 1949. These figures differ somewhat from those found in the same author's Nota betreffende de conversie van de tabaksconcessies en de plaats die daarin de Sectie Landinrichting inneemt, March 1949.

plantations. These figures, for Region I as a whole, revealed nothing of the real problem, however, which lay in the concentration of autochthonous claimants in the only areas suitable for plantation tobacco cultivation. This uneven distribution of resources and population among the four topographical subregions marked off by the Bureau of Land Planning is shown in Table 2.

The indicated solution was clearly a major resettlement of people among subregions, together with the conversion of some tobacco land into sawah, and there were apparently some preliminary calculations along these lines. But whether the Bureau of Land Planning, given a longer existence, would have been able to devise a workable plan remains problematical in view of the many factors - social and political as well as economic - any 
Table 2

Region I: Total area, land belonging to concessions, and land requirements of autochthonous population as of 1948 (in hectares)

\begin{tabular}{|c|c|c|c|c|}
\hline Subregion & Total Area & $\begin{array}{l}\text { Land } \\
\text { belonging } \\
\text { to con- } \\
\text { cessions }\end{array}$ & $\begin{array}{l}\text { Land suited } \\
\text { for tobacco } \\
\text { cultivation }\end{array}$ & $\begin{array}{l}\text { Land needed } \\
\text { for autoch- } \\
\text { thonous } \\
\text { population }\end{array}$ \\
\hline 1 & 23,330 & 4,200 & - & $2,181.125$ \\
\hline 2 & 58,710 & 55,440 & 55,440 & $24,201.52$ \\
\hline 3 & 10,670 & 10,465 & - & $4,536.575$ \\
\hline 4 & 11,360 & 3,725 & - & $3,961.75$ \\
\hline Total & 104,070 & 73,830 & 55,440 & $34,880.97$ \\
\hline
\end{tabular}

Source: J.W. Wolterson, Streekplan I, Medan, 18 June 1949.

plan would have had to accommodate. The complexity of the squatter problem is perhaps best illustrated by closer examination of the actual situation on a typical plantation.

\section{The Squatter Problem on Marihat Estate: A Case Study}

A request from the Assistant Resident of Simelungun to the Negara Sumatera Timur in 1948 for an investigation of the squatter problem on Marihat Estate, a former German plantation near Pematangsiantar confiscated in 1940 as enemy alien property, resulted in a survey by the Bureau of Land Planning which highlights the predicament of many planters in postwar East Sumatra. The original concession of 5,200 hectares, known as Concession Bah Kasinder, had been granted on 18 March 1908 by the Raja of Tanah Jawa and the Pertuhan of Huta Bayu Merubun. Of three kampongs within the concession at the time, Jawa Dolok and Marihat Jandi had been bought out and the six families of the third kampong, Nagori Asih, given a total of 26.5 hectares of land and allowed to remain as an enclave within the plantation. In 1917 an adjoining concession, Belimbingin, was granted to the Handelsvereeniging "Amsterdam" (HVA), at which time three kampongs with the names Merubun, Dolok Merubun, and Huta Bayu Merubun were created on the northerly border of the Bah Kasinder concession. In careful compliance 
with existing legislation, the concessionaires allotted four hectares to each of the 51 households in these three new villages.

The situation was considerably changed by 1948 . In the villages a natural population growth had been augmented in the 1930s by an influx of unemployed Javanese plantation laborers. Their plight during the depression had caused general concern and the Netherlands Indies government, finding the offer of repatriation to Java only a partial solution, had put pressure on the Simelungun rajas to allow these laborers to settle in Simiclungun villages. ${ }^{13}$ In addition to the Javanese, there had been some migrants from Tapanuli. The resultant rise from 1917 to 1948 in the population of these four villages is shown in Table 3.

Table 3

Area and number of households in the four villages of Nagori Asih, Merubun, Dolok Merubun and Huta Bayu Merubun

\begin{tabular}{lccc}
\hline Village & $\begin{array}{l}\text { Area } \\
\text { (hectares) }\end{array}$ & $\begin{array}{l}\text { Number of } \\
\text { households } \\
\text { in } 1917\end{array}$ & $\begin{array}{l}\text { Number of } \\
\text { households } \\
\text { in } 1948\end{array}$ \\
\hline $\begin{array}{l}\text { Merubun } \\
\text { Dolok Merubun }\end{array}$ & 96.8 & 24 & 159 \\
$\begin{array}{l}\text { Huta Bayu Merubun } \\
\text { Nagori Asih }\end{array}$ & 71.7 & 9 & 103 \\
& 26.5 & 6 & 118 \\
\cline { 2 - 4 } Total & 231.3 & 57 & 49 \\
\hline
\end{tabular}

Source: Wolterson, Advies inzake grondbehoefte van de Pertuhanan Huta Baju Merubun, Simelungun, Medan, 27 December 1948.

In the census of these households, the Bureau of Land Planning also recorded ethnic background and these data for 1948 reveal the radical shift in ethnic composition from 1917 when the villages were populated entirely by Simelungun Batak (Table 4).

Able to question 251 of the 290 Javanese families, the Bureau of Land Planning found that 158 had been residents since before 1942, living mainly as tenants of Simelungun landowners, another 60 had turned to subsistence agriculture between March 1942 and July 1947, and 33 were new arrivals in the villages, having moved there since July 1947.

Their lands badly eroded and totally exhausted, the villagers from these four kampongs had poured forth with the encourage- 
Table 4

Ethnic composition of the population of the villages of Huta Bayu Merubun, Dolok Merubun, Merubun and Nagori Asih in 1948

\begin{tabular}{lcrrr}
\hline Ethnic group & \multicolumn{2}{l}{$\begin{array}{l}\text { Number } \\
\text { of house- of total } \\
\text { holds }\end{array}$} & $\begin{array}{l}\text { Number } \\
\text { of } \\
\text { persons }\end{array}$ & $\begin{array}{l}\text { Percent } \\
\text { of total }\end{array}$ \\
\hline $\begin{array}{l}\text { Local Simelungun } \\
\quad \text { Batak }\end{array}$ & 71 & 15.5 & 292 & 18.5 \\
$\begin{array}{l}\text { Simelungun Batak } \\
\quad \text { born in another }\end{array}$ & & & & \\
$\quad \begin{array}{l}\text { Pertuhanan } \\
\text { Javanese }\end{array}$ & 21 & 4.6 & 65 & 4.1 \\
Sundanese & 13 & 63.2 & 902 & 57.0 \\
Toba Batak & 42 & 2.8 & 41 & 2.6 \\
Mandailing Batak & 11 & 2.1 & 191 & 12.1 \\
Banjarese & 10 & 2.2 & 49 & 3.1 \\
Indo-Arabs & 1 & 0.2 & 6 & 2.3 \\
\cline { 2 - 5 }$\quad$ Total & 459 & 100.0 & 1,582 & 100.0 \\
\hline
\end{tabular}

Source: Wolterson, Advies inzake grondbehoefte van de Pertuhanan Huta Baju Merubun, Simelungun, Medan, 27 December 1948.

ment of the authorities in the war and postwar years to practice swidden cultivation on Marihat property. So too had the villagers from five other villages on the periphery of Marihat which were politically outside the jurisdiction of the Pertuhanan Huta Bayu Merubun (presumably all five were so-called "estate villages"). Census data for these villages yielded the ethnic breakdown shown in Table 5.

With 1,017 squatter families of altogether 3,695 persons, the Marihat managers did have a problem - and no one saw easy solutions. Here as elsewhere in East Sumatra the Bureau of Land Planning investigators faced the sometimes open hostility of squatters who knew their land was forfeit under the terms of the Negara Sumatera Timur directive. There was also a constant stream of new squatters despite reaffirmation on 22 May 1950 by Tengku Mansur, as head of Negara Sumatera Timur - at the time one of the states, belonging to the newly independent "United States of Indonesia" -, and Colonel M. Simbolon, the 
Table 5

Ethnic composition of the population of Tongah Maligas, Karang Mulia, Suhi Nagodang, Suhi Mahasar, and Jawa Tenga in 1948.

\begin{tabular}{llrlr}
\hline Ethnic group & $\begin{array}{l}\text { Number } \\
\text { of house- of total } \\
\text { holds }\end{array}$ & $\begin{array}{l}\text { Number } \\
\text { of } \\
\text { persons }\end{array}$ & $\begin{array}{l}\text { Percent } \\
\text { of total }\end{array}$ \\
\hline $\begin{array}{l}\text { Local Simelungun } \\
\quad \text { Batak }\end{array}$ & 139 & 24.9 & 506 & 23.9 \\
$\begin{array}{l}\text { Simelungun Batak } \\
\quad \text { born in another }\end{array}$ & & & & \\
$\quad \begin{array}{l}\text { Pertuhanan } \\
\text { Javanese }\end{array}$ & 172 & 7.5 & 160 & 7.6 \\
Sundanese & 3 & 0.5 & 620 & 29.3 \\
$\begin{array}{l}\text { Toba Batak } \\
\text { Mandailing Batak }\end{array}$ & 192 & 34.4 & 793 & 37.5 \\
Banjarese & 2 & 0.5 & 8 & 0.4 \\
$\quad$ Total & 558 & 100.0 & 2,113 & 100.0 \\
\hline
\end{tabular}

Source: Wolterson, Advies inzake grondbehoefte van de Pertuhanan Huta Baju Merubun, Simelungun, Medan, 27 December 1948.

military governor for North Sumatra, of the continued legality of the 8 June 1948 standfast ordinance against all such new squatting. The combination of a fluid situation and a limited staff made it all but impossible to complete a truly current census.

The data did, however, suffice for consideration of one aspect of the problem - allotment of land to rightful claimants - and the Bureau of Land Planning proceeded to make recommendations in three areas. First there were the indigenous claimants. The Negara Sumatera Timur directive explicitly excluded all nonindigenous people from those with a valid land claim and, in the case of Marihat, this was interpreted as applying as well to those Simelungun Batak outside the jurisdiction of the Pertuhanan Huta Bayu Merubun, i.e., in the five "estate villages", whose claims would have to be made in their home districts. This left only the 71 Simelungun Batak families of Nagori Asih, Merubun, Dolok Merubun, and Huta Bayu Merubun, with a total claim to 284 hectares. Of the 232 hectares allotted to Simelungun Batak families within the concession in 1917, only 135 were still in Simelungun Batak hands, 97 hectares having been acquired by 
Javanese families. Taking into account this loss of 97 hectares and the natural increase from 57 to 71 Simelungun Batak families, the Bureau of Land Planning advised the Marihat management to release 30 hectares of wet-rice land (the equivalent of 120 hectares of unirrigated land) for use by these families.

A second and larger category of claimants arose in the form of 367 families who though not Simelungun Batak had been assimilated into the adat community and given "citizen" status in the Pertuhanan. The great majority of these people, originally drawn from surrounding areas by the lure of wages, were former plantation workers and as such were expected to return to their jobs. To allow each of these families 0.4 hectares, adequate for a house and small garden, the Bureau of Land Planning suggested the release of an additional 150 hectares of potential sawah for their special needs.

The third recommendation related to the predictable natural population growth of the future. Clearly it would have been absurd to attempt a permanent solution to the problem of providing land for future generations but it would have been equally absurd to repeat the mistake of making no provision whatever. As a conciliatory gesture it was proposed that the total allowance of 180 hectares of potential sawah be raised by a flat 25 percent in anticipation of new claims within the Pertuhanan Huta Bayu Merubun, this additional land to be held in reserve by the government.

\section{The "Second Revolution"}

Thus things stood at Marihat and elsewhere when on 17 August 1950 the Republicans declared Indonesia a unitary state, abolishing at one stroke such "special" territories as the Negara Sumatera Timur and all other vestiges of the federal structure imposed by the Netherlands Indies three years earlier. The transfer of sovereignty on 27 December 1949 had in a formal sense ended the struggle for independence but, as history was to prove, also marked the beginning of an even more intense struggle for national identity. The creation of a unitary state was the first major victory in this "second revolution".

For the planters it was a period of immobilizing uncertainty. Signs that a radical change had just taken place were inescapable. In East Sumatra the incoming Republican acting governor almost immediately transferred responsibility for agrarian matters to the civil administration officials of the resident's office (kabupaten), 
reducing the Bureau of Land Planning to a purely advisory role. More ominous was the swift metamorphosis of the essentially economic conversion tangle into a political issue for the Republic of Indonesia with the question framed in terms of colonialism and foreign exploitation.

Yet it was difficult for the planters to judge if or when the Republicans would repudiate the agreements regarding the future of the plantations that the Netherlands Indies had so painstakingly attached to the transfer of sovereignty. For a year the planters had been relying on Republican guarantees, made somewhat reluctantly at the Hague Round Table Conference, of the recognition and restoration of all "rights, concessions, and license properly granted under the law of the Netherlands Indies" and the continuation of those conditions "rendering investments required for normal long-term operations possible" - any exceptions to be handled "in accordance with legally prescribed procedure".

At the same time the planters were uneasily aware of events in the territory administered by the Republic of Indonesia where the Republicans had used their five years of control to effect revolutionary changes in the agrarian situation in Java. 


\section{THE REPUBLIC OF INDONESIA AND THE AGRARIAN PROBLEM}

Whereas, for the sake of the economic benefits which the country would derive from the reconstruction of a flourishing plantation industry, the leaders of the Negara Sumatera Timur had been willing to agree to the return of the planters, the Republican government in Yogyakarta was overwhelmed by the popular demand for a thoroughgoing examination of the old agrarian legislation and for agrarian reform.

The first target turned out to be the plantations of the principalities in Central Java - the same plantations that had aroused Governor-General Van der Capellen's ire in 1823 and, contrarily, been defended by Du Bus de Gisignies in 1827. On 6 March 1948, possibly in response to demands coming from the grass roots, President Sukarno appointed an agrarian commission, known as Panitya Tanah Konversie, which was requested to study the agrarian problems of the Javanese principalities of Yogyakarta and Surakarta. Among the studies available to the commission was Soepomo's thoroughly documented thesis on the agrarian history of this region, written under the guidance of Van Vollenhoven in Leiden, in which Soepomo had demonstrated that the Western planters had drastically altered the agrarian structure in the principalities to the detriment of the peasants. ${ }^{1}$

Originally, as Soepomo pointed out, the Javanese ruler, who claimed to be the owner of all land and regarded his subjects as his tenants, had demanded a share of the crop, known as pajeg, amounting to one-half of the rice harvest on irrigated sawah, one-third of the rice harvest on tegalan and rain sawah (or sawah tadahan), and one-third of all dry-season crops. The princes often transferred parts of their lands to relatives or state officials as apanage lands with pajeg and other traditional services thereafter belonging to the holder of the apanage.

The Western planters who leased these apanage lands, or those lands still held by the princes, had no interest in a share of the 
ordinary crops, their concern being to produce the more profitable export crops - coffee, cacao, tobacco and sugar. This required control of the land, which the Western planters assumed by taking one-half of the village land subject to pajeg payment and compelling the Javanese to cultivate export crops without payment for their labor. In addition, the planters demanded other compulsory services, such as guard duty. In the course of the nineteenth century, the planters were able to exact more and more favorable terms from the princes, thus increasing the burden on the peasants. Strictly speaking, the Western planters, in the opinion of Soepomo and Van Vollenhoven, had no right other than to collect a share of the harvest and to demand the customary labor services from the population; specifically, they had no right to the land itself. But the planters proceeded deliberately to change the pajeg system into the glebagan and bengkok systems. Under the glebagan system, a planter would divide the arable land into two equal parts and rotate his fields, using one half himself in alternate years. Under the bengkok system, the land was also divided into two equal parts - one part designated estate land for the cultivation of perennials and the other part left in the hands of the peasants for production of their own food crops. This was a tampering with adat. Moreover, the traditional practice by rulers and high state officials of impressing Javanese for service on such special occasions as the funeral of a ruler was also converted by the planters into a basis for compulsory agricultural labor without compensation.

From time to time the Netherlands Indies government attempted to stop clear cases of violation of Javanese adat, but by and large the planters' demands for services grew unchecked. By 1900 the difference between the agrarian systems of the principalities and of those parts of Java under direct Dutch rule had become so great as to make the need for agrarian reform obvious to all. Therefore, after years of study and preparation, the government finally decided in 1909 to reorganize the agrarian structure of the principalities, with the following four major aims: abolition of the apanage system, assignment of more adequate agrarian rights to the Javanese peasants, formation of village communities, and revision of the system of taxation. It took another nine years to translate this decision into the reforms of 1918, amended in 1925. These reforms reflected the new view that the land-lease system of the principalities, which was based on special agrarian relations, no longer had a place in modern times and must be substituted by new regulations more 
in line with changing concepts of land rights. But since the planters were holding contractual rights they drove a very hard bargain, demanding the right to use their share of the village lands for another half century in exchange for the surrender of their "right" to compulsory unpaid labor services. This right became known as the "conversion right". For the Javanese peasants it meant not using one-half of the original village for another fifty years, despite the fact that their number had, beyond doubt, at least quadrupled since the beginning of the nineteenth century. The majority of the peasants found themselves no longer able to farm enough land to earn a decent living, and a high percentage of the families were completely landless - left with no choice, if they could not find employment in Java, but to become contract laborers in Sumatra.

Though the officially stated reason for the agrarian reform of 1918 was to give the farming population a more decent and independent position in society, the people were to wait no less than half a century for the final fruition of the reform which was considered absolutely necessary. This strange inconsistency of the government caused one Dutch observer to remark:

"Progress is not going to be suspended for fifty years, and yet the servitude imposed on agricultural land in the conversion area is fixed for half a century. The future will show whether the steady growth of the population, the rise of the educational level among the lowest strata of the population, and the accompanying increase in their requirements will not compel the government and the planters to follow another course, a course which must be directed towards an assimilation of the agrarian conditions in the principalities with those prevailing in regions under direct rule."2

It is therefore not at all surprising that in 1947-48 the peasants of Central Java clamored for an immediate reform and an abolition of the rights which the planters had been given under the terms of the 1918 agrarian reform.

The various peasant organizations which sprang up after the declaration of independence repeatedly passed resolutions urging the leaders of the Republic to abolish the conversion rights of the planters. In the forefront was the BTI (Barisan Tani Indonesia or Indonesian Peasant Front) which at its congress of 29 December 1946 held in Jember called on the government to buy all private landed estates, concessions, and long leases. A year later, at a congress held in Blitar on 16 December 1947, the BTI became 
even more emphatic, passing resolutions to demand the abolition of conversion rights and of all other vestiges of the Western planters' privileged position in the greatly overpopulated principalities of Java. Literally dozens of BTI branches passed similar resolutions. Meanwhile, on 13 November 1947, the People's Representative Council of Surakarta had gone on record for suspension conversion rights, a stand promptly endorsed by STII (Sarekat Tani Islam Indonesia or Indonesian Islamic Peasants Union). When to meet this rising clamor a special parliamentary committee finally recommended abolition of conversion rights, the BTI organized large demonstrations in Yogyakarta, Klaten, and other towns in the principalities to assure the members of Parliament that there was enthusiastic popular support for the motion.

The Panitya Tanah Konversie concluded that the peasants' demand for immediate abolition of conversion rights was entirely reasonable and just, since these rights were based on a feudal system in conflict with the principles of democracy and, in particular, with Articles 27 and 33 of the 1945 Constitution of the Republic of Indonesia. The commission further stated that continued imposition of the conversion rights was morally indefensible because the rights violated the fundamental principles of social justice by thwarting the economic development of the people and giving unfair advantages to the planters.

Furthermore, their continuation not only would disturb peace and order but would endanger the people's food supply. The commission was not opposed, however, to truly voluntary agreement between foreign entrepreneurs and Indonesian peasants, provided a higher land rental and higher wages were paid by the entrepreneurs. It was pointed out that such cooperation in the raising of export crops by the Indonesian peasants and their processing by the factories of the Western entrepreneurs would assure the continued vital flow of foreign-exchange-earning export crops. The commissioners submitted the draft of a bill revising the Land Lease Regulation of the Principalities (Vorstenlandsche Grondhuurreglement) to President Sukarno in a letter dated 28 March 1948. Parliament ended the conversion rights by Law No. 13 of 1948.

Admittedly rather hurried observations in Central Java in 1956 gave me the impression that the tobacco plantations did not resume their operations, despite the financial and economic conditions attached to the transfer of sovereignty. Most sugar planters had found their factories completely demolished as a 
result of the Republic's scorched-earth policy, in reply to Dutch military actions, so that they too did not at tempt to revive their operations. Those sugar factories which did operate bought most of the sugar cane from independent peasants or else rented land on the open market. The conversion rights had not been restored. A professor of Gadjah Mada University maintained that, even if the government had tried to help the planters to reestablish themselves in their former position, the resistance of the highly militant peasant and labor unions would have prevented it.

\section{The Panitya Agraria Yogyakarta}

On 21 May 1948 President Sukarno appointed an Agrarian Commission or Panitya Agraria (usually referred to as Panitya Agraria Yogyakarta to distinguish it from a later Panitya Agraria Jakarta which was established by presidential order of 19 March 1951). The 1948 Commission had sixteen members, including Chairman Sarimin Reksodihardjo and Vice-Chairman R. Gaos Hardjasoemantri, both from the Ministry of Interior. Besides government officials, the commission was made up of representatives of peasant organizations - such as BTI and STII - and members of Parliament; its assignment was to formulate the Republic's agrarian program.

The following is a summary of the objectives concerning agrarian matters to be found in the National Program which the Agrarian Commission recommended to Parliament in July 1949:

1. Unification of the agrarian law to eliminate the dualistic system, which distinguishes between Western and Eastern agrarian rights, and permit the development of collective and/or cooperative agriculture.

2. A system for giving each peasant a piece of land which can guarantee him and his family a decent living.

3. Expansion of the amount of land available for the peasantry through return to the State and redistribution of land belonging to plantations operating either under concessions or under long leases and small holdings operating under long leases.

4. Abolition of the private estates (particuliere landerijen) whose owners have seigneurial rights.

5. Granting of easy and cheap credit to peasants.

6. Formation of marketing cooperatives for the sale of products, both domestically and abroad. 
7. A program to free the rural people of all burdens which are a heritage of feudalism.

8. Protection of the small peasant who rents land by means of special legislation regulating the division of the crop yield.

9. Encouragement of small-scale village industries and of migration from Java to the Outer Islands.

10. Intensification of agriculture by means of seed improvement and expansion of irrigation systems.

11. A plan that would let the peasants share in the profits of factories to which the peasants deliver their products for processing.

12. State coordination and administration of irrigation works as well as state participation in the distribution of water. ${ }^{3}$

The most important goal was the first one, calling for a uniform agrarian law which would apply to all without regard to race or nationality. The Indonesian nationalists strongly resented the prewar dualistic agrarian law, which distinguished between a European legal sphere and an Indonesian sphere. Originally all land in Indonesia belonged to the Indonesian legal sphere, but beginning with the second half of the nineteenth century, and especially after 1870 , extensive areas were declared to be free state domain, that is, land unencumbered by any Indonesian rights. Westerners, both individuals and corporate bodies, were given jus in rem to this land by way of long leases, which in turn were entered in public registers. Besides the right of long leases, the European legal sphere knew the right to private ownership (recht van opstal). All land not subject to Dutch civil law belonged automatically to the Indonesian sphere.

In this sphere the student of adat distinguishes between: the right of disposal (beschikkingsrecht) ${ }^{4}$ which is held by a community and the rights of the individual, such as the native right of possession (hak milik), the right of usufruct, the right of preference to the land, the right of exclusive option, or the right of utilization of land belonging to one's kin group. ${ }^{5}$ There is some variation in the recognition of these rights from one group to another and differing emphases. Among the Karo and Toba, for example, the right of disposal by the marga which claims the land, combined with the rights of preference and exclusive option, makes it extremely difficult, if not outright impossible, for a person who is not a Karo or a Toba to acquire land in Karo or Toba communities. This is not the case in the coastal regions of East Sumatra, which do not observe Batak adat. While this 
regional difference in adat in respect to land cases the migration of Toba to East Sumatra, it would raise insurmountable obstacles for people of the coastal regions of East Sumatra or for Javanese if they wished to settle as peasants in Tapanuli.

The Netherlands Indies government was careful to guard against unbridled transfer of land from the Indonesian to the European legal spheres, even in instances where adat would have permitted it. This was done to prevent ignorant, improvident, or ill-advised Indonesians from selling or otherwise transferring their land to non-Indonesians, either Westerners or Orientals. Some Indonesian nationals with whom I discussed this particular aspect of Dutch agrarian law argued that it reduced the market value of land and effectively prevented an educated Indonesian headed for a profession or a business career from obtaining that amount of capital through the sale of his land that he would be able to receive were it legally possible for him to sell his land to buyers other than Indonesians - that is, Chinese or Westerners, who presumably would be able to pay a higher price than an Indonesian buyer would pay. ${ }^{6}$

Professor Soepomo, in 1947, suggested that in formulating an agrarian law Indonesia could learn from the example of the Soviet Union. There was nothing, however, in Article 38 of the Provisional Constitution of 1950 to indicate that Soepomo's suggestion was followed. In fact, Soepomo himself interpreted the same article to mean that the State would regulate the agrarian rights in all parts of Indonesia on land already under cultivation, as well as on primeval-forest land and on land not yet under cultivation; the latter would make unnecessary the practice, formerly common in the Netherlands Indies, of declaring waste land to be under state ownership. Further evidence that Soepomo's suggestion was rejected by the majority of the Agrarian Commission can be found in the recommendation that each peasant be given a piece of land that would guarantee him and his family a decent living, a basic distinction from Soviet agrarian law.

As to the agricultural concessions or long leases under which foreign planters operated their plantations, the Commission recommended a new type of agrarian right, hak usaha atas tanah, but this new right was not spelled out in enough detail to determine whether it would have come closer to the old Dutch law or to Indonesian adat.

In July 1949 the Republican government ordered the return of plantations to their rightful owners, but with the stipulation that 
their agrarian rights be brought into harmony with the government's new economic policy. This meant, in effect, that only those plantation lands requiring the investment of foreign capital or technical knowledge and management would be returned to the planters. Furthermore, the National Program of July 1949 stated that the holders of long leases would be expected to recognize and respect the new aims of the government regarding the social welfare of their laborers; that the foreign entrepreneurs would be expected to support the government in its efforts to improve the level of living of peasants and laborers; and that Western entrepreneurs, in taking advantage of the ample opportunities for investment of their capital, would have to be sure their activities were not conducted at the expense of the people or of the State.

In keeping with the financial and economic provisions of the Round Table Conference Agreement, concluded between the Indonesians and the Dutch in December 1949, the Indonesian government issued instructions early in 1950 regarding the return of the planters to those plantations which had not yet been reclaimed. It was stated that the provincial governor could upon request issue provisional permission for inspection and/or resumption of management of a plantation. The same instructions contained the following important provisions:

1. Regional committees were to be appointed for the preparation of the return of foreign enterprises in which would be included, besides officials representing the government, one representative each for the plantation company, for the labor organization, and for the peasant organization.

2. No infringement was to be permitted on the position of the laborers nor of the estate lands which had in the meantime been occupied by laborers and peasants.

3. Inspection and/or reestablishment of management would be permissable provided the entrepreneur accepted in advance the condition that he would submit to all future regulations of the government and that all laborers then working on the plantations would be left on their own jobs.

4. All work plans were to be submitted to the commission and had to show that the local people participated in the enterprise.

5. Every effort would be made to leave those estate lands that had been occupied by the people at their disposal, be it through expropriation or through cancellation of the long 
leases; the possibility was left open by way of negotiations to obtain the permission to continue the use of estate land on a loan basis and also to transfer the squatter to other parts of the estate if this could be proved necessary for technical reasons.

6. Where the squatters had to be removed from an estate, they had to be given sufficient time and aided in the transfer.

7. None of the above conditions were to be interpreted as constituting a renewal of the long leases.

In July 1950 the Minister of Interior ruled that in the case of plantations of great economic importance for the country whose long lease would expire before 1970 an extension of eight years would be made to compensate the management for its inability to operate the enterprise between 1942 and 1950. Such an extension would have been of questionable value to plantations whose leases had already expired, so owners of these plantations were invited to apply for a new lease. For all plantations with more than twenty years of unexpired long-lease time there was, in the opinion of the government, no need to grant the eight-year extension. This ruling reflected a spirit of moderation and a recognition of the importance of plantations as a source of foreign exchange. The moderate spirit was not, however, shared by the more extreme nationalists or by Communists.

Early in 1951 the Minister of Interior gave the provincial governors authority to renew long leases for a period of twentyfive years, plus a period of ten years for rehabilitation purposes, provided that (1) the enterprise was of great economic interest to Indonesia and its people, (2) the enterprise required capital and technical management not available in Indonesia, and (3) the squatter problem could be solved in a satisfactory manner. The goal was to convert the right of long lease into a new type of right once the new agrarian law had been written, to give the Indonesian capital an opportunity to participate in the management, and to make certain that the entrepreneur assisted local government in its efforts to improve the people's welfare in the respective territory.

In March 1952 the Minister of Interior directed a circular to all provincial governors on the proper steps to be taken to solve the agrarian problem of the plantation industry. He also stated the conditions under which a new long lease could be issued: the new long lease could have a duration of thirty years, to which could be added a rehabilitation period of ten years, and the rental had 
to be adjusted to current conditions with a review cvery five years. ${ }^{7}$ Furthermore, the entreprencur had to give Indoncsian capital an opportunity to invest in his enterprise, provide positions in management for Indonesians, replace staff members who in the opinion of the government had not made the proper adjustment, submit operational plans of the enterprise to the government for approval, keep the area of the plantation being used in the proper ratio to the number of laborers employed as established in the operational plan, maintain only the limited reserve area approved by the government, draw up a plan for the training of Indonesians for staff positions, and be prepared to assist in the improvement of the level of living of the people living around the plantation. The government reserved the right to cancel a long lease for violation of any of these conditions.

The Republic of Indonesia thus initiated a critical examination of the colonial agrarian legislation, but before it had the opportunity to draft a new agrarian law the transfer of sovereignty imposed the condition that Indonesia recognize all old contracts and leases which had not yet expired. This meant that it would take until about the year 2000 before the last of the long leases would expire. This took the urgency away. Nevertheless, every one of the seven cabinets between August 1950 and May 1959 had as one of its aims the drafting of a new agrarian law.

The task of writing a new agrarian law was, however, a most difficult one. The Panitya Agraria Yogyakarta called for a law which would be modern and suitable for the development of new enterprises but at the same time in harmony with both adat and Islamic law. This agrarian law had to be in harmony with the "living law" but at the same time had to permit rights which were clearly new concepts for the Indonesian community and thus had the character of a "positive law". By now, the difficulties of writing a law acceptable to the left-wing, moderate, conservative and extreme right-wing parties, as well as to the Indonesian rural folk and urban masses, had become only too apparent. Even if such a law had passed the drafting stage and been approved by Parliament it would have remained to be seen whether the government could have enforced it throughout Indonesia. The difference between an agrarian law based on adat and one based on modern legal principles, such as those found in Western law, is so great that it is hard to see how a law which meets all the demands of both could ever be written.

The development of a firm consistent policy in agrarian matters, with its concomitant, a clear-cut policy on the future of 
plantation agriculture, was made extremely difficult by the highly divergent views held by Indonesian leaders and by the various political parties.

All agreed that the colonial economic legislation, particularly agrarian legislation, had brought great profits to the Dutch state until 1870 and to Western entrepreneurs and corporations from 1870 on. All agreed that Indonesia must see to it that the product of Indonesian soil and labor benefited the country to a greater degree than in the past. But the Indonesian parties could not agree on the best policy for achieving this goal.

The moderates recognized the great importance of the plantations as earners of foreign exchange and were anxious to assure the future of plantation agriculture. They would have been satisfied with a legislative program that assured (1) better real wages for Indonesian laborers than they received before, (2) Indonesian participation in management, and (3) a higher tax rate than the Netherlands Indies had applied to Western enterprise. The moderates saw a need to attract new foreign private capital for certain sectors of the Indonesian economy while reserving other fields for Indonesian nationals or the Indonesian government.

The right-wing nationalists were opposed to foreign planters and demanded their expulsion with proper compensation, since they felt that if there were any sector in which Indonesians could work alone it was the agricultural sector. Many of them believed that plantations should be preserved as an institution, or form of economic enterprise, with management transferred to Indonesians. They recognized the need for foreign capital and technical skill in manufacturing and would have been prepared to accept new foreign investments, particularly in the form of government loans.

The left-wing nationalists, and particularly the left-wing Marxists, also demanded expulsion of all Western planters, but without compensation. The Communists were on record as demanding

"abolition of landlordism and its replacement by peasant control of the land. This can be effected only by confiscating the land of foreign and Indonesian landlords without compensation and redistributing this land without charge on an individual basis to the peasants, particularly to the poor and landless peasants, to be their private property. The abolition of these remnants of feudalism means laying down strong foundations for full national independence." 8 
Even the Communists, however, were ambivalent. Their demand for confiscation and wholesale distribution of land was followed by the statement that

"the confiscation of the land of foreign ... landlords does not mean that modern estates ... must be confiscated for distribution to the peasants. Technically, modern estates and also forest lands must be controlled by the State."

Actually, the government-owned and operated plantations in East Sumatra were just as much subject to illegal squatting by members of the BTI as were any foreign-owned plantation, this despite the demand in the "Urgency Program" of the BTI "to maintain and develop agricultural enterprises and state plantations". The ambivalence may be explained by Aidit's statement of early 1955:

"The PKI (Partai Komunis Indonesia, or Indonesian Communist Party) is of the opinion that Indonesia has to go through a bourgeois democratic revolution first before the proletarian revolution. At present Indonesia is in the stage of the bourgeois democratic revolution." 9

Even members of the same party often did not agree on the agrarian program. Basic differences within the ranks of the PNI (Partai Nasional Indonesia, or Indonesian Nationalist Party) and Masyumi (Majlis Syuro Muslimin Indonesia, or Consultative Council of Indonesian Moslems) were sometimes as great as the differences between the two parties. The two parties shared the power in the Wilopo Cabinet from April 1952 to June 1953. The Wilopo Cabinet was forced to resign because the PNI was in favor of nationalization of the North Sumatra oil fields, while Masyumi wanted to return them to the oil company. Masyumi was in favor of resettlement of all squatters on land which was to remain in the hands of the Western plantations; PNI wanted to stop all efforts of resettlement and attacked the Minister of Interior, Mohamad Roem, whose ministry was responsible for Governor Hakim's resettlement program. The immediate cause of the downfall of the Wilopo Cabinet was the Tanjungmorawa incident (see following chapter) but the basic causes had much deeper roots.

Government officials, aware of these differences between parties, knew only too well that action - even action in line with 
official instructions from Jakarta - might cause them great difficulties and even cost them their position. Postponement of action and the cautious avoidance of any action which could be interpreted as being in the interest of Western entrepreneurs and a violation of the spirit of the revolution was the inevitable result. 


\section{THE INDONESIAN COMMUNIST PARTY AND THE AGRARIAN ISSUE}

Sharing with Communist parties in other parts of the world the conviction that the industrial working class should be regarded as the most progressive, revolutionary, and receptive element of society, the Indonesian Communist Party (PKI) centered political activity exclusively on the workers in the immediate postwar years. Not until just before the abortive Madiun coup in 1948 did the Politburo admit its error and belatedly turn its attention to the peasantry. The Fifth National Party Congress, scheduled for later that year, was ordered to redirect the party's work program. But the stunning defeat of the party at Madiun in September caused such heavy casualties among party cadres that the surviving leaders were forced to curtail their work and fell back again to a concentration on the proletariat.

The first sign of a revived interest in the peasantry came as D.N. Aidit took over the leadership of the PKI in 1951. The party announced a new agrarian program in November 1951 that for the first time stressed the need of a worker-peasant alliance for the revolution, and by 1953 Aidit was urging party cadres to redouble their efforts to win the support of the peasantry. ${ }^{1}$ As a result of the lack of experts on the sources of agrarian discontent or on the peasantry in general, the party had not only failed to develop an agrarian program acceptable to the peasants but had actually antagonized a peasantry starved for land with such slogans as "nationalization of all land" and "the right of the state over all land". Aidit, aware of this, drew up a long list of new slogans based on the real grievances of the peasants, such as high land rents, high taxes, and compulsory village labor. ${ }^{2}$ Most applied more to Java than to other parts of Indonesia, but a few such as "land for the peasants", "peasants' personal ownership of the land", and "raise the wages of agricultural laborers" struck an immediate response throughout Indonesia, except possibly in the thinly settled swidden regions where land was still abundant.

The Fifth National Party Congress in March 1954 endorsed 
Aidit's plan to shift the main focus of the party from the workers to the peasants, acknowledging that "the agrarian revolution is the essence of the People's Democratic Revolution in Indonesia" - a concept to which the PKI adhered faithfully thereafter. But Aidit admitted that progress toward a united national front had been very disappointing for "we cannot possibly speak of a real, broad, and strong united national front until the peasants have been drawn into it ... the peasants comprise more than 70 percent of the population... As yet, only about 7 percent of the peasants are organized". Aidit set out to formulate a new approach whose immediate goals would be:

"to eliminate the survivals of feudalism, to develop the antifeudal agrarian revolution, to confiscate the land of the landlords, and to give it free of charge to the peasants, in particular to the landless and poor peasantry, as their own private property. The first step to be taken in our work among the peasants is to assist them in the struggle for their everyday needs... This is the foundation on which to create the alliance of workers and peasants as the basis of a powerful, united national front."3

Convinced that it was a mistake to view the peasantry as an amorphous mass, Aidit urged the cadres to take cognizance of the several classes of peasants in the villages and of the striking regional differentiation. His advice to the cadres, repeated on numerous occasions, was to study village conditions carefully in order to make the cadres' work more effective. But the response was slow, as evidenced in this complaint included in a party report to the PKI First National Peasants' Conference in 1959:

"The majority of Party cadres at the subsection and branch levels in the villages have not yet deeply studied the class divisions, the characteristics of each class and the class relations in the village. In general they are still unable to distinguish the landlord from the rich peasant, and still do not know the difference between the rich peasant and the medium peasant. This means that they do not yet thoroughly know who are the friends and who are the enemies of the revolution." 4

Aidit himself at first distinguished four categories in the village population: landlords, rich peasants, middle and poor peasants, and finally agricultural laborers. In the course of time his landlord and rich-peasant categories were elaborated by the identifi- 
cation of seven evil characters (setan-setan, or devils) who were exploiting the middle and poor peasants and the agricultural laborers. ${ }^{5}$ These seven village devils were: the wicked landlord, the usurer, the buyer of green paddy (tukang-ijon), the middleman, the bureaucratic capitalist (kaum kapitalis birokrat, or kabir), the manager, and the village bandit. ${ }^{6}$

As "survivals of feudalism", the landlords constituted the natural enemy of the revolution, and party cadres had no trouble tracing to their feudal privileges all the village ills. The four major grievances of the peasants as perceived by Aidit were: ${ }^{7}$

1. monopoly of land by the big landlords, which deprived the majority of peasants of an opportunity to own land of their own,

2. exhorbitant rents in the form of crop sharing, which impoverished large segments of the peasant population,

3. the right of landlords to requisition labor in lieu of rent, which reduced peasants to the position of serfs, and

4. the usurious interest rates, which enslaved the peasants in an accumulation of debts.

Having spearheaded the attack against the landlord class, Aidit, however, in his report to the Sixth National Party Congress in September 1959 proceeded for tactical reasons to exonerate "patriotic" landlords, at least for the time being, explaining that only "evil" landlords were the immediate target of the Communists. An "evil" landlord could be recognized by his sympathies with the Darul Islam, Tentara Islam Indonesia (TII), the PRRI-Permesta movement, and foreign imperialists and capitalists. The land of any such enemy of the nation should be confiscated and distributed free of charge to the peasants. The "patriotic" landlords, on the other hand, were to remain in the possession of their land. ${ }^{8}$ But, by 1964 the definition of an "evil" landlord had been expanded to include one who either openly opposed or deceitfully circumvented such progressive agrarian reform legislation as the Crop Sharing Law (No. 2/1960) or the Basic Agrarian Law (No. 5/1960). ${ }^{9}$

Aidit was ready to make other distinctions too. In contrast to the landlord who lives by exploiting those who cultivate his land, the rich peasant leases only part of his land and cultivates the rest himself as a true member of the peasantry. Though there were some rich peasants who as usurious moneylenders and as brutal exploiters of their tenants and agricultural laborers came close to 
being in the landlord class, in general the rich peasants could be counted on not to obstruct the revolutionary peasant movement and even to join it on such issues as abolishing feudal customs and obligations. Aidit argued that the rich peasant could be neutralized in the struggle against the landlord. ${ }^{10}$

A sympathetic role was seen for the middle peasants, whose economic independence did not as a rule bear the taint of usury or the exploitation of others and whose need to rent additional land from the landlords often put these peasants, like their poorer relatives, at the mercy of imperialists, evil landlords, and members of the bourgeoisie. Aidit expressed confidence that the middle peasants could not only become a part of the antiimperialist revolution and the agrarian revolution but could also accept socialism. Consequently they were one of the important forces pushing the revolution forward and were a reliable ally of the proletariat. He saw their attitude toward the revolution as a decisive factor for victory or defeat because the middle peasants comprised the majority in the country-side after the agrarian revolution.

But Aidit saw what he called the village semiproletariat, the poor peasants and agricultural laborers, as the largest force pushing the revolution forward. It was natural for them, he said, to be the most reliable of the allies of the proletariat and a basic part of the forces of the Indonesian revolution. The poor and middle peasants that made up the majority of the inhabitants of the villages, he averred, could only win their emancipation under the leadership of the proletariat, and the proletariat could only give leadership to the revolution if it had made a firm alliance with the poor and middle peasants.

Cadres were urged to go down into the villages, in order to become more thoroughly familiar with the social and economic - especially agrarian - conditions in the rural areas, to practice the "three withs" (work with, eat with, and sleep with the peasants), and to ascertain and translate into political slogans the specific grievances in various villages. At the Sixth National Party Congress Aidit reported:

"The movement of 'going down to the masses', implementing the 'three withs', has clarified agrarian relations for us, it has clarified the degree to which feudal survivals still dominate in the countryside. The knowledge which we have obtained by these direct means is far more valuable and creates a far deeper impression than the knowledge we could get from reading many books on the same question." 11 
Aidit's practical advice to the cadres had later expanded beyond the "three withs" to include the "four don'ts" and the "four musts". The "four don'ts" were: (1) don't stay in the house of a village exploiter, (2) don't lecture to the peasant, (3) don't harm your peasant host, and (4) don't take notes in front of the peasant. The "four musts" were: (1) apply the "three withs" fully, (2) be modest, respectful, and well-behaved and be willing to learn from the peasant, (3) know the language and acquaint yourself with the local adat, and (4) assist in solving the problems of your host, of the peasants, and of the local Party. ${ }^{12}$

Thus there was a gradual broadening of party goals in the rural areas after 1951. The Communists pressed for reform on a wide front, demanding the abrogation of exploitative colonial land laws, compulsory written tenancy agreements between landlords and tenants, security for the tenant, lower interest on loans, higher wages for agricultural laborers, nationalization of foreignowned estates, non-renewal of expired agricultural concessions and long leases, permission to squatters to continue cultivation of land technically within boundaries of estates for forest reserves, proper compensation and adequate financial assistance to squatters who must be resettled, a ban on the use of tractors on squatter-occupied land, and cancellation of colonial laws regulating the relationship between sugar estates and peasants. Many of these demands had special appeal to peasants in the plantation regions.

Nor did the PKI stop with giving political utterance to peasant grievances. As pressure on the government yielded a new decree or a new law, party workers carefully watched its implementation, using any evidence of laxness or of deliberate sabotage by "reactionary" elements among landlords and government officials to press for stronger legislation.

Another shift in party strategy became discernible after 1955 . Cadres began to concern themselves with purely agronomic problems or with research whose results were then publicized as widely as possible among the peasants - activities that encroached on some of the normal functions of the Department of Agriculture. A PKI pamphlet issued in 1955 recommended that cadres quickly undertake concrete activities in defense of the peasants' interests, such as distribution of fertilizer, seedlings, and tools at a cheap price; repair of irrigation canals; repair of fish ponds and distribution of fish eggs; establishment of cooperatives; the sinking of wells; repair of village bridges and roads; establishment of burial associations; programming of 
general education and the education of agrarian leaders; defense of peasants brought to court; and the organization of anti-illiteracy campaigns and of sports and cultural programs. ${ }^{13}$ Cadres working in the villages preached the five principles of land cultivation - "plough deeply, plant closely, (use) more fertilizer, better seeds and better irrigation" - together with such admonitions as "treat the rice fields with devotion and care, exterminate pests, improve agricultural implements". It was a sign of success, Aidit wrote in 1959, that the peasants "have full confidence in the good intentions of the Party and ... therefore joyfully welcome the Party Volunteer Brigades which are helping them work their land. ...We must form as many of these Volunteer Brigades as possible as proof that the Party is indeed genuine in its desire to unite with the peasants, and also as a means of encouraging the development of production co-operatives in the villages."

In the years between 1957 and 1962 the Indonesian government passed a considerable number of laws, decrees, and regulations meeting many of the demands which the PKI and its mass organizations had been pressing with increasing intensity. The party claimed triumph in the seizure of all Dutch plantations and other enterprises in December 1957 and the first few months of 1958. Another triumph was claimed with the abolition of the so-called "private estates" - feudal enclaves dating from the days of the East India Company and the first years of the Netherlands East Indies government. Extensive areas had been sold at that time to European and Chinese entrepreneurs by the colonial governments as a means of bolstering their treasuries. To make the offer attractive, the colonial governments gave the buyers seignorial rights over the inhabitants of their lands. These "lords" appointed village officials, set up markets, collected fees, levied taxes (as much as one-fifth of the crop or equivalent rent on land used for the raising of fruit trees or of fish in fish ponds), and requisitioned labor at will. Although the Netherlands East Indies government over the years had repurchased many of these, at the time of the transfer of sovereignty there were still close to 200 such private estates with a total area of about 32,000 hectares which the Indonesian government, under the prodding of the Communists, decided to eliminate once and for all.

Two more far-reaching laws were passed in 1960. The first of these, the Crop Sharing Law (Law No. 2/1960), was designed to regulate the landlord-tenant relationship, to protect the weak tenant against the strong landlord, and to provide the tenant with 
incentives for increasing production. Since this law went into effect, all tenancy agreements have had to be made in writing and be signed by the two parties, two witnesses (one chosen by the landlord, the other by the tenant), and the district officer, or camat. Such a contract may not cover more than three hectares per tenant and must be valid for a minimum of three years for irrigated land, five years for unirrigated land. Under this law it is the responsibility of the bupati, as head of the kabupaten, to determine the rates for the sharing of crops after deduction of expenses for cost of seed, fertilizer, cattle, and labor employed for planting and harvesting. The bupati is to take into consideration the type of crops produced, the quality of the soil, the density of population, and the obligation to pay alms (zakat). Though the bupati has considerable freedom, the law sets as guidelines a sharing of 1:1 for rice produced on sawah and 2:1 for all crops produced on unirrigated land. The PKI had originally demanded a ratio of $6: 4$ in favor of the tenants in the case of the rice crop but acceded to the argument that, given this ratio, landlords would dismiss their tenants and hire agricultural laborers to till their land, thereby forcing many poor peasants to become agricultural laborers. ${ }^{15}$

The second law, the Basic Agrarian Law (no. 5/1960), was much wider in scope, being intended in fact as the cornerstone of a whole new program of agrarian legislation. With this law the government set out to bring the agrarian situation into harmony with the philosophy of modern Indonesia, the principles of Pancasila, and the so-called Manipol-USDEK policies announced by President Sukarno in his Independence Day speech of 17 August 1959. The legislative objectives were to lay the basis for the creation of a nationally applicable legal structure for agrarian affairs, to eliminate impediments to unity and simplicity in the law, and to establish guidelines for determining the rights on land for the entire people. The new agrarian legislation was to be grounded on adat, without the dualistic character of the old laws, and to take cognizance of relevant religious law. Only in this way, it was thought, could the new legislation meet the needs of a modern society and utilize the natural resources for the benefit of the whole nation.

In line with these purposes, the Basic Agrarian Law canceled such landmarks of colonial legislation as the Agrarian Law of 1870 which had been incorporated as article 51 in the Indies Regulation of Government of 1925, the Agrarian Decree of 1870 , the various Domain declarations, and all articles of the 
Second Book of the Indonesian Civil Code concerning soil, water, and the natural resources therein. It limited hereditary proprietary rights to land (hak milik) to Indonesian citizens only, with the proviso that, in the interest of public welfare, the amount of land that could be owned by one family would be regulated in accordance with subsequent legislation. Land not subject to hak milik, e.g. state land, could be leased by Indonesian citizens or by corporate bodies established under Indonesian law and domiciled in Indonesia. Such a lease bestowed a right to temporary use (hak guna-usaha) for a period of twenty-five years, or, in the case of estates engaged in the cultivation of perennial crops (which do not begin production immediately), for thirty-five years. Provision was also made for the conversion of agricultural concessions as well as leases into a right of exploitation (hak guna-usaha) for the remaining period of the concession or long lease with a maximum of twenty years. There was, furthermore, a time limit of one year in which application could be made to the Minister of Agrarian Affairs for conversion of the old concessions and leases into the new right of exploitation. The Dutch estates taken over by the Indonesian government and managed by the Government Estates Administration (Pusat Perkebunan Negara or PPN) were affected as well as the estates held by American, British, Belgian, and French companies, and all were forced to reorganize their companies in order to qualify under the new law.

As promised, later in 1960 a law was passed regulating the size of hak milik holdings. A minimum of two hectares of either irrigated or unirrigated land became uniform through Indonesia while in recognition of the sharp contrast in population density between Java and the Outer Islands, a scale of maxima based on population densities set the maximum limit for any locality (see Table 6).

Table 6

Maximum permissible size of farm holdings (in hectares)

\begin{tabular}{lcc}
\hline $\begin{array}{l}\text { Population density per } \\
\text { square kilometer }\end{array}$ & Sawah & Land type \\
\hline Very high density (over 400) & 5 & Tegalan \\
Fairly high density (251-400) & 7.5 & 6 \\
Fairly low density (51-250) & 10 & 9 \\
Low density (50 or under) & 15 & 12 \\
\hline
\end{tabular}

Source: Law No. $56 \operatorname{Prp} / 1960$. 
A review of PKI demands and the government's legislative and executive action during the years 1958 to 1964 reveals the taut interplay between new government measures and new PKI pressures. Thus the seizure of the Dutch enterprises brought a PKI demand for nationalization. The resultant nationalization legislation was attacked for not ruling out indemnification of the former owners and for not covering other foreign estates as well. Taking full advantage of international political developments, Communist-dominated labor and youth organizations used the Congo rebellion as an excuse to take over the Belgian estates, the Malaysia issue for actions against British enterprises, and the American military presence in South Vietnam for actions against the Uniroyal and Goodyear Company rubber estates in East Sumatra and other American property. The pattern was always the same. After weeks and months of anti-Belgian, anti-British, or anti-American propaganda, labor unions and youth organizations openly violated the law to take over foreign companies. There was perfunctory condemnation of the illegality by cabinet ministers who were careful to express at the same time their full sympathy with the deep feelings of indignation on the part of laborers and youths over the Belgian actions in the Congo, the British support of Malaysia, or the American military support of South Vietnam. Shortly afterward there would be a new government order authorizing the Government Estates Administration to take over the respective plantations.

The PKI similarly used the rapidly rising cost of living, notably the soaring textile and rice prices, to keep up their pressure on the government. President Sukarno was never mentioned in antigovernment attacks, but cabinet ministers not fully sympathetic to the PKI, officials in the ministries and various government enterprises, and many army officers in managerial positions on the plantations and other nationalized enterprises came under attack regularly. The Communists considered the army their main opponent and held army officers responsible for the ban on strikes in all enterprises including the plantations, classified as vital sources of foreign exchange. Army officers and other officials in charge of estates were also accused of corruption and given the epithet, OKB (Orang Kaya Baru, Newly Rich) or sometimes OKM (Orang Kaya Mendadak, Suddenly Rich).

A subsidiary pressure was maintained by BTI, SOBSI (Sentral Organisasi Buruh Seluruh Indonesia, All-Indonesian Central Labor Organization), and Sarbupri (Sarekat Buruh Perkebunan Republik Indonesia, Indonesian Estate Workers Trade Union) 
who demanded that their representatives be included in the management of state-operated plantations in implementation of Manipol, Nasakom (acronym for nasionalis-agama-komunis; the cooperation between nationalist, religious and communist organizations), and other policy statements by President Sukarno. Every clash between the Government Estates Administration or local estates management and the Communist-led mass organizations served to intensify the clamor for such representation.

A recurrent PKI argument was that the nationalization of capitalistic enterprises had been a sham, with control vested not in the people as promised but in private property, these extracting private profits by abusing their authority in the absence of effective supervision. In a 1963 speech titled "Dare, Dare, and Dare Again" Aidit charged that the nationalized enterprises had become a burden for the state treasury because of their unproductive use of credits and continuous waste of funds. ${ }^{16}$ This arose from the corruption of the new management and the lack of proper supervision from above by competent authorities. Supervision from below, from the masses, i.e. "social control", was precluded by the bureaucratic capitalists' deliberate delay in creating enterprise councils or advisory councils where, as part of the demonstration of management, there would have been representatives of the laborers. Aidit approvingly cited Sukarno's statement in his Independence Day speech of 1961 that "production ... is the stomach of the state, and this is why the reactionaries always concentrate their sabotage on this stomach of the state". In his campaign to rid the state enterprises of "bureaucratic capitalists" Aidit suggested the "retooling" of the officials in charge of administrative, economic, and fiscal policies and he lumped together as Old Established Forces (Oldefos) all reactionary bureaucratic capitalists, landlords, bourgeois reactionaries, compradors, and members of the right-wing middle class. The "Oldefos" pay lip-service to Pancasila, the 1945 Constitution, Manipol, USDEK, Necolim, and other current political terms, Aidit noted, but really do not believe in the revolution and are not willing to apply the principle of Nasakom to the cabinet and to the management of state enterprises. By contrast, the PKI and affiliated mass organizations were easily identifiable with the Newly Emerging Forces. The struggle to transform the colonial economy into a truly national economy was seen as inextricably linked with the agrarian struggle, whose immediate goals must be implementation of the Crop Sharing Law and implementation of the Basic Agrarian Law. 
But these two laws were not the whole answer and, in a comprehensive new attack on the problem of raising agricultural production, Aidit proposed a Movement of Six Goods: (1) lower rent on land, (2) lower interest on loans, (3) higher wages for agricultural workers, (4) higher agricultural production, (5) improvement of the cultural level among the peasants, and (6) greater political consciousness among the peasants. ${ }^{17}$

Rent reduction appealed directly to nearly all peasants, a factor "of great significance in the struggle for demanding the implementation of the Basic Agrarian Law, a law which, if fully implemented on the insistence of the peasants, will constitute the realization of limited land reform" (italics added). It was equally true that by rousing the peasant masses in the movement for rent reduction - or, as the cadres were instructed, helping the peasants "throw off the burden of oppression from their shoulders" according to the principle, "the peasants emancipate themselves" - peasant pressure could also be mobilized for the consistent implementation of the Crop Sharing Law. ${ }^{18}$

Aidit skillfully linked his program for higher agricultural production with the peasants' attempt to use lands belonging to plantations and forest reserves, putting forward demands such as: "to carry out effective reafforestation, to use reserve plots and uncultivated estate lands, to raise (catch crops) on lands of the Forest Service and estates, to demand the immediate setting up of Committees of Irrigation and Councils of Agricultural Production by enlisting the participation of revolutionary mass organizations, etc." 19

The movement for higher wages, aside from its practical value in enlisting the support of agricultural workers, supplied one more issue with which to isolate and weaken the landlord.

The PKI benefited greatly from Sukarno's use of party slogans. In his Berdikari speech of 17 August 1965, for instance, Sukarno reminded his listeners: "We have rich natural resources, our people are diligent, but, so far, the fruits of their labor have been devoured by the landlords, the usurers, the ijon brokers, the middlemen, the village devils, and others". The audience needed no prompting to identify village devils whom the peasants would crush. Sukarno warned in the same speech: "I have been very patient, I have displayed the patience of a father. But there is a limit to my patience - still more, to the patience of the people! I have given sufficient opportunity to implement land reform - I even postponed the deadline - and, if necessary, I am willing to extend it another year." 
In late 1963 the Communists had begun accusing the landlords and their supporters in the ministries and in provincial and kabupaten offices of a failure to accept and implement the agrarian legislation of 1960. The Ministry of Agrarian Affairs in 1960 had estimated that a total of one million hectares might become available for redistribution among land-needy peasants from such sources as land in excess of the permissible maximum (Law No. 56 Prp 1960), land of absentee landlords, former proprietary lands, former plantation lands returned to the government in connection with the conversion of agricultural concessions and long leases into hak guna-usaha, and lands administered by the Forest Service. Referring to this estimate of the Ministry, Aidit noted in 1964: "Only one-fifth (of 1,000,000 hectares) of it has been registered. Of this one-fifth, a mere 9 percent has been distributed, while half of this 9 percent has fallen into the hands of those who are not entitled to it. Yet it has been stated that within the year 1963 the land reform based on the Basic Agrarian Law should be completed. ${ }^{20}$ Aidit's demands for "land reform courts" and for a stepping up of the implementation of the agrarian legislation were met in November 1964 by Minister of Agrarian Affairs Hermanses, who decreed the establishment of a Command for the Completion of Land Reform (Komando Penyelesaian Landreform) with the task of breaking through the barriers standing in the way of land reform implementation. The central command, consisting of the Minister himself as central commander, two deputy commanders, a chief and a deputy chief of staff, and three members, was assisted at the regional level by regional subcommands. A month before, the Ministry of Justice had announced the forthcoming establishment of land reform courts, and by December there were twelve such courts in various areas. Charged with the disposition of all land reform disputes, these courts had a judge, an official of the Department of Agrarian Affairs, and three representatives of mass peasant organizations and the National Front, intended by Sukarno as an instrument for mass-mobilization.

About a year passed between the start of this particular campaign and the creation of new offices for the solution of the new agrarian complaints. It is quite possible that these new offices would not have been established had the Communists not shifted from the speaker's platform to actual violent action in the villages in mid-1964, encouraged by "President Sukarno's appeal that the masses must also carry out 'revolutionary gymnastics' ". ${ }^{21}$ In late June 1964, clashes occurred between peasants 
and local officials and police in districts of Central and East Java, followed by protest meetings at which resolutions and petitions were passed and sent to local, provincial, and national officials, including President Sukarno and cabinet members. When Coordinating Minister for Agriculture and Agrarian Affairs Sadjarwo condemned the "arbitrary action" campaign initiated by Communist cadres, the PKI demanded his "retooling". ${ }^{22}$

Clashes spread to West Java with the so-called Indramayu Affair of October 1964. On two occasions large numbers of demonstrators carrying BTI and Pemuda Rakyat (the P.K.I. youthorganization) posters attacked state forest guards, seriously wounding seven guards in the first incident and three in the second. The arrest of thirty-five demonstrators brought new demonstrations for their release. The governor of West Java found that land hunger among peasants was in conflict with Forestry Department efforts to develop the forest resources. Sidik Kertapati, vice-chairman of BTI, charged that the land involved in the Indramayu Affair really belonged to the villagers and accused the Forest Service of having caused the incident in order to "wrest the land from the peasant". Forestry Minister Sudjarwo was more cautious in order to avoid the fury of the PKI and spoke of an acute demand for Lebensraum, at the same time promising that "the utmost wisdom" would be applied in the settlement of the issue. On 20 November 1964, the first deputy prime minister, Dr. Subandrio, met with Forestry Minister Sudjarwo and State Minister Mudjoko for a discussion of the dispute between the Forest Service and mass peasant organizations. While the ministers urged avoidance of "cracks in the unity of the progressive revolutionary forces" and called for carefully planned large-scale migrations from Java, the Central Secretariat of Peasant Organizations of the National Front criticized the government for delays in land reform, for the imprisonment of peasants and leaders of peasant organizations, and for lack of coordination between central and regional policies regarding the administration of forest reserves.

A delegation of peasants from North Lampung in South Sumatra protested in Jakarta in early November against decisions rendered by Sumatran authorities. Brigadier General Mudjoko, chairman of the Ministerial Committee on Agrarian Matters, failed to back the Sumatran officials, declaring that their decisions were "of a temporary nature and not binding". He also urged the delegation upon their return to demand the forming of a "new-style" land reform committee based on Nasakom. ${ }^{23}$ 
With the establishment of the Komando Penyclesaian Landreform and the creation of land reform courts, the PKI and the mass peasant organizations had achieved two important victories.

A Presidential Instruction (No. 022/1964) addressed to the Ministerial Committee on Agrarian Matters charged the officials concerned to prevent new illegal occupation of state lands coming under the jurisdiction of the Forest Service and the Government Estates Administration. On the other hand, disputes with squatters who had been holding land illegally for a considerable time were to be settled through individual negotiations on the basis of policies worked out with the leaders of the local peasant organizations. The Ministers of Agrarian Affairs and of Interior jointly instructed the land reform authorities to ensure the continuation of all crop-sharing agreements whose time limits had expired but made exceptions in those cases where the land was to be genuinely worked by the owner, where the cultivator had violated his obligations, or where the cultivator voluntarily refused to renew the agreement. ${ }^{24}$

Despite the various actions of the ministers concerned with agrarian affairs and their warnings against unilateral actions (aksi sepihak), agrarian disturbances involving several thousand people and resulting in the burning of houses and crops occurred in nine desa in the Banyuwangi district of East Java. Representatives of Petani and Petanu (the peasant organizations affiliated with PNI and Nahdatul Ulama (NU) respectively) had called on the leaders of the local BTI to consult with them prior to any actions designed to "bring land reform to completion" (mensukseskan landreform). The followers of the BTI, however, preferred to "go it alone" and take full credit for their revolutionary fervor. Their competitors charged that the BTI had violated the pledge, contained in the Bogor Declaration of 13 December 1964, which called for a "system of consultation and musyawarah. ... Particularly with regard to land questions, officials and peasants are obliged to musyawarah without using insinuations, intimidation, and arms". Minister Sadjarwo led a partially successful "Nasakom mission" (i.e. a mission composed of members representing PNI, $\mathrm{NU}$, and PKI) to East Java for discussions and deliberations.

By mid-1965, with all foreign enterprises by then under government control, Aidit could no longer point to foreign capitalists as the chief enemies of the Indonesian people, in particular of the peasants, and so singled out the "bureaucratic capitalists" as the new target. On the occasion of the 45th anniversary of the Party, Aidit declared: 
"The Indonesian Communist Party holds that to achieve selfreliance in economy it is necessary to emancipate the peasants, the basic productive force of the Indonesian people, from all feudalistic fetters. The peasant movement now developing throughout the country shows that the peasants are a decisive force in support of the government's progressive foreign policy, ... The emancipation of the productive forces in the rural areas makes it possible for us to put into force the principle of developing the economy with agriculture as the foundation and industry as the guiding factor. To achieve economic self-reliance it is also necessary to end the history of foreign monopoly capital in Indonesia, first of all to confiscate British and U.S. imperialist capital and to nationalize it. The other serious obstruction to economic self-reliance comes from the dominance of bureaucratic capitalist plutocracy. Since the bureaucratic capitalists had originally raked in their capital from the theft of state property and mismanagement of state-owned enterprises, the transformation of the colonialist organizations in the Indonesian economy is entirely to their disadvantage (italics added). ${ }^{25}$

Mass Peasant Organizations and the Indonesian Communist Party

The first Indonesian Peasant Congress was held in Jakarta in late November 1945 and was followed up by the founding of the Barisan Tani Indonesia. Its stated objective was the economic and social improvement of the peasants' position by freeing the peasants of the double yoke of imperialism and feudalism. ${ }^{26}$ The BTI found especially fertile ground among the discontented peasants of the former principalities of Central Java and in the sugar districts of Central and East Java where prior to the war Dutch sugar and tobacco companies and during the war Japanese Estates Control Board, or Saibai Kigyoo Kanri Koodan, had put economic and political pressure on the villagers to sign lease agreements giving the companies control over a substantial part of the land. ${ }^{27}$

Soon other peasant organizations sprang up such as RTI, or Rukun Tani Indonesia (Indonesian Peasant Union), and Sakti or Sarekat Tani Indonesia (Indonesian Peasant Association). These organizations all supported the revolution while fending for the interests of the peasants. They repeatedly negotiated with the new revolutionary government agencies, which took over from the wartime Japanese agencies concerned with agriculture and the management of plantations, and with pamong praja, the 
administrative civil service. The peasant organizations of the early days were moderate in their demands. As time went on, however, they came gradually more and more under the influence if not the control of Communists.

In January 1951, the time when D.N. Aidit assumed the leadership of the PKI, the party had links with all three peasant organizations. RTI was openly controlled by the PKI, BTI was covertly controlled, while Sakti was infiltrated. ${ }^{28}$

In July 1951 these three peasant organizations formed the FPT (Front Persatuan Tani, United Peasant Front), which became the mouthpiece of the three affiliated organizations. Early in 1953 the Communist leadership of RTI suggested a fusion of the three organizations. This suggestion, however, ran into opposition in Sakti, whose executive committee was not backed by a majority of the membership. The joint BTI and RTI congress, held in September 1953 in Bogor, approved the fusion and adopted the name BTI. A Sakti congress approved a fusion with BTI in June 1955.

Once the competition between these three peasant organizations had come to an end, BTI began to expand its membership rapidly. It claimed a membership of 800,000 in March 1954 and about 2,000,000 by April 1955. At the time of the elections at the end of 1955 the BTI secretariat reported a membership of some $3,300,000$. This remarkable growth resulted from the strenuous membership drive which the Communists conducted prior to the elections. In the next ten years BTI greatly increased its membership and by 1965 claimed no less than $8,500,000$. The bulk of the BTI membership, as one should expect, was found in Java, but there were secondary centers of concentration in both East and South Sumatra, two regions which have large Javanese communities thanks to a concentration of estate agriculture and, in the case of South Sumatra, immigration of landless Javanese who preferred a life as pioneers to one as plantation workers.

In 1965 BTI branches could be found in practically all kabupaten of Indonesia and in more than 80 percent of all kecamatan, but initially BTI concentrated its activities in parts of the country where squatters held extensive tracts of land belonging legally to estates or to forest reserves. Here the BTI cadres had an ideal field for their propaganda and with alacrity took the side of the squatter against the foreign planter as the representative of capitalism and imperialism and against an Indonesian bureaucracy which served foreign interests under the terms of the Round Table Conference Agreement. 
The aggressiveness of the BTI varied from district to district and from kecamatan to kecamatan, reflecting differences in the political sophistication and militancy of the local leaders. The quality of the BTI was of constant concern to the PKI leadership, which over the years had spent a great deal of effort on the training of the BTI leadership. This bore fruit in the party's firm hold on the peasantry and in the size of the peasant organization. The competitors of BTI - Petani, affiliated with PNI; Petanu, affiliated with NU; STII, affiliated with the Partai Sarekat Islam Indonesia (PSII) - could claim nowhere near the same strength. No other party laid as much stress on village investigations as did the PKI and its affiliated BTI. This permitted the party to make use of local social, economic, and physico-environmental conditions in its efforts to win the support of the peasantry and to give traditional village institutions a new political orientation. A high degree of flexibility characterized the work of the PKI and BTI in the rural areas, as comparison with the activities of the BTI in East Sumatra and Java showed.

Shortly after the miscarried coup of 30 September 1965, Minister of Agrarian Affairs Hermanses attempted to divest the Communist Party of its appeal among the peasants by emphasizing that land reform was not conceived by the Communist Party but was "an integrated part of our revolution, the basis of the country's over-all national development plans". He also announced the suspension of all members of the National Land Reform Committee who had been identified with the BTI. The Minister charged that the PKI had been waging a campaign to convince the peasants that only the Communist Party really promoted land reform, whereas actually his Ministry "will carry out land reform according to plan and within a set time limit". ${ }^{29}$ This statement failed to explain why the laws were being implemented at such slow pace and failed to give any information about the date set for the completion of the reforms. 


\section{CHAPTER IV}

\section{THE AGRARIAN CONTROVERSY IN SUMATERA TIMUR FROM THE TIME OF TRANSFER OF SOVEREIGNTY TO THE TANJUNGMORAWA INCIDENT}

The incorporation of the Negara Sumatera Timur into the unitary Republic of Indonesia had immediate repercussions in the agrarian struggle, by far the most profound of these stemming from the social and economic principles embodied in the new constitution. Three articles from the Constitution of 1945 had, at the insistence of Republic of Indonesia leaders, been taken over to the Provisional Constitution of 1950 which now replaced the interim Constitution of the Republic of the United States of Indonesia. In view of the great impact these three short articles were to have on subsequent developments in East Sumatra, it will be useful to set forth here their texts as promulgated in the Provisional Constitution of 1950: ${ }^{1}$

\section{Article 7}

1. All citizens have the same status before the law and in the government and shall, without exception, respect the law and the government.

2. Every citizen shall have the right to work and to expect a reasonable standard of living.

Article 18

1. The State shall be based upon the belief in God the Almighty.

2. The State shall guarantee the freedom of the people to profess and exercise their own religion.

Article 38

1. The economy shall be organized cooperatively.

2. Branches of production that are important to the State and that affect the life of most of the people shall be controlled by the State.

3. Land and water and the natural riches therein shall be controlled by the State and shall be exploited for the greatest possible welfare of the people.

It was clear from the beginning that the sharp distinction which 
the Negara Sumatera Timur had maintained between the rights of the rakyat penunggu or anak asli, the truly autochthonous population, and the rights of immigrants to the area would no longer be allowed. Article 7 of the Provisional Constitution of 1950 imposed on the East Sumatran situation the uniform treatment of all citizens - autochthonous people, Javanese, Tapanuli Batak, Chinese holding Indonesian citizenship, or any other. The squatter problem suddenly took on an entirely new dimension.

Just as radical in their implications were the new economic principles of Article 38, which provided the foundation for the Basic Agrarian Law of 1960 (see Chapter VII). Less apparent were the changes that would be brought about by Article 18. The establishment of Christian communities had long been hampered in the former self-administering territories along the coast of East Sumatra where Moslem sultans had opposed the settlement of Christian Toba Batak. ${ }^{2}$ There was not a Batak church in the sultanates of Langkat, Deli, Serdang, or Asahan prior to 1940; the church in Medan was built in 1930 on land belonging to the town of Medan and thus outside the jurisdiction of the sultanate. There was little or no room for Toba Batak in East Sumatra, except as clerks in the offices of the estates and in Medan, but certainly not for landseeking Toba Batak farmers. Simelungun was the only part of the Residency of East Sumatra that saw a large influx of Toba Batak after the second decade of the present century when the government began to encourage the immigration and settlement of land-needy Toba in the irrigation districts of Tanah Jawa and other parts of the Simelungun upland areas.

Not many Batak churches were established between 1940 and 1949 in either the coastal regions or the Simelungun upland regions, but the situation changed dramatically after December 1949. Toba Batak by the thousands began pouring from the highlands of Tapanuli as well as the upland areas of Simelungun into the coastal plains and lowlands of East Sumatra where most established themselves as squatters on estate lands.

Two months after the signing of the agreement between VicePresident Hatta and Wali Negara Mansur, the first steps were taken to incorporate East Sumatra into the Republic. On 14 July 1950 Minister of Interior Anak Agung gde Agung decreed a Preparatory Commission for the Incorporation of Sumatera Timur into the Unitary State (Panitya Persiapan Negara Kesatuan untuk Sumatera Timur or PPNKST) under the chairmanship of Sarimin Reksodihardjo. ${ }^{3}$ This commission, which included representatives of the Republic of Indonesia as well as of the Negara Sumatera 
Timur, was given to preparing a working plan for the incorporation of the Negara into the Republic. Only six days later, however, Sarimin announced his Urgency Program, under which Sumatera Timur lost its autonomy and became an administrative unit embracing the prewar residency of East Sumatra without Bengkalis. ${ }^{4}$ The parliament of the Negara was thereupon dissolved and provisional councils were set up for each of the six kabupaten of Sumatera Timur. In September 1950 Sarimin created the Committee for the Establishment of the Province of North Sumatera (Panitya Penyelenggara Pembentukan Propinsi Sumatera Utara or P4SU) assuming the chairmanship himself.

Regarding the agrarian situation, the Urgency Program called for the formulation of new principles for the determination of optimum land use, for a plan based on these principles for the reallocation of returned estate lands, and (Article IV) for a scheme to ensure public benefits from all future plantation operations. As the subsequent instructions (commonly referred to as the "Sarimin Plan") for the implementation of Article IV made clear, the PPNKST expected the estates to furnish evidence that part of their profits were going to the people in the form of technical assistance in land reclamation, drainage, and irrigation projects. $^{5}$

A special Commission for Agricultural Land Affairs (Panitya Pusat Urusan Tanah Pertanian, or PPUTP) was installed on 28 September 1950 to administer the "Sarimin Plan", with Sarimin himself as chairman, Munar Hamidjojo as vice-chairman, and fourteen other members (five from the government, six from the peasant unions, one from the labor unions, and two from planters' associations). Reporting to this Central Commission (PPUTP) were six local commissions for the six kabupaten making up the keresidenan Sumatera Timur. A series of meetings conducted by the PPUTP toward the end of 1950 resulted in general agreement between provisional authorities and the planters (the peasant and labor representatives withheld their assent) that the tobacco industry should return approximately 135,000 hectares to the provincial government and the perennial crop estates about 215,000 . The talks also established consensus for the reservation of forested areas on watersheds, along banks of rivers, and on steep hillsides, and the classification of land into such categories as land easily and inexpensively convertible into sawah and land convertible into sawah only at considerable expense. In the only major departure from earlier proposals, the PPUTP cancelled the principles of selection developed by the 
government of the Negara Sumatera Timur and established instead the rule that every adult Indonesian citizen who had resided in East Sumatra for more than six months and expressed his intent to earn his living as a cultivator had the right to apply for land. Specifically there was to be no distinction between autochthonous population and immigrants. Regarding the amount of land to be granted to land applicants, plots of two hectares of unirrigable land or one hectare of sawah were suggested, on the following conditions:

1. the land would have to be in use within three months;

2. the land would have to be cultivated by the grantee himself or with the help of his family;

3. the land could not be sold for a period of five years and could be transferred to another only with the permission of the head of the kabupaten;

4. the land would have to be used, if at all possible, for permanent cultivation (sawah, tegalan, or pekarangan), not for shifting cultivation (ladang);

5. the land would be covered initially by the right of usufruct (hak memperusahai) to be replaced later by the right of possession (hak milik).

PPUTP decided to transfer discussions to Jakarta in December 1950 in order to obtain the approval of the central government for what was called the Deli Plan, the main points of which were:

1. Government and tobacco companies agreed that an integral solution of the agrarian problem was desirable. The government, recognizing the economic value of the industry as an earner of foreign exchange and its own obligations under the terms of the Round Table Agreement, stood prepared to grant long-lease rights for 40 years, with the understanding that the industry would return 130,000 hectares to the government, retaining 120,000 hectares (which was deemed enough to permit an annual tobacco area of 16,000 hectares with a sevenyear rotation).

2. Those soils especially suited for the growing of tobacco would go to the tobacco industry, irrigable land to the government for subsequent distribution to the population, and certain parcels of land well suited both for tobacco and for sawah cultivation, to the tobacco industry or government in that order. 
3. Of the 130,000 hectares being returned to the government, it was estimated that 12,000 hectares were irrigable practically immediately, 88,000 hectares were either not irrigable or irrigable only with the help of considerable investment, and 30,000 hectares should be added to the forest reserve for hydrological reasons.

4. It was estimated that the 40,000 families then squatting on land of the tobacco estates could be given enough land to assure them a reasonable economic base but there would have to be safeguards against land speculation and some means of ensuring good land management.

5. If the experiments in which government agencies had been participating proved the feasibility of a shorter rotation period, additional land might have to be returned by the tobacco industry. ${ }^{6}$

While the PPNKST was attempting to come to grips with the agrarian problem, the number of squatters increased quite steadily, so that on 28 September 1950, Sarimin Reksodihardjo found it necessary to issue a public statement urging the peasant and labor organizations to stop their illegal invasions of estate lands because such actions, by complicating the PPUTP's efforts to implement Article IV of the Urgency Program, only delayed the improvement of economic conditions for all. It is worth noting that this announcement, in contrast to the Joint Proclamation of Tengku Mansur and Simbolon of 22 May 1950, made no reference to Ordinance 110 of 1948 against illegal squatting - an ordinance issued by the Netherlands Indies government and therefore stigmatized as a "colonial law". ${ }^{7}$ Rather than recall the ordinance, Sarimin Reksodihardjo preferred to appeal to the population.

The PPNKST limited the jurisdiction of the Bureau of Land Planning (Balai Perancang Tata Bumi), which had studied the squatter problem very closely since 1948 and had conducted a census of the squatters, by relegating it to an advisory status.

PPNKST was abolished 30 September 1950, having completed its assignment. On the same date the central government appointed Sarimin Reksodihardjo to serve as coordinator of the provincial government until a governor could be nominated. On 25 January 1951, Abdul Hakim took the oath of office as governor of North Sumatra, while Sarimin Reksodihardjo, who had played such an important role in the reshaping of the agrarian policy in East Sumatra, returned to the Agrarian Service of the Ministry of Interior in Jakarta. 
Interdepartmental discussions in Jakarta in late December 1950 and early 1951 showed that the central government approved the Deli Plan in principle but would want to reduce slightly the area to be left to the tobacco companies. On 24 March 1951, three representatives of the tobacco companies met with high officials of the Ministries of Agriculture and Interior and submitted maps showing the 125,000 hectares of land which the companies wished to retain and the 130,000 hectares to be returned. The maps too were approved in principle and the ensuing discussion revealed a far-reaching understanding between government officials and representatives of the tobacco companies. The spokesman of the Agrarian Service in the Ministry of Interior reported that a law was under consideration that would empower the central government to issue new agrarian rights for an area of 125,000 hectares on which no occupation by squatters would be permitted and squatters of long standing found on this land would be resettled. The government expected, however, that the cost of resettlement would be borne, in part at least, by the tobacco companies. The leading spokesman of the tobacco industry, after noting the industry's disappointment over earlier attempts by the local government to prevent expansion of illegal squatting, expressed confidence in the new proposal, particularly since only about 15,000 hectares of squatted land fell within the target areas requested by the companies, while another 20,000 hectares of squatter-held lands were a part of the 130,000 hectares to be returned. Thus reassured by the central government, the tobacco companies were prepared to invest new capital and to undertake further experiments toward shortening the rotation, so that at some future date additional land might be returned to the government. ${ }^{8}$

Since it was quite apparent that the proposed legislation could not be expected in the near future and that the tobacco industry urgently needed a new legal base for its activities, Minister of Interior Iskaq Tjokrohadisurjo issued a decree on 28 June $1951^{9}$ authorizing provisional measures pending the promulgation of a new agrarian law. The decree sanctioned the proposal that the tobacco companies keep 125,000 hectares for a maximum period of 30 years under conditions to be determined later and that 130,000 hectares be returned to the government. The governor of North Sumatra was instructed to decide on the geographic location of these lands within a period of three months, to which end he appointed the East Sumatran Agrarian Commission (Komisi Agraria Sumatera Timur), headed by Bupati Munar. 
The Minister of Interior also created, by a decree dated 27 June 1951, the Office for the Execution of Land Distribution (Kantor Penyelenggara Pembagian Tanah, or KPPT), which, as its name indicates, was given the extremely difficult assignment of administering the land distribution program in East Sumatra. ${ }^{10}$

The division of tobacco lands as proposed by the tobacco companies on maps submitted 24 March 1951 did not meet with the approval of Governor Hakim, who was fully aware of the popular demand for easily accessible, easily irrigable or actually irrigated land. He therefore insisted that a new map be prepared which would include, among the lands to be returned, all sawah areas as well as areas suited for wet-rice cultivation and, furthermore, strips of land with a depth of 250 meters on both sides of the major highways running across the tobacco region. In these demands he departed from the Deli Plan developed in 1950. On 28 September, before the expiration of the three-months period allowed by the Minister of Interior, Governor Hakim was able to issue a decree, ${ }^{11}$ accompanied by a map, giving the tobacco companies a right in rem (hak benda) for 125,000 hectares on conditions to be determined later by law. It stipulated specifically the return to the government of the following:

1. all existing sawah areas;

2. land on both sides of the road from Tanjungpura to Tebingtinggi via Binjai and Medan, as well as of the road from Medan to Bandarbaru to a depth of 250 meters, except for those plots on which were located houses or other buildings, canals, roads, stands of teak or bamboo - provided these plots were not yet occupied by the population;

3. lands occupied by kampongs plus a reserve area adequate for expansion during the next 30 years;

4. land bordering rivers in strips 50 meters wide and land within a 100 -meter radius of springs.

The decree, an important landmark in the postwar agrarian history, was welcomed by government and plantation circles as well as moderate peasant and labor organizations because it seemed to provide the basis for economic reconstruction. Unfortunately it met with violent opposition from the more radical organizations.

For more than 75 years, from about 1865 to 1941 , the planters had with great tenacity and remarkable success resisted every change that had threatened to affect their financial interests. 
Now, after the transfer of sovereignty, they faced a situation never experienced before. Peasants and laborers, who had not been directly represented by spokesmen out of their own ranks in any negotiations, played a critical role. While during the Negara Sumatera Timur period the prewar pattern had been maintained, the officials of the Republic, under pressure from the people and from parliament, began to insist on participation of representatives of peasant and labor unions in any negotiations which in any way affected the economic interests of these elements of society. Governor Hakim's decree stood in violation of this new policy, as did the Deli Plan and the subsequent conference in Jakarta on 24 March 1951. All these negotiations had been conducted without representation from the peasant organizations.

East Sumatra had eight peasant organizations in early 1950, which competed with each other in their efforts to win followers. The multiple development of peasant organizations had begun in November 1945 when the Republican leaders issued a call for the creation of a multiparty system in order to disprove the claim that the Republic of Indonesia wanted to establish a totalitarian system. This led to a proliferous growth not only of parties, referred to in Chapter I, but also of peasant organizations, many of which became associated with a political party or were actually set up by a political party seeking followers among peasants (see Table 7, pp. 56-57).

East Sumatra appeared to be a particularly attractive field for peasant organizations originating in Java. Some of the East Sumatran peasant unions, however, were strictly local in origin and did not spread outside its boundaries. By 1950 the leading peasant organizations were BTI or Barisan Tani Indonesia, whose leadership included Socialists, Communists and others, and which had national headquarters in Yogyakarta; RTI or Rukun Tani Indonesia, openly linked with the Communist Party; GTI or Gerakan Tani Indonesia, affiliated with the Indonesian Socialist Party; Sekata or Serikat Kaum Tani; Gaperta or Gabungan Persatuan Buruh Tani; STII or Sarekat Tani Islam Indonesia, affiliated with Masyumi, Gabungan Buruh Tani Tionghoa, representing the interests of Chinese squatters; and finally Badan Perjuangan Rakyat Penunggu (BPRP) or Council for the Struggle of the Autochthonous Population, representing the agrarian interests of the rakyat penunggu who felt seriously threatened by the policy of the Republic. ${ }^{12}$

All of these organizations, except Badan Perjuangan Rakyat 
Penunggu, insisted on equal treatment of immigrants and local population. Their emphasis on equal treatment was not only in keeping with the constitution but politically realistic, since the immigrants by far outnumbered the autochthonous inhabitants. Any party anxious to win a large following had to oppose a land policy that treated the majority of the voters of East Sumatra as second-class citizens. Such had been the policy of the discredited federalists of the Negara Sumatera Timur. The only party, apparently, prepared to support the cause of the anak asli was the National People's Party (PRN or Partai Rakyat Nasional) which, however, was strikingly unsuccessful in the territory in the 1955 elections.

Of the smaller number of other peasant organizations which sprang up in East Sumatra after 1950 - some strictly Sumatran and some as branches of nationwide organizations - the most notable was Petani, or Persatuan Tani Nasional Indonesia. Petani was affiliated with the Indonesian Nationalist Party and first appeared in East Sumatra in 1951, gaining considerable importance in subsequent years.

Peasant as well as labor unions differed greatly both as to programs and degree of militancy. In East Sumatra in 1950 the most aggressive peasant unions were BTI and RTI. STII and BPRP were by comparison so moderate and relatively law-abiding that their opponents derisively called them puppets, kaki tangan, of the planters. Aggressiveness within any one organization varied, however, depending upon the leadership, with the result that some East Sumatran chapters of a peasant organization were more moderate than their counterparts in Java. But the militants were able to influence the course of events in Sumatra Timur by sabotaging the efforts of the provincial government. Their policy of noncooperation, of deliberate violation of laws and regulations, was pursued on such a scale that the law-enforcement mechanism at times came to a standstill. Unpopular officials were intimidated by means of a barrage of attacks. Anyone attempting to enforce the law found himself accused of being "colonialminded" for taking action against peasants on the basis of laws passed during the colonial period to protect the interests and rights of foreign capital.

The Medan press, too, played an important role in the controversy over land. Papers such as Pendorong and Suara Rakjat became outlets for virulent attacks on planters as well as the provincial and central governments; Waspada, the organ of the Indonesian Nationalist Party also took an extremely hostile stand 


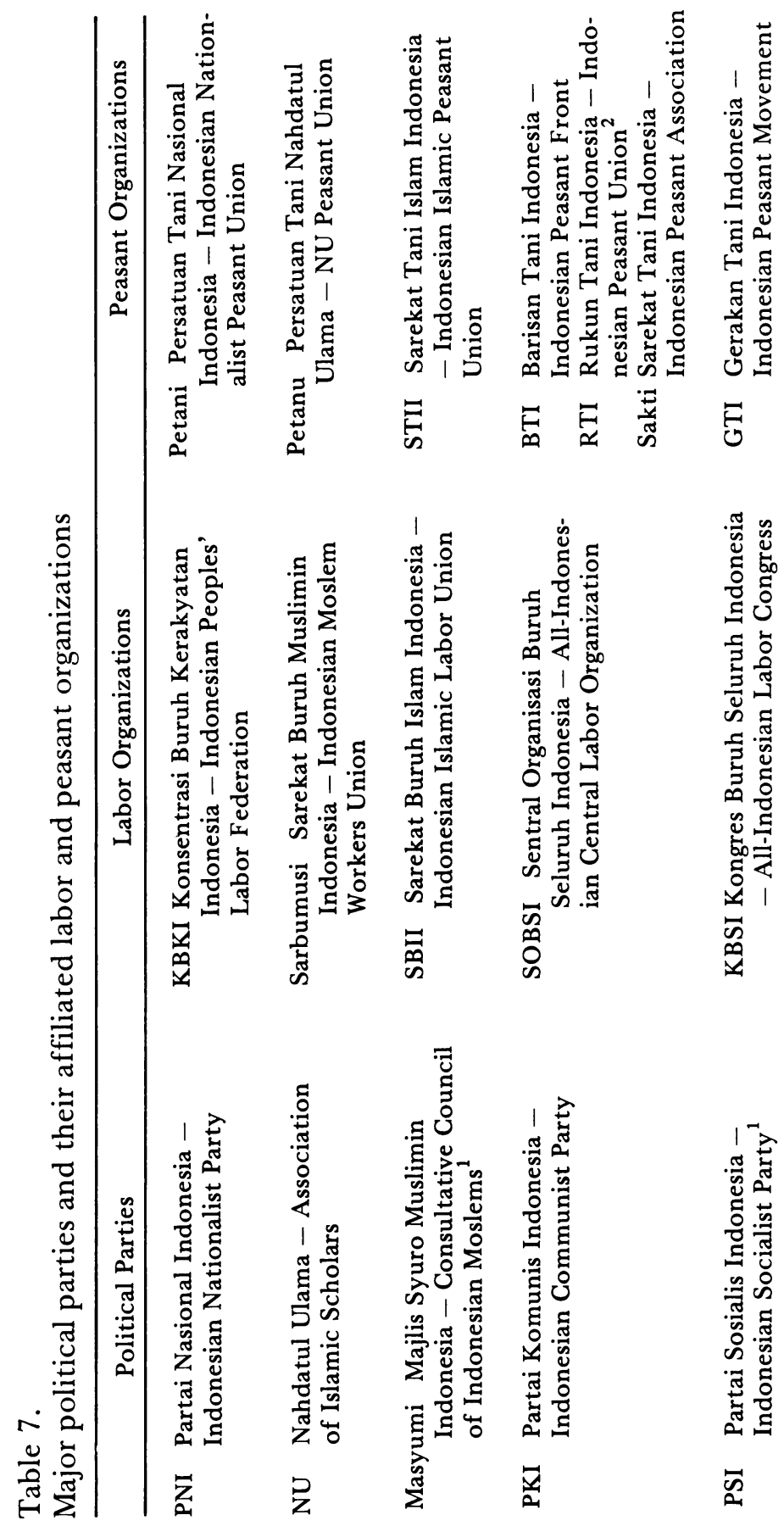




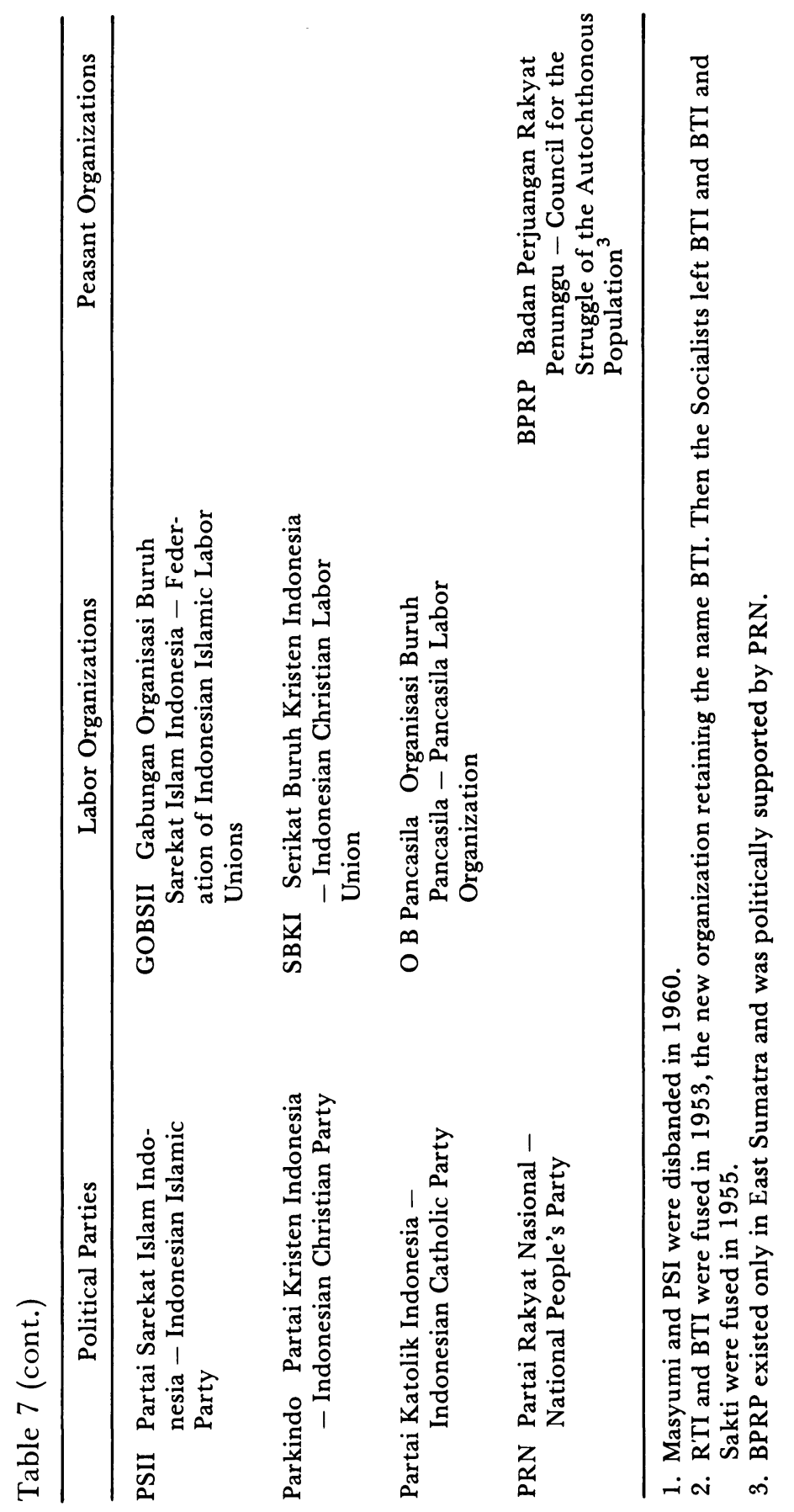


against planters and against the policy of the cabinets of Sukiman and Wilopo, which held office from 1951 to 1953. Mestika, founded by the information service of the Negara Sumatera Timur, defended the interests of the rakyat penunggu or autochthonous population. Mimbar Umum, a Masyumi paper, reflected the moderate views of the party in economic matters and defended the economic and agrarian policy of the Wilopo Cabinet.

BTI was by far the most militant peasant organization in East Sumatra in 1950, leaving nothing untried to encourage and to organize further squatting. RTI in East Sumatra was considered, by some at least, more moderate than BTI. The following summary of a report presented by the secretariat to the first RTI congress in Bandung clearly shows, however, that RTI was also a militant movement. The report starts out with the observation that:

"the Revolution of 1945 failed since it did not succeed in the overthrow of imperialism and in the establishment of a Democratic Peoples' Republic. This meant the return of foreign capital, the establishment of negara, and the creation of the Republic of the United States of Indonesia - a product of the Round Table Conference in the Hague. The United States of Indonesia is a tool serving the restoration of the old order in a new form. Foreign capital still controls Indonesia's mines, plantations, factories, land-, sea- and air-transport facilities.

The revolution failed because laborers, peasants and other oppressed segments of the population who are anti-capitalistic and anti-feudal in outlook did not clearly understand the nature and aims of the August 1945 Revolution. This revolution was not carried on by genuinely anti-imperalistic and anti-feudal groups, i.e. by peasants and laborers, since these were not organized and thus could not guide the revolution.

The current struggle of the peasants has economic, social and political aspects. The war program of the peasants calls for a weakening of the political and economic institutions of foreign capital and their ultimate elimination from Indonesia. In the political sphere the peasants aim at the eradication of autocracy in government, from the central government down to the village government, because an autocratic government is a tool serving the interests of foreign capital. The central government serves foreign interests rather than those of the people, especially peasants and laborers, by recognizing agricultural concessions and long leases. 
The old agrarian policy must be terminated. The economic aims of the peasants are: nationalization of land; land distribution among the landless; eradication of feudalism; nationalization of all foreign enterprises; increase in peasant production; rapid modernization of village economy; cheap rural credit, and the like. The political aims of the peasants are: guarantee of democratic rights of freedom of speech, assembly, press and the right to strike; creation of a democratic governmental system."13

In order to strengthen their position in negotiations with government authorities and planters' associations, BTI, RTI, Sekata, and Gabungan Buruh Tani Tionghoa formed a joint organization called Peasant Front of East Sumatra (Front Tani Sumatera Timur) in the second half of 1950.

The newly established secretariat of Petani in Medan issued a policy statement outlining a position on the land problem very similar to that of Communist-dominated peasant organizations, i.e. Petani was a nationalist peasant organization which was anticapitalistic and anti-imperialistic, dedicated to the liquidation of foreign and strengthening of national capital in Indonesia. As to concession lands, Petani maintained that the people, the legal owners, had been robbed of these lands by Dutch capitalists with the support of Dutch imperialism and that the former sultans and rajas, who had leased these lands to foreign entrepreneurs although they had no right to do so according to adat, had acted as satellites and tools of Dutch imperialism. The planters' offer to make certain lands available for peasant agriculture was an insult to the farming population of East Sumatra. In the opinion of the Petani leadership, the government should view the occupation of concession lands by peasants as an expression of their growing consciousness of their rights and should strengthen government ties with the people by guiding this effort to restore rights to the land. ${ }^{14}$

The decrees of 28 June and 28 September 1951, though regarded as reasonable by such moderate organizations as STII and BPRP, stirred a new wave of opposition among the more radical peasant organizations and newspapers. The fact that the decrees did not alter the legal foundation on which the plantation companies based their rights and operations, i.e. the planters continued on the basis either of unexpired concessions or of permission to hold expired concessions pending new agrarian legislation, ${ }^{15}$ was of little consequence if the final arrangement would involve new agrarian rights. So long as the proposed law was not 
yet passed by parliament, the radicals intended to continue pressing their attacks against the decrees.

In this the PKI and PNI and their respective peasant organizations worked closely together. About three weeks after the publication of Governor Hakim's decree the Communist Section Committee of North Sumatra issued a statement accusing provincial officials of intimidation, provocation, and terror in their arbitrary arrest of squatters and destruction by tractors of squatters' homes and crops. Provincial officials were described as "bourgeois compradors" siding with foreign capitalists at the expense of laborers and peasants, who had sacrificed so much during the struggle for independence. Although, according to calculations of the Deli Planters' Association, only about 15,000 of the 125,000 hectares to be left to the exclusive use of tobacco companies were occupied by squatters, it was flatly claimed that these 125,000 hectares were the source of livelihood of peasants who would suffer greatly, should the decree be implemented. Under the slogan "Land is the property of the peasant who tills it", all peasant organizations of East Sumatra were urged to work closely together in order to defend the squatters and to fight against the governor's program. Labor unions were called on to support the peasants in their struggle against "petit bourgeoisie, national bourgeoisie and intellectuals". ${ }^{16}$

In response to this appeal several organizations ${ }^{17}$ joined in the United Peasant Front (Front Bersama, also known as Front Persatuan Tani Komisariat Sumatera Utara) and on 1 November 1951 published a strong policy statement condemning the proposed division of old tobacco concessions between the government and the companies. Despite this opposition, Governor Hakim and the staff of KPPT went ahead with the surveying and marking of the new boundaries of the tobacco estates as well as the resettlement of all squatters found on the newly designated tobacco lands, moving as quickly as possible in order to restore law and order.

The technical execution of the land division and its distribution among resettled squatters was the responsibility of the KPPT, which could call on the Bureau of Land Planning and on the technicians - such as agronomists, soil scientists, and foresters in the Department of Agriculture for advice or assistance. As stipulated in the governor's order of 15 August $1951,{ }^{18}$ each kewedanaan had two commissions: the first consisting of the assistant wedana, technical personnel from the Departments of Agriculture and of Public Works assigned to the kewedanaan, and 
the heads of the various kampongs involved in the agrarian issue; the second of the assistant wedana plus two representatives of the specific kampong which claimed land. These two commissions discussed with a representative of the estate or estates concerned the exact boundaries separating the lands of the tobacco industry from those of the Indonesian peasants. The following assumptions and procedures, incorporated in a detailed guide with the approval of the governor on 29 December 1951 and amended on 11 February 1952, guided KPPT negotiations:

1. All Indonesians occupying estate lands were to be considered illegal squatters - even those whose occupation went back to the time of the Japanese occupation or the immediate postwar period $^{19}$ - and therefore, in principle, any squatter, on any land being resurveyed whether for return to the government or for retention by the estates, was subject to resettlement.

2. All squatters were to be screened and classified as full-time peasants, laborer-peasants (buruh-tani), or laborer-traders (buruh-saudagar).

3. Land suitable for peasant farming was to be surveyed and divided into lots of either two hectares of unirrigable land or one hectare of irrigable land for full-time peasants or twotenths of a hectare for supplemental use by the buruh-tani (laborer-peasant) and buruh-saudagar (laborer-trader) groups.

4. To ensure complete impartiality, the lots were to be distributed by means of a lottery. ${ }^{20}$

All squatters in the tobacco region were required to submit to the screening and classification process and to the vagary of a lottery.

From the squatter's point of view, the first critical feature was whether the KPPT classified him as a full-time peasant or a parttime cultivator (drawing more than Rp. 500 annual income from another occupation). The second great uncertainty was the location of his new lot. He might over the years have developed a small plot near a good road not too far from town, whereas the farmland he drew in the lottery might be located miles away in a relatively inaccessible corner. It might even be very swampy or subject to unpredictable deep flooding, or it might be located in the southern upland belt, again many miles away from good roads, from a market, and from a school for his children. There was also the financial imposition; the KPPT itself conceded that the monetary allowance of Rp. 300 was not enough to cover the 
cost of dismantling a house and of moving timber and other materials, household goods, tools, and miscellaneous belongings to the newly assigned farmstead. In addition, a squatter faced the great risk that the lottery would assign a farmlot already occupied by another person who might refuse to vacate the land. The first lottery was held in kecamatan Kwala of kabupaten Langkat on 15 March 1952.

KPPT was greatly handicapped by insufficient funds. The central government had originally budgeted Rp. 25,000,000, but the allocation was reduced to Rp. 7,000,000 and only Rp. 3,000,000 of this reduced allocation were ever provided to the provincial government. Governor Hakim, in line with Article IV of the Urgency Program, obtained a pledge of Rp. 2,000,000 from the Planters' Association to be used for the construction of village centers, churches, mosques, and other projects not financed out of governmental funds; Rp. 600,000 were paid with the promise to transfer additional funds should the central government make additional funds available.

All of these uncertainties caused resentment and opposition; however, with the firm backing of the governor, the KPPT proceeded with its work program, which had been forwarded to the Ministry of Interior in Jakarta and orally approved by Sarimin Reksodihardjo, the former chairman of PPNKST, now head of the Agrarian Service. KPPT completed the screening and registration by 1 January 1953. As Table 8 shows, 52,000 fulltime peasant cultivators were registered, together with 17,900 laborer-peasants and laborer-traders, who, according to calculations, needed altogether some 80,000 hectares of land. The leaders of the peasant unions maintained that a high percentage of the 130,000 hectares of released lands was completely unsuited for smallholder agriculture on account of steep gradients or swampy nature and that the tobacco companies had selected for their own use the best soils of East Sumatra, from the point of view of fertility as well as topography.

All during the screening and registration process, the opposition - BTI and RTI in particular - had busily encouraged new squatting. No sooner had an estate been surveyed than new illegal squatting took place. For payment of a fee, village heads would certify long-time residence dating back to the war years. Newly arrived squatters could also, again for a fee, obtain a KPPT registration card. The result was that the KPPT census was out of date even before its completion.

On the propaganda front, the peasants were being exhorted to 
Table 8

Land applicants registered by KPPT by 1 January 1953

\begin{tabular}{|c|c|c|c|c|}
\hline District & $\begin{array}{l}\text { Peasant } \\
\text { Applicants } \\
\text { for Sawah }\end{array}$ & $\begin{array}{l}\text { Peasant } \\
\text { Applicants } \\
\text { for Dry } \\
\text { Land }\end{array}$ & $\begin{array}{l}\text { Laborer- } \\
\text { Peasant } \\
\text { Applicants } \\
\text { for Dry } \\
\text { Land }\end{array}$ & Total \\
\hline Lower Deli & 8,242 & 3,056 & 11,544 & 22,842 \\
\hline Upper Deli & ,4 & 3,921 & 1,011 & 13,361 \\
\hline Lower Serdang & 6,278 & 8,451 & 1,720 & 16,449 \\
\hline Upper Serdang & - & 1,385 & - & 1,385 \\
\hline Lower Langkat & 3,47 & 113 & 138 & 3,724 \\
\hline Upper Langkat & 2,006 & 7,199 & 3,486 & 12,691 \\
\hline \multirow[t]{2}{*}{ Total Tobacco } & 28,428 & 24,125 & 17,899 & 70,452 \\
\hline & \multicolumn{4}{|c|}{ Amount of Land Required in Hectares } \\
\hline $\begin{array}{l}\text { Total Tobacco } \\
\text { Region }\end{array}$ & 28,428 & 48,250 & 3,580 & 80,258 \\
\hline
\end{tabular}

Source: Unpublished data obtained from files of Tata Bumi, Medan.

complain that the government, instead of resettling squatters to accommodate the tobacco industry, should make the tobacco companies return all squatter-occupied land. In another line of attack, BTI leaders argued that a land lottery amounted to gambling and was therefore immoral, but supporters of KPPT cited the Koran in defense of the system of land assignment by means of drawing lots. ${ }^{21}$ The BTI and RTI were also stirring the resentment of Javanese plantation laborers over their classification as buruh-tani with a right therefore to only 0.2 hectares. Such "discrimination" meant an end to any hope of climbing the agricultural ladder to the enviable status of independent farmer and in effect forced their continuation as plantation workers. ${ }^{22}$ The only answer the KPPT could make to these complaints was that the classification and resettlement had to be judged against the government's basic objective, i.e. facilitating plantation operations so as to create foreign exchange, which had been determined for the best interests of the national economy.

Somewhat less determination guided matters in the local judiciary. In March and April 1952, several groups of squatters belong- 
ing to BTI were tried in Medan court because of illegal occupation of estate land assigned to the Deli Company by decree No. 36/K/Agr. of 28 September 1951. The prosecutor asked for and the judge pronounced a very mild sentence of Rp. 10 or two days arrest. An appeal by the tani was rejected out of hand because of the lightness of the sentence. ${ }^{23}$ The planters were dismayed by this abandonment of Article I's provision for a jail sentence of up to three months or a fine of up to Rp. 500.

The fact that the governor was a Masyumi member only compounded the political dilemma of the provincial authorities charged with expelling Indonesians from the land of foreign companies for the Masyumi Party, by its support of the RTC agreement, had become the major target of the radicals. The leftist labor and peasant unions organized public demonstrations against the provincial government's activities, directed resolutions and motions to the President, his cabinet officers, and Parliament, and recruited new squatters in Tapanuli, Simelungun, and Karo for the invasion of lands from which KPPT had just moved cooperative squatters.

The Wilopo Cabinet took office on 3 April 1952 with a program calling for the restoration of estate production to prewar levels and a settlement of the agrarian conflict without detriment to the economic interests of the state. ${ }^{24}$ Wilopo insisted that the central government was allowing the provincial government ample discretion for the settlement of the agrarian conflict, but I.J. Kasimo, member of the Partai Katolik and also Chief of the Jawatan Perkebunan (Estates Service in the Department of Agriculture) explained that Governor Hakim and the KPPT were being frustrated less by any restriction of discretionary powers than by irresolute central government support of their actions in the face of serious political pressures. ${ }^{25}$

Followers of Petani refused to participate in lotteries organized by KPPT in May 1952, citing statements by two high officials of the Agrarian Service of the Ministry of Interior, who were also on the central board of Petani, at Petani conferences in Medan in March and May 1952. ${ }^{26}$ Objections were raised by provincial officials that these two Interior officers had, by their very presence at Petani conferences in Medan as well as by their statements, endorsed opposition to provincial authorities and encouraged Petani members to sabotage the efforts of KPPT to carry out the governor's instructions. The amended guide lines which were followed by KPPT had been forwarded to the Agrarian Service at Jakarta on 11 February 1952. 
Governor Hakim learned from a Medan paper on 30 May 1952 that the Ministry of Interior had suggested certain modifications of his 11 February 1952 set of instructions to KPPT. ${ }^{27}$ Not until 4 June 1952 did a letter and directive from the Ministry, both dated 28 May 1952, arrive. ${ }^{28}$ These modifications, forwarded when, according to the governor and KPPT, about 90 percent of the assignment had already been completed with the ready cooperation of the majority of the squatters, included: a limitation on resettlement to the most urgent cases; provision that in such cases the new sites be as close as possible to the old ones; assignment of swampy or forested sites only after these had been readied for occupancy; and, most controversial, an end to the category buruh-tani, since an applicant should be judged on the basis of his present activity rather than his past occupation.

Mohammad Said, chief editor of Waspada, who was close to the PNI and Petani leadership, attacked Governor Hakim and his subordinates of KPPT in a series of six articles. ${ }^{29}$ To Said, the contention of KPPT and top officials of North Sumatra that, by and large, the squatters were complying with their orders except in places where they were being misled by agitators and mischiefmakers was simply another reminder of the colonial period when Dutch officials claimed that the Indonesian people had no demands except where misled by "so-called leaders who are really troublemakers". Said then told his readers: "In reality these leaders, who are being accused, succeeded in winning freedom and independence for the people and in giving high positions to those officials, who could never have even dreamed that they should ever occupy such high positions". ${ }^{30}$ At the same time the newspaper Suara Rakjat stepped up its attacks on Governor Hakim and KPPT officials, and BTI as well as Petani urged their members to resist all further resettlement efforts and encouraged those who had already been resettled to return to their former places of abode. Meanwhile, the conservative Mestika printed a series of four apparently inspired articles in support of the provincial authorities, arguing that the suggestions in Agr. 12/4/16 of 28 May 1952 were completely impractical and hinting that PNI and Petani were after East Sumatran votes in the forthcoming elections. ${ }^{31}$

The barrage of accusations directed against officials willing to enforce the law tended to intimidate some local officials, so that the governor and the chief of KPPT had to admonish subordinate officials to show firmness in the pursuit of the resettlement program. This became especially necessary after Waspada 
prematurely published the letter of 28 May 1952. The chief of KPPT wrote on 31 May to all bupati of East Sumatra:

“... we should like to make it clear that the land distribution program must go on.

If a person refuses to draw lots, that is his own business, but if a person refuses to move to another place, I regret to say that we must enforce the law by using police force. In practice, we find that if we place two or three leading persons of the organization involved under arrest, their followers will obey regulations.

Taking the agricultural season into consideration, the squatters - in case of necessity - should be allowed to harvest their crop on their present land, but only this season's crop.

In cases where police assistance is needed it is desirable that you as bupati and head of the area take the case in your own hands; but should you not be able to solve the problem, the provincial government will take the case over."32

June, July, and August - the critical months just before the rainy season, when land must be prepared for rice planting always brought the sharpest clashes on the agrarian front and 1952 was no exception. Tensions had been building for months until on 28 August the situation came to a head with an incident on Cinta Raja Estate in the Kabupaten Langkat that became the year's most controversial case.

According to an official KPPT report, Cinta Raja Estate, belonging to a Swiss company, had been assigned land which a BTI group of squatters, under the leadership of a leader named Senan, had been farming. Government records show that this group had been given time to harvest their last crop but had been warned not to plant a new one as the land was to be turned over to the Cinta Raja Estate. On 1 August, 5 August, and 12 August, authorities notified Senan and his followers that the land would be tractored on 28 August and warned against further cultivation of estate land, but Senan told his followers to go ahead with cultivation and planting. On 27 August, the wedana of Langkat Hilir and the assistant wedana of Secanggang (in whose administrative territory the land under dispute was located) inspected the area to be tractored the following day and discovered part of the land freshly planted. Hoping to avert a direct confrontation, the bupati of Langkat, in letter No. 1957/6/U.T. of 28 August, thereupon informed Cinta Raja Estate that land already planted could not be tractored but that unplanted land could be plowed with the help of tractors. 
Police from Secanggang and Tanjungpura, as well as the assistant wedana of the kecamatan Secanggang and the kepala kampung, arrived on the land under dispute on 28 August in order to supervise the work of the tractors and to prevent any incidents. Already there were Senan and an estimated 200 BTI members busily engaged in farm work, determined to prevent the "tractoring" of "their land". The assistant wedana decided to remove Senan from the scene by taking him to his immediate superiors, the wedana and bupati in Tanjungpura, for further investigation and discussion. Before being taken away, however, Senan is reported to have admonished his followers: "Take care of your land so that it is not tractor-plowed and call for help from the BTI members of kampong Teluk Sukaramai and other kampongs". Told that the tractors would go ahead, Senan cried out: "Let us become dust, let us die now". For this incitement to violence Senan was then formally arrested, after which the tractors moved in and finished their work despite the arrival of BTI members from neighboring kampongs armed with sickles and parangs, the long heavy blade with which Indonesian farmers cut brush and clear paths through the jungle.

The assistant wedana inspected the tractor-plowed land the following day and found that some 21 banana corms had been planted on it and that about 40 persons were busily digging holes for additional planting of banana corms. Two days later, on 31 August, the BTI Branch Kampung Baru notified the assistant wedana of Secanggang by letter that Senan's friends and followers would come to Tanjungpura on 1 September to inquire about their leader, but the large crowd of BTI demonstrators that showed up to demand the release of Senan was finally dispersed without further incident by the police. Except for the quiet uprooting of the banana corms by Cinta Raja Estate employees under the supervision of the assistant wedana and several policemen on 19 September, nothing else happened until Senan's case was tried in court at Tanjungpura in November. The defense lawyer, Suhunan Hamzah, who over the years had defended many BTI members in the courts of East Sumatra, turned his plea into a political speech, which was reported fully in Pendorong of 28 and 29 November. Citing a speech by Dr. Soepomo at Gadjah Mada University on 17 February 1947 on the need for a new agrarian law which would ensure the rights of the Indonesian people, Hamzah referred to Senan as a pioneer of the Indonesian revolution: "It is true that only the accused is brought into court, but this case involves not only the accused but also all the 
other peasants who need a new law which will fit all the new needs of Indonesian society". Sentenced to eighteen months in jail, Senan appealed and the case was soon forgotten, so far as the public of East Sumatra was concerned. Practically every court in East Sumatra had had similar cases, each exploited by the BTI and other peasant unions, by their lawyers, and by that part of the press which sided with them.

The next major link in the chain of events leading to the Tanjungmorawa incident of 16 March 1953 and the ensuing resignation of the Wilopo Cabinet was the Great Peasant Congress (Konperensi Besar Kaum Tani) of 10 to 13 January 1953, organized by the Joint Secretariat of Peasant Unions (Sekretariat Bersama Organisasi Tani Untuk Memperjuangkan Tanah Sumatera Timur), the former United Peasant Front, and attended by delegations from BTI, RTI, Sakti, Sekata, Gaperta, and Gabungan Tani Tionghoa Sumatera Timur. ${ }^{33}$ The chairman of the congress was S.M. Tarigan, the leader of BTI, Sumatera Timur. The highlight of the proceedings was a fiery speech by the Communist Medan lawyer, Suhunan Hamzah. His long survey of East Sumatra's agrarian history was interspersed with virulent attacks on the cabinets of Mohammad Natsir, Sukiman, and Wilopo for their willingness to implement the Round Table Agreement and their unwillingness to nationalize all foreign plantations. Hamzah urged the peasants to resist all efforts of the planters to take back those lands which they, the peasants, had occupied under orders of the Japanese military authorities and under the 1947 authorization of the Republican Resident of East Sumatra.

Of the large number of resolutions passed by the congress, those addressed to national issues called for: speedy passage of a democratic constitution; abrogation of the Netherlands-Indonesian Union and the Round Table Agreement; the immediate return of West Irian; and cancellation of the colonial criminal code and the writing of a national criminal code which would guarantee human rights and the democratic rights enumerated in the Provisional Constitution. With regard to the East Sumatran agrarian problems the resolutions demanded: an end to the KPPT program of land distribution; and to the use of tractors to expel and intimidate peasants; an increase in the land allotment to a minimum of two hectares for every applicant; granting of the right of possession (hak milik) over land presently occupied by squatters; return to the government of all agricultural concessions that could be of benefit to the people; abolition of "feudal rights"; prosecution of planters who had by the "illegal" use of 
tractors damaged the squatters' dwellings and crops; compensation of peasants for losses due to the agrarian struggle; the early dispatch of a parliamentary commission to investigate the land issues; appointment of a state commission for settlement of the land division problem which would include representatives of peasant unions; and, finally, early dispatch of a delegation to Jakarta to press for the acceptance and implementation of these resolutions. A final special resolution expressed the congress' lack of confidence in Governor Hakim and his handling of the agrarian problem.

The congress was dominated by PKI and its front organizations BTI, SOBSI, and Pemuda Rakyat, whose spokesmen accused the leadership or organizations refusing to support the Sekretariat Bersama of betraying peasant interests. The list of "traitors" included the leaders of Geraktani, KTI, RTI (Deli-Serdang only; other RTI groups of North Sumatra supported the Sekretariat Bersama), Sakti (Simelungun), STII, and BPRP. It was insinuated that provincial authorities and planters had bribed these peasant leaders to oppose the Sekretariat Bersama. Petani was not officially represented in the Sekretariat Bersama at the time of the congress, although Petani leaders attended as individuals because its affiliation with PNI precluded support for the political aims of the Communists. Yet it shared to a considerable extent the views of BTI in agrarian matters and opposed the procedures of KPPT. Shortly after the congress Petani joined the Sekretariat Bersama.

About two weeks after the congress, a split occurred in the BTI organization in Langkat. Purnama Siregar, the leader of some 5,000 BTI refused any longer to follow directives issued by BTI headquarters in Medan and Binjai. Instead, he accepted KPPT proposals calling for a shift of Purnama's group from the estates of Padang Cermin, Padang Brahrang, and Tanjong Jatti to land released by the Deli Company from its concession Sakuda. Purnama and his followers founded a large kampong called Aman Damai (Secure Peace), to which KPPT conducted visitors with pride since they regarded it as a clear refutation of the charges made by Sekretariat Bersama.

It became apparent in February 1953 that the congress had caused further stiffening of squatter resistance against KPPT efforts in many parts of the tobacco region. One indication was the outcry over the suicide of Kasan, whom the Medan papers referred to as a victim of the land distribution policy. Tani Kasan, a Javanese squatter, had come to East Sumatra as a 
plantation laborer in 1924 and become a self-supporting peasant during the war, and, most recently, as an obedient member of RTI, had refused to draw a lot in the KPPT-organized lottery. The land he claimed to have cultivated since 1942 had, however, been surveyed by KPPT and included in the lottery. When someone else drew his land, Kasan took his own life in despair. ${ }^{34}$ Public reactions ranged from the interpellation of I.B. Manuaba, PNI-Petani member of parliament, linking the suicide of Kasan with the policy of Governor Hakim to the warning in Waspada that the governor change his policy before it was too late. ${ }^{35}$

At a Petani conference held in Medan on 8 March 1953, speakers protested against the use of the "iron monsters" which were terrifying the poor squatters into abandoning land they had cultivated for years. ${ }^{36}$ The terms pentraktoran (bulldozing or tractoring) and traktor maut (tractor of death) appeared again and again in reports of the events in East Sumatra in 1952 and 1953. Planters cautiously avoided the use of tractors on land occupied by squatters without an explicit authorization by local government authorities and preferred to have officials present during the operation. The chief of KPPT was, for example, present when Padang Brahrang Estate used a bulldozer to fill in a mile-long irrigation canal which a group of forty-five RTI squatters had dug across plantation land already scheduled to be returned to the tobacco company. The squatters had been trying to establish a fait accompli in the hope that they would be able to hold this land once it had been brought under irrigation. A Medan newspaper supporting the squatters described at great length the demonstrations which occurred and involved, among other things, the weeping wives of the squatters, who were said to have thrown themselves on the ground. ${ }^{37}$

KPPT tried to complete the resettlement program as speedily as possible but found itself confronted by a hard core of squatters organized by Petani, BTI, and RTI, who refused to be resettled by claiming that, in the absence of a new law regulating agrarian affairs in East Sumatra, KPPT had no authority to insist on resettlement of squatters in order to accommodate "colonial capitalists".

\section{The Tanjungmorawa Incident}

A common misconception among both Indonesians and foreign observers is that the incident at Tanjungmorawa took place between Indonesian peasants and Western planters. ${ }^{38}$ The quite 
different fact is that it revolved around a handful of Chinese squatters and was a show-down between the peasant unions and Indonesian authorities. At issue was the refusal of ten Chinese squatters on an area of six hectares in the kecamatan Tanjungmorawa to accept resettlement as offered by provincial authorities. The land had belonged to the Senembah Company until its release to the government in September 1951 and was part of the site chosen in April 1952 by the Agricultural Service for a small agricultural and fresh-water fisheries station. The whole immediate area, located some 24 kilometers southeast of Medan on the main highway to Lubukpakam and Tebingtinggi, had been taken over during the war by former Senembah plantation workers, mostly Chinese.

These squatters were notified in July 1952 that land near the coastal village of Pantai Cermin had been set aside for their resettlement after the December rice harvest, and on 17 December the assistant wedana of Tanjungmorawa, on one of several visits to their kampong Perdamaian (Peace), announced that each family would receive a half-hectare allotment at the new location. The planting of a new crop at Tanjungmorawa was expressly forbidden.

A more or less routine resettlement seemed likely until the assistant wedana unexpectedly received a month later a letter from the chairman of the Tanjungmorawa branch of the Chinese peasant union setting forth in behalf of the squatters their conditions for agreeing to the move. The letter, consonant with the new militancy of a peasant union congress in January in Medan and almost certainly drafted by Tarigan, Suhunan Hamzah, and other Sekretariat Bersama leaders, began by outlining the history of the squatters, from their importation by Senembah just before the end of the penal sanction in 1931 to their loyalty to the Republicans during the revolution. Along with the other 204 families on the Senembah property, these squatters had been cultivating their fields there ever since the war and, though willing to comply with the government's request, felt justified in demanding that:

1. their new land be suitable for wet-rice and vegetable cultivation;

2. the land be within five kilometers of a market town;

3. the land be ready for immediate planting;

4. each family be assigned a minimum of one hectare of irrigable land; 
5. shelters and a school be provided by the government;

6. time be allowed for harvesting any crops from Tanjungmorawa;

7. the government pay all resettlement costs; and

8. food rations be distributed to each family for the first three months after resettlement.

However reasonable the conditions on humane and to some degree purely objective grounds, KPPT officials rejected the proposition in the realization that the precedents set would wreck the resettlement program. Not only did their demands go far beyond the central government's guidelines as to cost but these particular squatters were not even Indonesian citizens. To ease the situation if possible, the assistant wedana met with the secretary and the local spokesman of the peasant union on 4 February and offered the Chinese squatters alternate land near the kampong of Tajukanraga. Three days later the squatters were notified that the provincial Agricultural Service would take possession of the Tanjungmorawa site on 15 February. The Chinese squatters waited unperturbed until 18 February to go inspect the Tajukanraga land, which was thereupon refused for being unfertile and too far from a market town (seven kilometers from Tanjungmorawa). With mounting exasperation the assistant wedana took the chief of police to the site on $5 \mathrm{March}$ and tried once more to persuade the ten Chinese families to move. It was useless. The natural tenacity of these squatters was being constantly and powerfully bolstered by the leaders of Sekretariat Bersama, who had finally found the perfect instruments for their political war with Hakim.

Word spread quickly and by the time the police arrived with a tractor on Saturday 14 March ready to clear the site for the Agricultural Service a sizable crowd of squatters and agitators from the peasant union and BTI had assembled there. Outnumbered, and sensing the crowd's defiant mood, police and Indonesian authorities decided to postpone the operation for two days until a larger police force could be called and, hopefully, the crowd would have thinned. The tractor was left by the road under 24-hour guard. But, far from dispersing, the crowd grew as union leaders maintained an air of crisis and kept the people together by feeding everybody from a field kitchen. There were nearly 1,500 milling demonstrators on hand to greet the 60 policemen who came on Monday 16 March with the wedana of Lower Serdang, the assistant wedana of Tanjungmorawa, and the 
Tanjungmorawa chief of police. It was no time for retreat and officials resolutely ordered the tractor moved to the site, at which point the crowd rushed forward. ${ }^{39}$ Accounts of the ensuing mêlée were never fully reconciled but the police reported that demonstrators, undeterred by warning shots fired into the air, pulled one policeman to the ground and began grappling for his automatic rifle. Either accidentally or by a defense reflex of the policeman (no one is certain) the trigger was touched and some forty bullets sprayed into the crowd killing four Chinese and one Indonesian and wounding seventeen others. ${ }^{40}$

The Sekretariat Bersama had its cause célèbre. Medan newspapers seized the opportunity to step up their campaign against Governor Hakim and the KPPT program, playing down the fact that the incident was caused by aliens who had refused to obey government orders and had thereby blocked the work of the provincial agricultural service. Left-wing elements in PNI and the Communists, in particular, used the Tanjungmorawa incident as an excuse to attack the whole agrarian policy of the central government. On 17 March, the Communist Party of North Sumatra sent out the battle cry "Peasants Unite for the Defense of Your Land" (Bersatu Mempertahankan Tanah Kaum Tani). A few days later the Ministry of Interior dispatched a group of investigators to Medan, and the embassy of the Chinese People's Republic sent one of its consular officers. In Parliament, Sidik Kertapati, who was also chairman of Sakti, S. Sardjono of BTI, and Munaba of Petani formally interpellated the Minister of the Department of Interior about his agrarian policy and about the activities of the "autocratic" provincial governor. ${ }^{41}$ To stir up popular support, a total of twenty-two organizations participated in a Medan meeting on 23 March at which it was decided to push for an end to all use of tractors to force squatters off their land, the establishment of a state committee with peasant union representation for the study of the agrarian problem, and release of all those arrested at Tanjungmorawa.

Bowing to these pressures, Parliament appointed a five-member committee, the Committee for the Investigation of the Tanjungmorawa Affair and Land Distribution in East Sumatra (Panitya Peninjau Persoalan Peristiwa Tanjung Morawa dan Pembagian Tanah di Sumatera Timur), ${ }^{42}$ which began its work in late March. The questioning of officials directly involved in the incident as well as officials in Medan, examination of the procedures of KPPT, and visits to Perdamaian, Tanjungmorawa, Secanggang, and other sites of agrarian clashes to talk with local peasants, 
continued through April. The peasant organizations, especially BTI, instructed their members in advance of the committee's visits as to the line they were to follow. Police authorities seized documents in Tanjungmorawa which showed that the headquarters of the Communist party for Deli-Serdang urged party workers to prepare posters and banners publicizing the demands of the peasant unions, e.g. "The Tractoring of Land on which Peasants Depend to Be Stopped" (Pentraktoran Atas Tanah Garapan Tani Minta Diberhentikan). ${ }^{43}$

The Communists tried to create the impression among members of the investigating committee that the peasants of East Sumatra were overwhelmingly against the policy of Governor Hakim and the work of KPPT, but in this they failed. There was no disguising the fact that at committee hearings held on 31 March for the spokesmen of all peasant organizations of East Sumatra the Sekretariat Bersama did not even speak for all BTI and RTI groups. BTI of Langkat Hulu under Purnama Siregar and RTI of Deli-Serdang under the leadership of Mohammad Rasjid had openly broken away from their respective parent organizations. Worse still, a group representing Geraktani, STII, KTI, BTI of Langkat Hulu, and RTI of Deli-Serdang appeared to express their confidence in Governor Hakim and their support of the KPPT program in direct contradiction of the Sekretariat Bersama position. The same group submitted a joint statement to Minister Roem reiterating its support of the KPPT program and requesting the central government to approve the continuation of the KPPT land distribution program, to leave the land problem to provincial authorities, to provide rural credit, and to replace the colonial agrarian law as speedily as possible with a new national agrarian law in keeping with the constitution and favoring the common people. ${ }^{44}$

From the governor, but particularly from the officials in KPPT, the parliamentary committee received a great deal of information regarding the partition of land between estates and government, the distribution of land among squatters, and the resettlement of squatters who found themselves on land assigned to the tobacco estates. It became quite clear to the committee that the partition into estate and government land had been left to the technical services of the tobacco companies, except for the inclusion of land along the main highway and along rivers, on which the governor had insisted. The bulk of the area which the tobacco companies had made available for peasant agriculture was in the upland region well to the south of the line Binjai-Medan-Tanjung- 
morawa and involved land which had suffered badly from erosion during the few times that it had been used for tobacco cultivation. Most of the southern concession lands had not been used for twenty-five to thirty years and would not be used for tobacco cultivation again even if the companies were to be permitted to retain all concessions. A non-continuous belt of land near the coast had been released because of drainage problems.

Officials of the Department of Agriculture informed the committee that, according to their estimates, no less than 45,000 hectares or about 35 percent of the released land were unsuited for peasant agriculture on account of the land's gradient. Of the other 85,000 hectares, 45,000 were suited for farming, but since this land was either forest-covered or swampy, it needed considerable improvement in the form of land clearing, drainage, dyking, and irrigation. This would require several years of intensive work under the guidance of qualified technicians and, above all, a far larger budget than was available to KPPT. The remaining 40,000 hectares were good agricultural land ready for use, but 20,000 were needed for the expansion of existing settlements, i.e. towns and villages, so that only 20,000 hectares remained which could be assigned to squatters for agricultural use.

A much higher percentage of the land which the tobacco companies had selected for their own use was well suited for the tobacco industry than of the land released for peasant agriculture. This was indeed not denied by the planters who, however, maintained that it was plainly impossible to keep the wrapper tobacco industry alive and at the same time give all people crowded into the tobacco region an opportunity to become independent farmers by giving them one or much less two hectares of land within the greatly contracted tobacco belt. They stressed further that it would harm the economy of Indonesia if soils especially well suited for the production of high-quality wrapper tobacco were to be turned over to the production of subsistence crops by peasants who could earn more by working as estate workers in the tobacco industry than by cultivating their own small plots, not to mention the financial benefits which the state derived from the plantations in contrast to subsistence peasant agriculture. The planters also did not agree with the pessimistic views of provincial agricultural officials on the low value of the upland soils, pointing out that in fact extensive areas were well suited for such perennial crops as rubber, oilpalm, and fruit trees, provided proper soil conservation 
measures were taken. The coastal belt, furthermore, contained thousands of hectares of potential rice land requiring only dyking and the construction of automatic tidal sluices. The funds needed for this kind of land reclamation could come out of the taxes collected from the tobacco companies over a period of a few years. Such coastal lowlands had in several instances been successfully reclaimed, although one or two of these projects had been so badly neglected during the war and immediate postwar years as to necessitate their abandonment. Wherever feasible, these prewar projects, which would not require a new timeconsuming survey, should be rehabilitated before any other projects were initiated.

Mohamad Roem, Minister of Interior, strongly defended the governor for his implementation of the agrarian policy developed by the two previous cabinets and adopted by the Wilopo Cabinet as its own policy. In a lengthy explanation of the provincial government's efforts to create a self-reliant peasantry in East Sumatra, he admitted that lack of funds had prevented the central government from furnishing adequate financial support. By April 1953 not even one-third of the Rp. 25,000,000 originally budgeted had been transferred to the province; the tobacco companies, in turn, had made only about one-third of their promised contribution available. Although according to Medan the KPPT had claimed completion of 90 percent of the program, the figures given by the minister told a different story. A total of 66,500 families were screened and declared eligible for land allotment, of which roughly 39,000 families had to be resettled. By the end of April 1953 a total of 35,054 heads of households had been summoned to participate in a land drawing, with all but 7,326 persons having done so. Only 16,322 families had actually been resettled, however, leaving 11,406 reassigned families still to be moved. Table 9 gives a further breakdown of the data by major political subdivisions. It turned out that the KPPT claim of 90 percent completion applied only to the first phase of the distribution program, i.e. the calling up of eligible land applicants to participate in lotteries.

Despite the fact that three members of the investigating committee defended Governor Hakim and the policy of the Wilopo Cabinet, and despite the firm stand taken by Minister of Interior Roem, Sidik Kertapati, one of the original interpellants, on 22 May presented a motion of censure which was co-signed by Sardjono of BTI and Ahem Erningpradja of Petani, both of whom had been members of the investigating committee, and 
Table 9

Land distribution program of KPPT in Serdang, Deli and Langkat, May 1953

\begin{tabular}{|c|c|c|c|c|c|c|c|}
\hline Category & Total & $\begin{array}{l}\text { Deli } \\
\text { Hilir }\end{array}$ & $\begin{array}{l}\text { Deli } \\
\text { Hulu }\end{array}$ & $\begin{array}{l}\text { Ser- } \\
\text { dang } \\
\text { Hilir }\end{array}$ & $\begin{array}{l}\text { Ser- } \\
\text { dang } \\
\text { Hulu }\end{array}$ & $\begin{array}{l}\text { Lang- } \\
\text { kat } \\
\text { Hilir }\end{array}$ & $\begin{array}{l}\text { Lang- } \\
\text { kat } \\
\text { Hulu }\end{array}$ \\
\hline \multicolumn{8}{|l|}{$\begin{array}{l}\text { Number of families screen- } \\
\text { ed for land allocation: }\end{array}$} \\
\hline $\begin{array}{l}\text { Indonesians } \\
\text { Chinese }\end{array}$ & $\begin{array}{r}64,253^{1} \\
2,337^{1}\end{array}$ & $\begin{array}{r}21,373 \\
1,469\end{array}$ & $\begin{array}{r}8,530 \\
62\end{array}$ & $\begin{array}{r}15,842 \\
806\end{array}$ & 2,211 & 3,606 & 12,691 \\
\hline $\begin{array}{l}\text { Number of heads of house- } \\
\text { holds summoned to land }\end{array}$ & & & & & & & \\
\hline & 35,054 & 12,608 & 2,959 & 6,176 & 2,211 & 3,606 & 7,494 \\
\hline & 27,728 & 10,702 & 2,746 & 4,225 & 1,835 & 3,001 & 5,219 \\
\hline $\begin{array}{l}\text { summons } \\
\text { Number of households }\end{array}$ & 7,326 & 1,906 & 213 & 1,951 & 376 & 605 & 2,275 \\
\hline & 12,520 & 4,014 & 1,176 & 701 & 976 & 1,747 & 3,906 \\
\hline $\begin{array}{l}\text { Number of households } \\
\text { resettled in April } 1953 \\
\text { Number of households }\end{array}$ & 3,802 & 386 & 219 & 2,108 & 69 & - & 1,020 \\
\hline $\begin{array}{l}\text { to move in May } 1953 \\
\text { Number of households } \\
\text { which indicated readines }\end{array}$ & 2,369 & 692 & 132 & 690 & - & 562 & 293 \\
\hline $\begin{array}{l}\text { to move } \\
\text { Number of households } \\
\text { which have not yet }\end{array}$ & 5,318 & 2,077 & 1,219 & 726 & 790 & 506 & - \\
\hline indicated readiness to move & 3,719 & 3,533 & - & - & - & 186 & - \\
\hline
\end{tabular}

1 Of the total of 66,590 families about 39,000 were to be resettled since they were squatting on land to be kept by tobacco companies. Unpublished data prepared by the KPPT, 11 May 1953.

other members of parliament. The signers asked parliament to vote in favor of a motion requiring the Minister of Interior:

1. to suspend the distribution of concession lands in East Sumatra;

2. to cancel the KPPT instructions regarding land distribution;

3. to revise the mapping of concession lands undertaken by the Deli Planters' Association;

4. to appoint a committee, including representatives of the various peasant organizations, for the drafting of a new landdistribution program; and

5. to release as soon as possible all persons under arrest in connection with agrarian problems and to avoid future arrests. 
PNI, which had the same number of cabinet posts as did Masyumi, came under great pressure when its North Sumatra branch threatened to leave the party should the parliamentary group fail to support the Sidik Kertapati motion. The PNI executive committee attempted a compromise by suggesting that Mohamad Roem leave the Wilopo Cabinet in return for continued PNI support of the cabinet. This was rejected by Masyumi so that finally, on 2 June 1953, Premier Wilopo handed in the resignation of his cabinet rather than reply to the debate which had preceded the motion and to face the final vote on the Sidik Kertapati motion. In his letter to the chairman of parliament Wilopo stated pointedly that the cabinet might have been able to continue working together but that the cabinet could no longer count on sufficient support from the parties in the coalition. This was directed against those PNI members who clearly sided with the Communists and Communist-directed peasant and labor unions.

As Feith had shown in his study of the Wilopo Cabinet, the Masyumi-PNI coalition was subjected to many serious strains in the course of the fourteen months of its duration. ${ }^{45}$ Masyumi was not able to win PNI support of its plan to return the North Sumatran oil fields to the Shell Oil Company, nor did it succeed in obtaining PNI support for an agrarian program developed by a Masyumi minister. By June 1953 it was apparent that Masyumi and PNI were so far apart that it was impossible for them again to form a coalition cabinet. It took almost two months and five attempts to put together a new cabinet, headed by Ali Sastroamidjojo of PNI. Masyumi did not enter this cabinet but joined the opposition.

\section{East Sumatran Reaction to the Fall of the Wilopo Cabinet}

Following the resignation of the Wilopo Cabinet, the great debate round the agrarian problem continued in East Sumatra as well as in Java. The demissionary minister still adhered to his stand and supported the provincial authorities in their reasoning that since the program was based on valid decrees of 28 June and 28 September 1951 it had to be continued so long as the decrees were not withdrawn. The Sidik Kertapati motion, not having been put to a vote, thus did not alter the situation.

A steady flow of spontaneously drafted or officially inspired resolutions reached the desks of President Sukarno during June, July, and August 1953, of the chairman of parliament, of the 
parliamentary groups of parties concerned, and of the interested ministers of the demissionary cabinet urging a continuation of the land-distribution program, protesting the Sidik Kertapati motion, and expressing the satisfaction of peasant groups with the land issued to them and their hope that they would not be resettled once more. Such communications came from peasant organizations, from inhabitants of newly established villages, and from the opposition too. Adding to the uproar, the Sekretariat Bersama organized demonstrations to protest continuation of the resettlement program. It was no coincidence that, just at the time when the newly formed cabinet of Ali Sastroamidjojo presented its program to parliament, there was a demonstration at the bupati office in Binjai, Langkat against the KPPT by several hundred peasants. Their protest, over an attempt to resettle twenty-eight families, became so violent that police had to use fire arms and killed one demonstrator. This incident again was used by PKI, SOBSI, BTI, and other peasant unions following Communist leadership to press their drive against Governor Hakim.

The 25 August 1953 policy statement of the Ali Cabinet called for the appointment of a state commission in which planters and peasant organizations were to be equally represented. Its task was to investigate the possibility of developing a better land division program while guarding both peoples' - and the state's - interests. The following recommendations were proposed for study:

1. that land forming a part of tobacco concessions but on which kampongs had been built in a planned manner before 1950, or on which sawah had been laid out, should be taken out of the respective concessions;

2. that some way be found to improve desa-development work;

3. that dates of resettlement be fixed only after a harvest was completed;

4. that resettled squatters whose previous land is not immediately utilized by the tobacco industry be given the opportunity to harvest crops left behind on the vacated land;

5. that no swampy or raviney land be assigned to land applicants;

6. that within the financial ability of the state the squatters should be given: agricultural implements in addition to Rp. 300; improved transport and moving facilities; and land in a better state of preparation;

7. that all who previously were classified as buruh-tani be in- 
cluded in the category of tani;

8. that land be given only to Indonesian citizens; and

9. that mapping and division of land be reinvestigated with the proviso that the size of the area to be released by the concessionaries will not be changed or, if this is impossible, that the government be empowered to enter into a new agreement regarding the total amount of land to be returned.

As to resettlement of squatters, the cabinet ordered the transfer of only those who had voluntarily agreed to accept the land offered to them and who had not yet been moved because of unharvested crops on their squatted land. Squatters not willing to accept new land were to be left undisturbed until the government had come to a final decision on the basis of the state commission's recommendations. This latter provision in effect gave squatters the privilege of challenging a government decree and put a stamp of approval on the antigovernment actions of radical peasant unions. The degree to which the cabinet was prepared to meet the demands of the parties and mass organizations behind the Sidik Kertapati motion in return for political support was also evident in the fact that the cabinet, rather than simply indicating the problems to be investigated by the commission, suggested certain solutions. Then on 28 August 1953 - possibly in response to the Binjai incident 25 August 1953 - the new Minister of Interior issued a ban on the use of tractors for the demolition of squatter huts and the plowing of land under agrarian dispute, thereby handing the leftist organizations a complete victory. A further concession to the radical peasant unions came with the separation of the Agrarian Service from the Ministry of Interior and the creation of a separate Ministry of Agrarian Affairs inasmuch as high officials of the Agrarian Service were on the board of directors of Petani, the organization which, despite its affiliation with PNI, worked closely with PKI, BTI, and other groups pursuing a Communist-inspired agrarian program. Nothing could suit peasant organizations and their supporters better than the establishment of a separate department handling agrarian matters exclusively.

During a visit of the new minister of the Department of Interior to Sumatera Timur at the end of August 1953, the battle for and against Governor Hakim and the KPPT program reached new heights. Minister Hazairin, a member of Partai Indonesia Raya - one of the coalition parties in the Ali Sastroamidjojo Cabinet - on several occasions expressed his strong dis- 
approval of the attacks on the governor, and thus on government, and his great distrust of the radicals' motives - he spoke of slander, prejudice, lack of understanding, and deliberate exaggeration - and stressed that the resettlement program was nevertheless nearing completion. Yet despite this central government backing and the renewed rally of peasant unions who supported the provincial program - they had by now formed a coordinating body, Badan Kerja Sama Organisasi Tani Sumatera Timur or BKOTSU - Governor Hakim was replaced by Governor Amin in October 1953. By their skillful political exploitation of the agrarian struggle, overtly manifested in the Secanggang, Binjai, and Tanjungmorawa incidents, the radical groups opposing the economic and political implications of the Round Table Agreement of 1949 had nullified decrees of 28 June and 28 September 1951 and robbed the tobacco industry of any provisional security pending a new agrarian law. Although the KPPT had succeeded in removing many squatters from the target areas of the tobacco industry, Petani, BTI, and other peasant groups organized new invasions of tobacco estates in late 1953 and 1954 either by leading resettled squatters back onto estate lands or by recruiting new squatters in Sumatera Timur as well as in Tapanuli, thus undoing a great deal of the work of KPPT during Abdul Hakim's governorship. This greatly reduced the confidence of the planters in promises by the Indonesian government and led the managements of companies controlling estates devoted to the cultivation of perennial crops to see in the experience of the tobacco industry an excuse for not going ahead with a program of officially releasing a part of their concessions. Little or nothing could be done to stabilize and guide the development of peasant agriculture among people who were occupying land claimed by perennial-crop estates; tobacco estates had to be closed and laborers dismissed because squatting reached such proportions that it was no longer possible to maintain the rotation system. Declining tobacco production meant a concomitant reduction in the earning of foreign exchange so badly needed by Indonesia.

All of this was realized by many government officials and the political leaders of such parties as Masyumi, PSI, and others of similar orientation and moderation, but they were unable to oppose the political agitation created by the PNI. The fate of Governor Hakim, who was completely sidetracked, served as warning to other officials not to expose themselves to the charge of being "colonial-minded" and serving the interests of foreign 
capital, even when the orders of the central government were to call for firm action.

The planters looked with apprehension toward the future knowing that the forthcoming state commission would include certain officials of the former Agrarian Service now raised to the status of a separate department of Agrarian Affairs as well as representatives of peasant unions. 


\section{CHAPTER V}

\section{THE FIRST ALI SASTROAMIDJOJO CABINET AND THE STATE COMMISSION FOR THE DIVISION OF ESTATE LANDS IN EAST SUMATRA (1953-1954)}

In presenting his program to Parliament on 25 August 1953, Prime Minister Ali Sastroamidjojo promised to have a new state commission investigate the critical East Sumatra agrarian problem which had brought down the Wilopo Cabinet and to report its recommendations to the cabinet within two months; questions raised by Masyumi member M. Yunan Nasution as to whether the government needed another investigation so soon or had in fact studied the Ministry of Interior's report of the Djanu Ismadi team's survey in Medan in March 1953 were brushed aside. On 27 August Sastroamidjojo issued a new standfast on squatting and banned the further use of tractors to raze squatter huts or plow squatter-occupied land.

Despite the air of urgency in Sastroamidjojo's promise of recommendations within two months, it was over a month before the cabinet, at its meeting on 6 October 1953, approved the appointment of the State Commission for the Division of Estate Lands in East Sumatra (Panitya Negara Urusan Pembagian Tanah Perkebunan Sumatera Timur). As authorized by presidential decree No. 195/1953, the commission was to have fifteen members and to be divided into two sections. Three government officials (a representative of the Department of Interior, to serve as chairman; a representative of the newly created Department of Agrarian Affairs, as vice-chairman; and a representative of the Department of Agriculture, as member-at-large) were to sit in both sections. The other twelve members were to be divided equally between the two sections, so that functionally each section had nine members. Section I's six non-government representatives were drawn three each from the peasant unions and estate management; Section II's exclusively from the peasant unions. Another five months passed before the actual appointments of these fifteen members and two secretaries were made by presidential decree (No. 63/1954, dated 9 March 1954, and No. 84/1954, dated 27 March 1954). ${ }^{1}$ On 10 March 1954 the 
Minister of Agrarian Affairs formally installed the state commission in Medan and furnished it with his directives dated 5 March 1954. Thus the first meeting of the commission that was to have completed its report on the agrarian crisis in East Sumatra within two months did not take place until six months after Prime Minister Ali Sastroamidjojo promised its formation.

\section{The Ministerial Directive}

Far from being allowed a free hand, the state commission was bound by the Minister of Agrarian Affairs' detailed instructions for the handling of the land problem and for the treatment of the squatters. In these instructions it was taken for granted that the tobacco industry was to remain in control of 125,000 hectares, as agreed upon in 1951 and sanctioned by ministerial decree No. Agr. 12/5/14 of 28 June 1951 as well as by Governor Hakim's decree No. 36/K/Agr. of 28 September 1951, but a reexamination of the land partition was ordered. This review was in response to demands by peasant leaders, who maintained that the bulk of the land the companies designated for return to the government was highly marginal and no longer of any interest for their operations, that the company surveyors alone had prepared the original map of partition of the concessions, and that the companies were reserving all the good land for themselves. In fact, the peasant leaders complained, most of the land being offered was on estates which had been closed in the 1920s and 1930 s, so that the fields had reverted to jungle, estate roads were covered by second-growth forest, bridges had collapsed, and estate buildings had been demolished. Such land could be made cultivable again only by a long process of reclearing.

It is an irrefutable geographic fact that the choice tobacco lands are located in the intermediate zone between the coastal lowlands and the foothills of the hilly zones to the south. The urban centers of Medan and Binjai lie in the midst of the coveted belt containing all the "target areas" (wensarealen) of the tobacco planters. The major roads traverse the same belt. And it was precisely here, not in the forested lands of tobacco estates which had been abandoned twenty or thirty years ago, that the squatters wanted to be. The closer to Medan and the closer to a major highway - especially the highway running parallel to the coast through Langkat, Deli, and Serdang - the stronger the attraction.

As to perennial-crop estates, the ministerial directive indicated 
that the government expected a return of one third of the land, but no further guidelines could be given because no map had been submitted. Although AVROS (Algemeene Vereeniging van Rubberplanters ter Oostkust van Sumatra, or General Association of Rubberplanters on Sumatra's East Coast) had confidential maps from all its members showing proposed partitions, the directors were withholding the information from the government in view of the sad experience of the tobacco plantation companies.

The Minister of Agrarian Affairs went ahead nevertheless to stress the principles the state commission should follow in making recommendations on any land partition. First, all land clearly being utilized by the estates should, in the absence of an overriding public interest, remain with the estates. Even the consideration of public interest was to be dropped wherever the estates had erected offices, factories, sheds (the fermentation, sorting, and packing sheds of the tobacco industry), company villages for estate laborers, and the like. But the estates should in principle be asked to relinquish land along major public highways not being permanently used by the estates as well as land on which the local people had constructed permanent dwellings. Land converted into sawah before 1950 was also to be excised from the estates. On the salient matter of future peasant needs, however, there was only a vague suggestion that in the process of the land partition the population growth of the next fifty years be taken into account and adequate reserves set aside. The Minister avoided giving any hint as to whether this meant reserves for a normal population growth or for a highly accelerated one caused by the heavy influx of land seekers being directed to East Sumatra by political parties and their affiliated peasant unions. The planters objected especially to the reference to a shortening of the eight-year rotation and to the Minister's suggestion that the tobacco industry be required to conduct research to this end.

Part II of the ministerial directives dealt with land distribution to the autochthonous (rakyat penunggu) as well as the immigrant population and was therefore of special concern for the peasant union representatives of Section II. Here, distribution of either swampy of deeply dissected steep terrain was ruled out, though the Minister also called for a study of the possibility of future land reclamation and development. Appeasement of the militant peasant leaders was even more pronounced in such instructions as that resettlement of squatters should be kept to a minimum and ordered only when necessary; that, if relocation was unavoidable, 
squatters should be sent only to places not too far from their present place of abode; and that no relocation should be undertaken before the new sites were prepared so that crops could be planted and huts erected without great expenditure of time and effort. Responding to the demands of the hard core of squatters who refused even to participate in a land lottery, the Minister authorized the postponement of any relocation of these people until after the cabinet would have acted on the state commission's findings and recommendations. All this understandably distressed the planters, but the most alarming instruction proposed an inquiry into possible financial contributions by the planters to resettlement projects. ${ }^{2}$

\section{The State Commission's Procedure}

Basic elements of the working procedure adopted were formal meetings (both plenary and sectional), informal exploratory discussions among individual members, visits to plantations or other relevant places to familiarize members with actual conditions, consultations with the governor and the heads of technical services involved in the agrarian problem, and, finally, the collection of such data as statistics and maps from plantations as well as from government offices. There was of course some modification of procedure as work got underway. For example, emphasis shifted from the formal plenary and sectional meetings to the informal discussions variously arranged among planters' representatives, government officials, and peasant union spokesmen as it became apparent that all substantive negotiation was taking place in the latter. A technical difficulty arose over preparation of a map to show the entire tobacco region between the Wampu and Ular rivers. One made for the state commission proved too small in scale to permit the discriminating delimitation of relatively small parcels of sawah or of kampong grounds and by the time large-scale maps on the scale of $1: 5000$ or $1: 10000$ could be completed most of the information on the fluid squatter situation had become outdated. Another modification was made when to its surprise the state commission, authorized only to make recommendations for subsequent governmental actions, found itself flooded with requests for specific action from the public (about 250 letters in the first two months alone). For the sake of good public relations, a subcommittee consisting of S.M. Tarigan of Section I and Kongsi Sembiring Depari of Section II was appointed to handle this correspondence. 
In terms of special interests, the nine members of Section I, which had been assigned the crucial problem of how to partition the concession lands between estates and local population, fell into three groups. The first consisted of the three government officials: chairman Subakti; vice-chairman Singgih; and Radjamin, head of the Bureau of Land Use Planning in Medan. The second included the three spokesmen for plantation interests: $R$. Nolen, Chairman of AVROS, on behalf of the perennial-crop estates; E.M. Vorstman for the tobacco estates; and Abdul Djafar for the Government Estates Administration, or PPN. The third was made up of representatives of peasant organizations: S.M. Tarigan of the Sekretariat Bersama; Sjamsul Bahri of the STII; and Abdul Kadir of the BPRP. Only the planters' spokesmen managed consistently to present a united front. Of the peasant organization representatives, Sjamsul Bahri of the anything but militant STII defended the agrarian program of the Wilopo Cabinet, the Masyumi Party, and former Governor Hakim, while S.M. Tarigan, leader of the Communist-aligned BTI and chief spokesman for the Sekretariat Bersama, strongly opposed the Masyumi policy, refused to accept any previous agreements, and would have welcomed nothing more than the total defeat of the planters. Knowing the latter was too much to hope for, Tarigan concentrated on wresting from the planters and government officials as many concessions as possible for the squatters. The autochthonous people's representative, Abdul Kadir, found himself between two fronts, the planters on one side and the immigrant groups organized by the militant BTI, Petani, and other peasant factions on the other.

Disunity among the peasant organizations' leaders, which should have benefited the planters, was offset, however, by the open partisanship of vice-chairman Singgih. To the consternation of chairman Subakti, the vice-chairman acted the dual role of an official of the Department of Agrarian Affairs and first vicepresident of Petani in a way so biased and conspicuously on the side of Tarigan and the Sekretariat Bersama as to provoke Subakti to register a protest with Minister Hanafiah in Jakarta. ${ }^{3}$

The political affiliations of the members of the state commission also proved of considerable significance. Five members (chairman Subakti, the three planters' representatives, and Radjamin of the Ministry of Agriculture) professed no political party affiliation. Seven members belonged to parties backing the cabinet (the four representatives of the Sekretariat Bersama, the two representatives of the BPRP who belonged to the PRN, or 
National People's Party, and Singgih, a member of Petani/PNI). Of the three remaining members all belonging to opposition parties, two were from STII/Masyumi. Those backing the cabinet could afford neither the complete failure of the state commission nor a set of recommendations that would constitute a vindication of the previous cabinet's program, and the opposition saw that its interests lay in the confirmation of previous agreements rather than any drastic changes. The planters could, therefore, count on some opposition support in the defense of previously achieved agreements, making their position in Section I stronger than might otherwise have been expected, but theirs was a minority voice in plenary sessions on account of the composition of the membership of Section II.

\section{Position Papers Submitted to the State Commission}

In the course of the four months that the state commission conducted its meetings, important memoranda were submitted by the planters as well as by several peasant unions and by Radjamin, the head of the Bureau of Land Use Planning in Medan. Quite understandably, the position papers reveal a great gap between the views held by the chief protagonists in the agrarian struggle. Whereas the planters used economic and legal arguments and avoided political reasoning, the spokesmen for the peasant unions of ten engaged in political arguments, but they were by no means unanimous and thus did not present a solid front. Instead they were divided into three camps. The spokesmen for the autochthonous rural population were in a minority and found themselves strongly opposed by the other peasant leaders representing the immigrant element. The unions speaking for the non-autochthonous groups were again divided into a moderate group defending Masyumi's agrarian policy and Governor Hakim's program and the militant-radical group led by the spokesmen for the BTI and Petani.

\section{Plantation Industry Statement}

Two weeks after the formal installation of the state commission, the two representatives of the plantation industry presented a statement of the industry's position built around a meticulous summary of the drawn-out negotiations with Indonesian authorities, statistics on the plantation industry's economic contributions to the commonweal, and a shrewdly argued brief for the continuation of its operations in the interest not only of its 
stockholders but also of the Indonesian nation. ${ }^{4}$

Addressing the heart of the agrarian issue, a viable allocation of cultivable land between peasants and plantations, the statement courageously challenged the anti-planter members of the state commission with the declaration that no estate lands were actually needed for peasant agriculture since other parts of North Sumatra possessed an adequate supply of idle soils. The planters nevertheless stood ready to partition their estates according to the 1951 industry-government agreement in exchange for the promised new legislation ensuring a legal status for the plantations. Coupled with the reaffirmation of the agreement was a dire warning of the irreparable economic damage any attempt at separate implementation of the two parts of the agreement would incur.

Points made in the statement were accompanied by careful statistical support. Thus it was noted that since the province of North Sumatra contained 12.5 million hectares and the industry controlled only 0.9 million hectares, counting both agricultural concessions and long leases, the industry held only 7 percent of the land. It was obviously a sly use of statistics to present estate holdings as a percentage of the total area of Tapanuli, Aceh, and East Sumatra. The figure for East Sumatra alone would have shown that the plantations accounted for 26 percent of the area - and made a much less persuasive argument for removal of the squatters.

There were also statistics, given in relation to the mesmeric 7 percent computation, to demonstrate the proportionately high contribution of the plantations to Indonesia's economy. Of the total North Sumatran population of 4.5 million, 12 percent or 550,000 (laborers and their families) owed their livelihood directly to the plantations, and even more did indirectly through such related business activity as trade, transportation to and from portside, and stevedoring. Estate agriculture, clearly, supported at least one-fourth of the North Sumatran population. To this must be added the benefit to the whole country of the plantation industry's foreign exchange earnings, which in 1952 amounted to approximately Rp. 1.94 billion or 18.6 percent of Indonesia's total Rp. 10.4 billion. Moreover, the industry paid in wages per year about Rp. 600 million excluding the costs of social services.

In view of all these facts, the statement concluded, it was to everyone's advantage that the estates of North Sumatra, occupying so small a proportion of the total land area, be left intact as far as practicable. A true settlement of the agrarian issue meant 
finding an integral solution to the problem of security for both peasant and plantation agriculture. Though concerned for the trampling of some individuals' rights, which even the most carefully conducted separation of estate and peasant land would entail, the directors of the plantation companies felt the state commission should look for a balance between the needs of the two sectors with allowance for the fact that the companies had already agreed (in the case of tobacco estates) or were prepared to agree (in the case of perennial-crop estates) to give up a large portion of their lands. Rational operations required, however, that every effort be made to move squatters located deep inside the remaining areas of the estates, at least to the fringe if not outside.

The planters' statement contained a summary of the 1951 government-industry agreement based on the report of I.J. Kasimo and Jusuf Muda Dalam to Parliament in which it was asserted that the planters could relinquish about 300,000 hectares without jeopardizing their operations. Reference was then made to the draft "Act for the Reorganization of Land Use in East Sumatra" originally prepared by Iskaq Tjokrohadisurjo, Minister of Interior in the Sukiman Cabinet, but revised four times up to 1954 because of either cabinet changes or parliamentary objections. This draft act called for (1) a reduction of the tobacco area from 255,000 to 125,000 hectares; (2) a reduction of the other crop areas by one-third, or about 180,000 hectares; (3) the granting of new agrarian rights for estates; and (4) protection of the planter by the penal code against violations of his new agrarian rights. As the statement noted, opposition to the draft law plus chaotic conditions in East Sumatra had led Minister Iskaq to issue his well-known decree of 28 June 1951, which was followed by the North Sumatran governor's decree of 28 September 1951. Meanwhile Governor Hakim, dissatisfied with the original land division proposed by the planters had insisted on a revision based on the principle that the planters let go: land along the major highways to a depth of 250 meters on each side; land already converted into sawah; and land already used or needed for an expansion of villages and towns. Commissions consisting of representatives of the civil service (pamong praja), the planters, and the Office for the Execution of Land Distribution (KPPT) thereupon examined each plantation, taking cognizance not only of the governor's ruling but also of the existing squatter settlements and the future needs and interests of both local peoples and estates. The planters claimed that during these nego- 
tiations, on request of the pamong praja, 13,000 hectares of land in excess of the amount shown on the approved land division map had been relinquished where such land was especially well suited for future conversion into sawah, so that the tobacco industry no longer had 125,000 hectares but only 112,000 hectares for its operations. In return for this additional release the planters asked only for speedy resettlement of those squatters occupying any of the remaining 112,000 hectares.

As to perennial-crop estates, the representatives recalled that in July 1952 AVROS had informed the government of its readiness to give up 180,000 hectares provided it would receive guarantees permitting a rational operation of the estates. The governor in a letter of 23 May 1953 had accepted this "land offer" of AVROS and since then preparations for the division had been going forward.

Turning to the question of soil quality, the statement pointed out that some areas especially suited to tobacco cultivation had already been sacrificed in the interest of speeding a final agreement and that further reduction of the tobacco area would seriously impair future operations. The planters took the stand that, except for minor adjustments for practical reasons, the tobacco land boundaries had been settled and the matter should be considered closed. The statement ended with a promise of loyal cooperation with the state commission in the search for a final solution of the long-standing agrarian issue.

On 17 June 1954 the representative of AVROS submitted a second memorandum to the state commission. ${ }^{5}$ It was pointed out that, besides such economic consequences of squatter-caused estate closings as a decline in production, a weakened market position, and the reduction of employment opportunities for the people, there were the less obvious but nevertheless damaging effects of illegal squatting on soils and drainage systems. Land occupied during the war and postwar periods had often been abandoned by the squatters because the soil had become completely exhausted. Only heavy applications of fertilizer and the repeated plowing under of green manure crops could restore these soils to use for the raising of tobacco. Estates forced to plant insufficiently regenerated soils found both yield and quality of their tobacco disappointing. Furthermore, the continual cultivation of maize had caused heavy erosion, with resultant damage to the drainage ditches, so essential for the cultivation of tobacco and constructed at great expense by the companies. In other instances the construction of improperly 
designed irrigation had caused serious damage to standing crops and interfered with estate operations. Still another impediment to efficient estate management was the scattered location of squatter holdings, which broke up the large crop areas needed for optimum use of men and equipment. This was particularly true in the sisal industry, where production had declined from an annual prewar total of 60,000 tons to about 18,000 tons and left factory capacity only partially utilized.

The memorandum went on to analyze the differing types of squatters - estate laborers, native villagers, and recent immigrants. The estate laborers had originally acquired temporary rights to garden plots during the wartime food shortage and afterward refused to return, and even expanded, these holdings. To classify estate laborers as farmers was to confuse their primary occupation as laborers with their private cultivation of illegally held estate land. For practical reasons it was undesirable that laborers engage in private farming for this meant divided energy and therefore lowered efficiency on the estate.

Not until the evil of illegal occupation of estate land by laborers and immigrants had assumed great dimensions did the local villagers begin to fear a land shortage and to grab estate lands adjacent to their kampongs. The local villagers were also guilty of abandoning their own exhausted soil for estate lands, repeating there the process of soil exploitation.

As to the third group of squatters, the memorandum directed attention to the ever growing hordes of migrants streaming from the Karo highlands and Tapanuli to East Sumatra. Their "nomadic wasteful land exploitation" exhausted dry land in a short time and "seriously disturbed the agro-social structure of East Sumatra". The implication stood out clearly that, whereas Javanese estate laborers and local villagers were integral parts of the social order of East Sumatra, the Batak immigrants were intruders.

\section{Statement of the Joint Secretariat of Peasant Organizations}

To supply their own perspective to their position, the peasant organizations opened their statement with a lengthy review of the agrarian issue from before the war through the immediate postwar period. ${ }^{6}$ The common people of East Sumatra, it observed, had had to struggle with agrarian difficulties ever since the opening of the estates. They had lost a great deal of their land and had been pushed to the banks of the rivers, to the coast and up into the foothills. This had led to a decline in the 
productivity of smallholder agriculture. The difficulties which confronted East Sumatra were a heritage of the colonial period. Now that Indonesia had become a free country, the planters, as guests of that country, must bring their point of view into line with the changing times.

There followed some specific proposals. First, the tobacco industry should release additional land both because shortening of the rotation period from eight to five years, as scientific research had shown was possible, would decrease the area needed and because the 130,000 hectares of land released under the 1951 agreement were unsuitable: 45,000 hectares lay in swampy or deeply dissected areas, another 45,000 would require extensive and costly preparation for smallholder use, 20,000 belonged to decades-old kampongs, and the remaining 20,000 were by and large already occupied by farmers. Nor was the perennial-crop estates' offer of 180,000 hectares acceptable. The Sekretariat Bersama considered the area actually cultivated by these estates before World War II more than enough for their continued operation and all other holdings should be released.

Several proposals in the concluding section went considerably beyond previous arrangements, notably, that every farmer receive either 2 hectares of dry land or 1 hectare of irrigated plus half a hectare of dry land and that the classification "Buruh Tani Ladang" be dropped; that there be no relocations outside the kecamatan; that the estates transfer to the jurisdiction of the Public Works Department the land on both sides of public roads to a total depth of 1,000 meters, including the road itself and, outside the tobacco region, old, no longer productive stands of perennial crops; and that the people be granted permission to construct irrigation canals across planted estate lands.

These and the remaining proposals on the type and magnitude of the government's financial and other support to farmers who had to accept resettlement were possibly negotiable, but the planters immediately challenged the contention that the tobacco rotation could be safely reduced and demanded scientific proof. Their own research station, staffed with highly qualified scientists, had spent large sums of money on the problem and so far had found no evidence that the rotation could be reduced without significant losses in yield and quality.

The planters conceded that the rotation could be shortened from eight to seven years if the jaluran system were abolished, but Tarigan, the peasant organizations' spokesman, rejected such a step. Though neither Tarigan nor any other member of Section 
I could disprove the defense argument of the tobacco planters, a political solution was reached in a compromise formula, a proviso calling for automatic additional reduction of the area reserved for the tobacco industry should future research prove the safety of a shortening of the tobacco rotation despite the continuation of the jaluran system. Section I debated with similar tenacity the pending reduction of the area held by perennial-crop estates. Unsatisfied with their offer to release 180,000 hectares, Tarigan demanded that an upper limit of 345,000 hectares of planted area plus the necessary "tara" lands needed for roads, settlements, and the like be set for the perennial-crop estates. This the planters rejected, maintaining firmly that the decision as to what was needed for rational economic operations belonged to the estates. It was not a matter for bargaining and was unaffected by Tarigan's argument that one-third of the estate area amounted to 220,000 hectares rather than 180,000 . Once more an impasse, followed by informal discussions leading to the following compromise formulation:

"The state commission starts with the assumption that one-third of the estate area is to be returned, but it accepts the planters' voluntary offer of 180,000 hectares. However, should this offer of 180,000 hectares not provide a solution, then ... the area to be returned shall be increased to one-third of the present estate area with the proviso that the entrepreneurs receive public domain land of the same size as compensation."7

\section{Statement of the Autochthonous People}

The Council for the Struggle of the Autochthonous People (BPRP), represented by Abdul Kadir and Kongsi Sembiring Depari, spiritedly defended the special interests and claims of the autochthonous people, whose ancestors had been virtually the only population element in East Sumatra at the time of the arrival of the planters. The descendants argued, understandably, that their agrarian rights, based on adat law, should take precedence over the "purely politically inspired" claims of immigrants and their descendants (whether from other parts of Sumatra, from Java or Borneo, or from China or India) who had come to East Sumatra in search of employment offered by the planters. The Council then proceeded to issue a so-called Public Declaration (Keterangan Umum) which flatly stated their opposition to a policy of demanding the return of estate lands to the populace so long as Indonesia stood in need of foreign 
capital, pointing out that a drastic reduction in estate-operated lands would cause heavy losses for plantation companies and, in turn, for the state treasury. ${ }^{8}$ There was, for example, the testimony of agricultural experts that the tobacco soils of East Sumatra were the best in the world, capable of producing far greater per-hectare returns of foreign exchange than land in any other part of Indonesia. The Council expressed the further fear that the compulsory return of plantation land would actually aggravate the land shortage for the local peasantry because of the resultant influx into the tobacco region of villagers coming from outside the region (i.e. from Tapanuli).

The current agrarian debate, the statement argued, was simply a continuation of the conversion debate, interrupted by World War II and the Japanese invasion, which sought a change of the agrarian base from that of an agricultural concession to a long lease for the land remaining in the possession of the plantation entrepreneurs. The latter justifiably felt conversion offered the only practical safeguard against an accelerating shrinkage of their holdings due to their obligations to the local population. These obligations, accepted by the planters under the old contracts, called for the release every five years of enough additional parcels of land, i.e. 4 bouw or 4 hectares, to meet the increase in the number of households with legitimate agrarian claims. Admittedly the prewar conversion negotiations had bogged down because the planters offered the former rulers only land in remote locations or of poor quality, but to settle now for an over-all handling of the agrarian issue might result in violation of the autochthonous population's customary rights. The Council therefore insisted on the fulfillment of the legal obligations of the planters to the local population prior to a partition of the land between planter and government and prior to the issuance of any new agrarian rights by the government to the planters.

As to the objection by the radical peasant and labor leaders that this amounted to preferential treatment, the statement noted that the various regions of Indonesia all had their customary agrarian laws and that East Sumatra did not differ in this respect from Tapanuli or the Minangkabau region. Furthermore, there was no better proof of the existence of a long-standing and time-honored adat concerning land than the provisions of the model contracts of the $1870 \mathrm{~s}, 1880 \mathrm{~s}$, and 1890s. It would indeed have been unnecessary to include restrictions in these contracts for the protection of the rights of the autochthonous population had there not existed a set of customary laws pertaining to land. 
With the deposition of the sultans, the government had become arbiter of the legitimate rights of the planters as well as of the local population and so had the obligation to see that, whatever action was taken in view of the changing times and the new social order, "the local people who have agrarian rights testified to by the model contracts were not harmed".

In addition to the Public Declaration, the Council for the Struggle of the Autochthonous People on 24 June submitted a set of specific demands divided into two groups, one applicable to the tobacco estates and the other to the perennial-crop estates, as summarized here:

\section{Claims Applying to Tobacco Estates}

1. kampong areas must be at least three times the size of the land actually occupied by the kampong proper;

2. each family must be given its four bouw of land;

3. jaluran rights must be in force in the future;

4. kampongs of the autochthonous people may not be transferred to new sites; wherever possible the land to be given to the villagers will be adjacent to the kampongs and will form belts connecting adjacent kampongs with each other;

5. the land to be assigned to the autochthonous population must be located on a road;

6. no differentiation must be made between autochthonous people living within or outside the plantation to whose land they have claims;

7. the autochthonous population is to receive material and financial aid in order to be able to practice modern agriculture; a special cooperative is to be established for the autoch thonous population;

8. the autoch thonous population refuses to accept cancellation of its customary agrarian rights unless the same principle applies to all parts of Indonesia;

9. should autochthonous elements of the population have to be relocated they must receive the same treatment as all other peoples subject to resettlement;

10. in districts which lack jaluran parcels and in which the four bouw have not yet been allocated, the autochthonous people must be given potential swidden land (tanah rabian) for the production of rice and other crops.

II. Claims Applying to Perennial-Crop Estates

Before returning land to the government, entrepreneurs must first satisfy the claims of the autochthonous population; in par- 
ticular, they must provide adequate amounts of land for kampongs together with 4 bouw per claimant family. The autoch thonous people also demanded:

1. that their kampongs not be transferred to new sites;

2. that the location of the kampongs be taken into consideration in the choice of the land to be returned;

3. that the 4 bouw claimed per family must be adjacent and contiguous to the kampong so that the latter is not separated from the crop land;

4. that this land be well-suited for smallholder agriculture and be located on an all-weather road;

5. that the planters pay compensation for fruit trees belonging to the villages but located on estate land.

The views and demands of the autochthonous population were strongly opposed by the militant labor and squatter elements in the state commission, who accused the spokesmen of being "feudal" in their outlook and of betraying the spirit of the revolutionary struggle. After lengthy debate on their demands, the plenary session of 7 May passed the following resolution:

"The autoch thonous population will receive the same treatment as the rest of the population in accordance with Article 6 of the Ministerial Guidelines, which reads as follows: 'In the selection of land to be set aside for plantation agriculture one must always reckon with land reserves capable of:

a. absorbing the population growth of about 50 years, i.e., the maximum duration of agrarian rights grantable to a plantation;

b. satisfying the agrarian rights of the autochthonous and other Indonesian people with equal claims.' The discussion regarding the agrarian problem of the autochthonous population will not be continued since this issue will be turned over to the central government." 9

\section{Statement of the Bureau of Land Planning}

The state commission benefited greatly from the memorandum prepared by Radjamin, the head of the Bureau of Land Planning and a member of the commission. ${ }^{10}$ In a rather detached academic manner Radjamin examined the historical background of the agrarian problem, which he called "a burning issue" on account of its implications for security, state finances, and public welfare. The present situation, he reminded his colleagues, could be understood only if one knew the past. Here is an abridgment of his remarks: 
At the time of the arrival of the first planters East Sumatra was mostly virgin forest land with a very small population, so that concessions could be granted everywhere once it had been recognized that the soils were very fertile. Quickly East Sumatra developed into a plantation region of great repute both within and beyond the boundaries of Indonesia. Applications for agricultural concessions and hereditary leases came in so fast that within a few decades East Sumatra was turned into one great continuous plantation belt. Its plantations bordered on each other so that the agricultural land of the local peasantry was squeezed between estates or was located within estates.

By the beginning of the twentieth century the land not belonging to plantations consisted of coastal swamps - which could not be brought under cultivation by the peasant population although the soils were known to be fertile - and mountain slopes. The population increased due to the importation of hundreds of thousands of laborers; a network of good roads and railroads criss-crossed the plantation region; harbors were developed; offices and hospitals were constructed; and in a few places towns and cities arose. All of this brought East Sumatra in as sharp a contrast with other neighboring regions as that between night and day. It is, therefore, not at all surprising that the population of the neighboring regions began to migrate to East Sumatra in search of employment on the estates.

The local population was incapable of producing adequate quantities of rice, so that it became necessary to import rice from abroad, especially from Burma, Thailand, and Indochina, and in small quantities from Aceh and Tapanuli.

During World War II the estates did not operate; and many people lost their source of income. The links with foreign countries were interrupted; communications with Aceh and Tapanuli became difficult. All of this meant a critical food shortage which could be met only by an increase in local food production for which estate lands were used. Not a single authority attempted to stop this, and many who had never engaged in food production now raised their own foodstuff in order to survive.

After the transfer of sovereignty the migration to East Sumatra increased greatly and led to large-scale squatting on estate lands, since the bulk of the immigrants had no special skills and thus could only engage in farming.

The situation can be summed up: 
1. the plantation region represents the best developed part of East Sumatra;

2. the majority of the population of East Sumatra lives within the plantation region;

3. employment opportunities and social services are better in the plantation region than in surrounding areas;

4. the plantation region therefore greatly attracts people from the outside, most of whom are only able to make their living as small peasants;

5. the prosperity within the plantation region is to be attributed to the estates; the plantation region represents an important source of income for the government;

6. the plantations have the best geographic location and are the largest agricultural enterprises, but not all of their land is actually under cultivation - they are holding large reserve areas;

7. the holdings of the peasants are very small and are located between the plantations and have no possibilities for expansion; the reserve lands of the smallholders are far distant from the villages and cannot be developed by these producers without aid;

8. although the plantation region is prosperous in many respects, it suffers from a food shortage and depends upon foreign sources as well as South Aceh and North Tapanuli;

9. since plantations cannot operate in peace and their laborers too become squatters in order to gain their livelihood, the squatter problem grows in magnitude and harms the state severely;

10. on the whole the people prefer to be smallholder peasants and part-time wage laborers rather than full-time laborers.

All these points must be taken into consideration in the search for a solution of the agrarian problem of East Sumatra. Obviously the interests of the peasantry cannot be ignored and pushed aside; instead the peasants must be given adequate amounts of agricultural land. This is possible if the plantations are reduced in size without endangering their economic future and the unutilized lands of the public domain are developed. In the neighborhood of the plantation belt are extensive cultivable areas of public land provided the land can be drained. Some 20,000 hectares of swamp land can be converted into irrigated rice fields. Provided that these lands are opened up by good roads they will be in great demand since the soils are as fertile as those of the plantations. Once the new lands are properly opened up and 
easily accessible the land-hungry peasants will not object to resettlement. All of this requires large expenditures which, however, would seem well justified.

This procedure can be applied to the squatters already on plantation land, but this probably will not solve the problem, since the land thus freed of squatters will promptly be occupied illegally by new immigrants. This highly irregular migration must be brought to a halt - not by means of a law or a set of regulations but through the development of new agricultural lands in the districts from which the migrants come.

Only large-scale opening of potential agricultural land in and on the fringe of the plantation region could lead to a satisfactory solution of the agrarian problem regarding the future of the plantation lands.

There are then two aspects of a successful program:

1. Open up new agricultural projects (both irrigated and unirrigated land) on land either returned by planters or, coming from the public domain, provide them with roads, and reserve them for peasants who are squatting on plantation lands which are to remain under the control of the planters.

2. Simultaneously open up agricultural projects, involving both irrigated and unirrigated land, in the areas surrounding the plantation region so as to prevent a new influx of migrants.

Only the simultaneous execution of these two measures will solve the squatter problem, create economic peace and order in the highly disturbed plantation region, and at the same time balance the well-developed sections of East Sumatra with the presently less developed districts within and on the borders of the residency.

This memorandum and recommendations of Radjamin's, which of course delighted the planters, received full discussion in the plenary session of 26 July and his specific two-point program was adopted with the proviso, insisted on by the representatives of laborers and squatters, that the development projects start on lands to be returned by the planters.

\section{Statement of the Sarikat Tani Islam Indonesia (STII)}

The Masyumi peasant organization, STII, predictably followed the policy laid down by the Wilopo Cabinet and implemented by Governor Hakim. Its position paper accepted all previous agreements and arrangements and made no new demands, thus placing the STII in opposition not only to most other peasant organiza- 
tions of East Sumatra but also of course to the agrarian policy of the Ali Sastroamidjojo Cabinet. ${ }^{11}$

\section{Van der Molen's Report on the Squatter Situation in the} Tobacco Area

In response to a request in April from Abdul Djafar, K. van der Molen, head of the agrarian section in the United Deli Company, submitted a memorandum dated 3 May 1954 on the extent of squatting in the tobacco region, particularly changes in the situation between mid-1953 and 20 April 1954. Such a report, Van der Molen began, was made extremely difficult by the fluidity of the squatter situation, which changed so rapidly as to outdate statistical data even as these were being collected. ${ }^{12}$ Furthermore, though plantation personnel could count dwellings, the number of squatters remained unascertainable since several families might share a dwelling and the uncooperative or even openly hostile attitude of most squatters toward being counted made actual entry to check nearly always inadvisable. Even where circumstances did allow a determination of the true number of squatters, the count was still likely to be unreliable because squatters quite often occupied several parcels of land under different names.

Van der Molen reasoned, moreover, that the actual number of squatters reflected neither the magnitude of the agrarian problem nor the bona fide land requirements of the squatters. Many squatters did not support themselves and their families exclusively as cultivators but were working either full time or part time in such capacities as estate laborers, dock workers in Belawan harbor, clerks for private companies, employees of government agencies, and small traders. Such squatters gravitated to estates near major urban centers, the good roads there permitting daily commutation to their place of employment. One might regard them as "part-time squatters". Registration of squatters without careful probing into their background and economic activities therefore could not possibly provide an accurate picture of their land needs. (While the Sekretariat Bersama wanted equal treatment for all squatters, the planters defended the early practice of classification of squatters into true farmers and those who depended upon farming only as a supplementary source of income.)

Van der Molen pointed out that large portions of the tobacco lands released in 1951, including areas suited for the development of sawah projects, remained unused or only partly used, 
while estate lands continued to be held by squatters. Land that had been lying fallow for many years and was therefore covered by second-growth forest held far less appeal than land on estates still in operation, with their well-maintained roads and bridges. Above all, the estates themselves offered opportunities for occasional employment - such as the setting up of market stalls for the sale of snacks, coffee, soft drinks, and cigarettes. The estate labor force, furthermore, provided a market for farm products. In short, the squatters preferred to live on a plantation in full operation rather than on one which had been closed for years, and this explained why for the United Deli Company alone the squatter area had increased about 10 percent between 28 August 1953 and 1 May 1954.

\section{Report of the State Commission}

Several times as the weeks passed the fate of the state commission hung by a thread, but because no one wanted to bear responsibility for failure of the discussions, deadlock was assiduously avoided. The resultant prolongation of the sessions ruled out completion of the agenda by 10 May 1954, necessitating an extension of the state commission's authority for three months - one month being the fasting month (puasa) during which by common consent there would be no meetings. Thus the state commission did not complete its work until 10 August, almost a year after its establishment, but there had been an impressive total of twelve plenary sessions, twenty-six Section I sessions, and fourteen Section II sessions, plus the many informal meetings. Vice-Chairman Singgih left for Jakarta soon thereafter to draft the final report while the other members, with varying degrees of apprehension, sat back to await the result. ${ }^{13}$

Copies of the draft report reached members on Saturday 2 October together with a memorandum calling for a plenary session the following Monday to give Singgih formal approval of the draft before his return to Jakarta on Tuesday 5 October. This attempt to rush the report through brought vigorous protests from all quarters and forced Singgih to accept a compromise whereby members were given a week to draft and forward to Singgih in Jakarta their comments, a delay subsequently stretched to cover two additional plenary sessions on 20 October and 12 November.

Singgih's first chapter, a long historical essay, drew protests from the planters' representatives on grounds of both pertinence 
and accuracy. Arguing that agrarian history had not been an important subject of the discussions and had not been called for by the cabinet, the planters' representatives suggested the chapter be made a part of the appended material and clearly attributed to its author, so that the commission did not have to share in the responsibility. Agreeing to a few revisions, Singgih was nevertheless unwilling to transfer the essay to the appendix, his only concession being the addition of a preface in which inclusion of this material in the body of the report was defended and the admission made that the decision had not been unanimously approved by the members.

The second, third, and fourth chapters drew few objections, being more or less routine reviews of, respectively, the agrarian situation as of 27 August 1953, the formal establishment of the commission, and its procedure and accomplishments (the latter with special reference to concurrent standfast changes, see below).

There was considerable debate, however, over the last two chapters, "Results of the Commission" and "Short Summary of the Recommendations and Suggestions of the State Commission for the Partition of the Estate Lands of East Sumatra". First of all, the planters were startled to find in the draft report some recommendations by Section II which, though clearly bearing on estate interests, had never been brought before Section I. Two of these stirred particularly strong protests, viz. one that squatter resettlement be limited to only 2,000 families the first year and the other that the estates assume half the resettlement costs. Abdul Djafar pointed out that, taking the common estimate of 86,000 squatter families, the proposed annual limit on resettlements would put off for decades any final solution of the supposedly urgent land problem and could therefore only be interpreted as an irresponsible delay tactic. As for the estates paying half of all costs, estimated at about 8 million rupiah per one thousand families, Abdul Djafar expressed shock that so momentous a recommendation for the planters had not been discussed or even mentioned in any Section I or plenary session. Nolen and Vorstman voiced similar objections to the two recommendations in their strongly worded formal protest, which was submitted to Singgih with the request that it be included in the final report. The planters' statement was buried in the appendix.

Little else in the draft report could be considered a surprise. Below is a summary of the recommendations made by each of the two sections: 
Section I. Since the principal task of this section was the land division, for which there already existed a basis for agreement, its recommendations were fewer in number than those of Section II. Succeeding only in part in their tenacious defense of previously reached agreements, the planters finally acceded to a formulation that additional land would be released by the plantations if subsequent practical implementation of the partition and resettlement program proved that squatters qualifying for land could not be taken care of within the limits of the land area originally released by the planters. Such an eventuality was made acceptable to the planters by the promise of compensation in the form of new lands to be taken from the public domain.

The remaining recommendations related to such matters as a new registration of the squatter population with classification into genuine farmers and non-farmers; formation of strong farming communities; concentration of the squatter population wherever possible in compact villages; and proper coordination of population transfers with adequate land preparation and other support programs to be suggested by Section II.

Section II. Except for the very troublesome issue of the special demand of the autochthonous population (disposed of, as noted earlier, by formally referring responsibility to the Jakarta government), there was little disagreement among the representatives of the peasant organizations who made up this section. Their only concern was the coordination of their demands for more land and generous government support of squatters subject to resettlement. The most important of the Section II recommendations were: limitation of first-year resettlement to 2,000 families; a careful selection of land for resettlement projects; adequate compensation for the loss of immovables; payment of all costs resulting from the resettlement; granting of a moving subsidy of Rp. 1,500 per family; clearing and other preparation of the land prior to the arrival of displaced families; speedy issuance of agrarian rights to land assigned to former squatters; construction of roads and bridges to make the new settlement sites accessible; provision of agricultural implements, seed fertilizer, and credit; provision of such social services as schools; and construction of mosques and village community centers. Section II also recommended the development of irrigation projects on former estate lands as well as on public domain lands both within and outside East Sumatra in the neighboring parts of the province of North Sumatra so as to forestall further migration to East Sumatra.

In concluding the report, Singgih claimed that the state com- 
mission in the five months of its work had calmed the growing unrest among the squatters of East Sumatra, provided a welcome opportunity for joint consultations between planters and peasants, and fostered mutual contacts and a better understanding among peasant organizations. Not everyone agreed as approval of the draft was forwarded reluctantly to Jakarta and the report finally presented to the cabinet in December $1954 .^{14}$ The planters, for example, felt that the generous support program would only lead to additional invasions by new squatters acting in the hope that they too would be granted the same benefits. This pessimism was based above all on developments since 27 August 1953 and on the vacillating handling of standfast orders in East Sumatra.

\section{Standfasts and Their Enforcement}

Theoretically, all instances of unauthorized occupation of estate lands should have led to legal prosecution according to Ordinance No. 110 of 1948, an ordinance which had been reaffirmed in the Joint Statement of the Wali Negara of East Sumatra and the Military Commander on 22 May 1950 and which the government had not yet been able to replace with a parliamentary law to the same effect. By 1953, however, civil authorities, police officials, public prosecutors, and judges had become most reluctant to enforce a "colonial law".

The agrarian issue took a different political direction, however, with the creation of the state commission and on 27 August 1953 the central government declared a standfast, applicable to both planters and peasants, to stabilize the situation until its recommendations were in. It soon became apparent that the militant wing of the peasant organizations intended to ignore the new standfast. As the organized invasions of estate lands followed one after another in late 1953 and early 1954, AVROS sent repeated letters of protest with lists of standfast violations to the district and provincial authorities, including the governor, as well as to the Ministry of Agrarian Affairs. ${ }^{15}$ The squatters obviously no longer feared prosecution and in fact regularly committed illegal acts under the very eyes of the police and the civil service officials. The planters were not only losing their land but their confidence in the government's ability to solve the land problem fairly. As Nolen kept stressing in his letters to government officials, the unprohibited and unpunished violation of the rights of third parties was causing general demoralization, was 
daily compounding the difficulty of finding a quick solution to the land problem, and, certainly not to be overlooked, was endangering an important sector of the economy.

On 1 March 1954 Nolen appealed to the Attorney General for help, explaining that the provincial authorities had claimed to be unable to act. ${ }^{16}$ Possibly in response to this and other letters of this nature, or because of instructions from Jakarta, the governor issued a proclamation on 19 March $1954^{17}$ which reconfirmed the standfast of 27 August 1953 and ordered squatters who had violated this standfast to vacate the estate lands by 26 March 1954 or face arrest and legal prosecution, while squatters whose illegal entry of estate grounds predated 27 August 1953 received permission to remain awaiting the outcome of the deliberations of the state commission just installed on 10 March 1954. As could have been predicted, the proclamation reconfirming the standfast of 27 August 1953 brought a storm of protests from BTI and from Petani as well as from the Sekretariat Bersama. Under the impact of these protests the governor weakened and issued another proclamation on 6 April $1954^{18}$ that gave the standfast violators until 20 April 1954 to vacate estate land. Apparently nothing happened during the following two weeks, but on 20 April a delegation of the Sekretariat Bersama presented the governor with new demands, to which the governor again acceded by extending the evacuation date by one month for all those squatters who had violated the standfast before 31 December 1953 to allow the harvest of their crops. The governor also agreed to order the release of all those who had been arrested because of violation of the standfast but not yet tried in court and to provide government aid in the form of land, use of tractors, and transport as well as financial support up to Rp. 150,000. To cap its triumph, the Sekretariat Bersama was then given the right to name half the members of a special committee set up under the chairmanship of Bupati Tengku Hanafiah to supervise the resettlements. Governor Amin's capitulation to the militant wing of the peasant movement provoked highly critical editorials in such Medan newspapers as Lembaga, Mimbar Umum, Mestika, and Tangkas.

Before Tengku Hanafiah's committee had had a chance to make much progress with its assignment, the cabinet issued Emergency Law No. 8/1954, effective 12 June 1954, in an effort to stabilize the situation and put the search for a "solution of the problem of use of estate lands by the people" on a national rather than local level. The new law, signed by the Ministers of 
Agrarian Affairs, Agriculture, Economic Affairs, Internal Affairs, and Justice, authorized the Minister of Agrarian Affairs to appoint negotiators - governors, other officials, or commissions as dictated by circumstances - to arrange agreements between estate owners and squatters in all land conflicts existing as of 12 June 1954. The planters noted a welcome firmness in the stipulations that unauthorized use of estate land occurring after 12 June 1954 would not qualify for negotiation and any new squatter would be subject to a prison term of up to three months or a maximum fine of Rp. 500. It was also reassuring to read that agreements reached by negotiation would be legalized by a joint decree of the five ministers with the same penalties set for the violation of any provision of such a decree. Furthermore, both new squatters and violators of a decree were to have 14 days from the time of sentencing to vacate land before being evicted "by the strong arm". But the law also provided that, in cases where a party refused to enter negotiations or where negotiations ended in deadlock, the official or the commission concerned was to propose an independent solution to the five ministers for legalization by decree, an imposed solution being treated the same as a negotiated agreement.

One question left unanswered by the new law was how violators of the East Sumatra standfast of 27 August 1953 should be handled. Should the committee of Tengku Hanafiah resettle them? On 5 July 1954 the representative of AVROS requested the Minister of Agrarian Affairs to uphold for East Sumatra the standfast of 27 August 1953, because the directors of AVROS feared that otherwise the prosecutors and judges of East Sumatra would refuse to handle squatter cases dating prior to 12 June 1954. Minister Hanafiah, according to Nolen, agreed that violators of the 27 August 1953 standfast must be ejected and rejected Singgih's suggestion that the standfast for East Sumatra be changed to 12 June 1954. But Singgih is supposed to have persuaded Governor Amin to issue a proclamation on 12 July $1954^{19}$ that set as the new standfast date 12 June 1954. Point 4 of the proclamation stated that resettlement actually in process, or resettlement of squatters who had agreed to move but had not yet begun, could be completed, provided the squatters concerned did not object.

The proclamation of the governor came unexpectedly and meant a further setback for the planters and victory for the followers of BTI and Petani. Nolen protested in Medan as well as in Jakarta. The Minister of Agrarian Affairs was unwilling to 
suggest a cancelling of the governor's proclamation, particularly in view of the above mentioned point 4 . Nolen's letter of protest to the governor outlined the reasons why an enforcement of the standfast of 27 August 1953 was so important in the opinion of the planters: ${ }^{20}$

"According to my firm conviction all areas illegally occupied between 27 August 1953 and 12 June 1954 should be vacated in the interest of a satisfactory solution of the agrarian problem for the following reasons:

1. The squatters involved are punishable, since they acted deliberately and knowingly against expressed prohibitive enactments of the government which constitutes a serious violation of government authority;

2. The authority of the central government and especially of the provincial government would be seriously harmed if those persons who did not obey the specific orders to vacate the squatted lands would be treated in the same way as law-obeying citizens;

3. The granting of protection to those who deliberately violate governmental orders will have a demoralizing influence on government officials as well as on the population, so that respect for Emergency Law No. 8 also cannot be expected;

4. The confidence of the planters in a fair solution of the agrarian problem of East Sumatra will be seriously harmed inasmuch as they can point to explicit promises of the government and to loss of all legal security because of a break of the promises;

5. The work of the 'State Commission for the Division of the Estate Lands of East Sumatra' is based entirely on the situation as it existed on 27 August 1953 and should lose all meaning should the date be altered."

Nolen referred also to his discussions of 5 July 1954 with Minister Hanafiah and repeated his argument that Emergency Law No. 8 did for all of Indonesia what the cabinet's standfast order of 27 August 1953 did for East Sumatra alone: call a halt to continued illegal occupation pending the outcome of the work of the state commission. Nolen further pointed out that, according to a high official of the Ministry of Agrarian Affairs, Ordinance No. 110 of 1948 had not been revoked.

This letter was answered in the name of the governor by Bupati Abdul Wahid Er, who outlined the reasons why the governor had to reject the arguments against the change of the standfast date. ${ }^{21}$ 
The bupati remarked that indeed Ordinance No. 110/1948 had not been revoked, but that it was now applicable only to land of the public domain, while estate lands were covered by Emergency Law No. 8 of 1954 - an interpretation which gave additional food for pessimistic thought to the planters.

By the end of 1954 the future looked rather dark for all sectors of the plantation industry of East Sumatra. The planters no longer had confidence in Governor Amin and were apprehensive about further activities of Singgih, who in their opinion was constantly playing into the hands of the Communist-linked BTI and their allies, the Petani. Above all the planters noticed with great concern that the provincial authorities failed to enforce even the standfast of 12 June 1954, while that of 27 August 1953 was completely forgotten. This fact was not altered by another governor's proclamation of 2 December $1954^{22}$, which specifically warned squatters against the construction of permanent or semipermanent buildings, the planting of trees, and the conversion of dry land into sawah and warned the planters against the cultivation of land which was still under dispute. The governor declared that such illegal acts would not be taken into consideration in the final settlement of the dispute and would thus fail to strengthen the claims of the parties concerned. 

(1955-1956)

The hopes for speedy action by the Ali Sastroamidjojo Cabinet on the recommendation of the state commission were not realized - in part due to a change in the cabinet. On 19 November 1954, shortly before the report of the commission was submitted to the cabinet, Minister for Agrarian Affairs Mohammad Hanafiah had been replaced by Gusti Gde Rake. Now a new minister had to familiarize himself with the thorny East Sumatra problem.

In early February, Minister Gusti Gde Rake visited East Sumatra for a firsthand look at the squatter situation only to stir a controversy by forthrightly defending the agrarian claims of the indigenous population and then, in effect, expressing his disapproval of the state commission's rejection of demands by the rakyat penunggu for special consideration on the basis of their customary law. It was an open invitation to political attack for, with the notable exception of the National People's Party (PRN), there was near unanimity among political parties on the principle of equal treatment for all Indonesian citizens. Most vocal of course in assailing the new Minister's position were the immigrant groups, especially the Javanese, the Toba Batak, and other ethnic groups which had moved to the East Coast of Sumatra, but editorials and letters to the editor in the Medan press sometimes reached a shrill partisan pitch too as the pros and cons of the issue were aired. The following summaries offer highlights of the debate:

Lembaga (4 February 1955), a Masyumi-oriented paper which had supported Governor Hakim in 1952 and 1953, used Gusti Gde Rake's statements as a welcome opportunity for a long editorial in defense of the special agrarian rights of the autochthonous population. Certain groups known to be jealous guardians of their own adat-based agrarian rights in their home territory did not care to take into consideration the status of the land in someone else's territory, the Lembaga editorial charged, 
adding that "dark political agitation" was hampering all attempts to find a fair settlement of the issues. It further complained that autochthonous people presenting their legitimate claims were unfairly labeled provincialists and separatists.

Pendorong (3 February 1955), speaking for the PKI and Communist-oriented peasant unions, took the Minister severely to task for having come out in defense of the autochthonous population. The distinction between autochthonous and nonautochthonous population was branded as a technique of the old colonial policy of divide and rule - a distinction as alien to the farmers themselves as one based on religion or political conviction. To argue historical right on the part of the rakyat penunggu was neither objective nor convincing and could lead only to greater discord. "It would be more tactical were the minister to draft a democratic national agrarian law which would be favorable to the farmers and would strengthen the position of our State than to rake up old questions which no longer represent a problem for our people."

Mimbar Umum (4 February 1955), a paper speaking for the autochthonous population, interviewed Chief Justice Mahadi of the provincial court about his reaction to the Minister's remark. Mahadi, a native son of East Sumatra, was delighted with the Minister's statement and fully shared his view that the agrarian problem in general and the jaluran issue in East Sumatra were not to be handled casually and locally but required an integral examination for the whole of Indonesia.

R. Tampubolon, chairman of Parkindo for the Kabupatan DeliSerdang, wrote a letter to the editor of Mimbar Umum (7 February 1955) protesting Minister Gusti Gde Rake's criticism of the state commission for its failure to acknowledge the special agrarian rights of the local population. Tampubolon, a Toba Batak, defended his party's letter of 10 April 1954 asking the state commission to treat all elements of the population alike and called attention to the fact that not only had the jaluran system been abolished by the agreements of 1951 but the abolishment of the jaluran system had been confirmed specifically by the Governor of North Sumatra in a letter dated 23 May 1952.

Nolen called on the Minister during the latter's visit to Medan but was hardly given a chance to express his views. Instead, the Minister elaborated extensively on his own ideas, which Nolen found utopian: establishing compact village communities with good access roads to the main highways, beautiful houses, wellstocked shops, barber shops, and the like. ${ }^{1}$ The Minister became 
lyrical in his description of the harmonious relationship there would be between Indonesian peasant and foreign planters. Nolen tried to bring the conversation "back to earth" by adverting to the notoriously poor use of land by the practically "nomadic" East Sumatran farmer. Gusti Gde Rake paused just long enough to admit Nolen had touched on a possibly troublesome characteristic of the people and to instruct his secretary to forward a request for an increase in agricultural extension work to the Minister of Agriculture.

The first real opportunity Nolen got to present the AVROS position was a question as to whether the planters were willing to make sacrifices in order to create adequate living conditions for the peasant population. Nolen forthwith recalled the planters' many cooperative actions - the return of over half of the former tobacco concessions, the local arrangements made by specific plantations, the financial assistance which the tobacco companies had given to the provincial government when Governor Abdul Hakim was in office - all representing sacrifices the planters willingly undertook on the government's promise of a permanent solution of the land issue. So far nothing had been done for the planters and even the proposed concentration of widely scattered squatters could provide a solution, Nolen explained, only if at the same time all new attempts at illegal squatting were stopped energetically. The planters stood ready to cooperate with the government by making land available or, short of financial contributions, by any other means consonant with their interests.

Nolen was somewhat surprised to find, as the discussion shifted to the "jaluran issue", that Gusti Gde Rake appeared to regard the jaluran rights as still valid on the basis of the concession agreements, though, as Nolen pointed out, the jaluran system had been discontinued with the partition of the tobacco lands in 1951 - an interpretation accepted by the government in principle despite annual ad hoc extensions at the request of provincial authorities. Nolen then brought up the matter of the frequent violent clashes between the autochthonous population and groups of laborers and squatters, but Gusti Gde Rake's only reaction was to remark that all this would end if the harvested tobacco fields could be distributed quickly and without much fuss. Nolen countered that the government had usurped from the planters their right of disposition over the harvested tobacco fields and compounded the abuse by distributing the fields among people who, in the eyes of the planters, had no claims on this land. The planters would prefer that the executive organs of 
the government recognize their agrarian rights and let the validity of any claims be examined in court. To this the Minister retorted that it was the planters' duty to contribute to the solution of the postwar problems, adding that "many latent sentiments" were alive among the people. The thinly veiled anti-planter reference was not lost on Nolen, whose report reads: "In an angry mood I dropped this topic after I had called the Minister's attention to the fierce press reaction to his remarks about the superior land rights of the autochthonous population of East Sumatra". 2

The Minister then turned to the Report of the State Commission, commenting that very little had been achieved for a year's work but the recommendations of Section I were good and should be carried out without delay. For his part, Nolen concluded with one last reminder of the urgent need for a forceful stand against illegal squatters.

An AVROS memorandum which Nolen had handed to Minister Gusti Gde Rake detailed incidents of destruction of plantation property between November 1954 and 4 February 1955 and cited as the reasons for persistence of the squatter problem the time lag between a police report of illegal squatting and trial, the practice of allowing squatters to keep illegally occupied land pending trial, and the authorities' hesitant policy in dealing with organized mass invasions of estates by squatters. That the spreading squatter problem had a demoralizing influence leading to serious cases of sabotage was substantiated with several recent examples of loss: on the Estate Bekalla of the United Deli Company no less than 40,000 newly planted rubber trees had been destroyed; on Estate Sungei Mangkei 1,500 newly planted oil palms and on Estate Tanjung Garbus no less than 8,000 young rubber trees had been uprooted from seed gardens; and elsewhere teak stands had been cut down and drainage systems, ruined by the construction of dams, had flooded out of control over estate lands. Nolen's report to AVROS characterized as "really disappointing" the Minister's vague promise of "a thorough investigation".

Ever since the completion of the Report of the State Commission in November 1954 and its formal submission to the cabinet in December, the planters of East Sumatra had been on the lookout for reactions and actions on the part of the government but so far, even from the visit of Minister Gusti Gde Rake in early February, it had proved impossible to find out anything. On 6 April, J.E. Demper, the AVROS representative in Jakarta, had occasion during a visit in the Ministry of Agrarian Affairs to question Singgih about news on the agrarian issue. As his letter of 
7 April to Medan reported, Demper could get Singgih to say only that the cabinet would probably accept the recommendations of the State Commission, and that the KPPT in Medan might be replaced by an agrarian office coming directly under the Ministry of Agrarian Affairs in Jakarta rather than under the Governor of North Sumatra. There was nothing in Singgih's remarks to indicate early action. At the annual meeting of AVROS on 29 April, Nolen gave his opinion that the general reticence of Singgih and other officials augured no important action until after the September elections and thereupon announced his departure for the Netherlands 30 April for consultations with the directors of the leading plantation companies. Nolen expected to be back in Sumatra by 20 May.

Whether by coincidence or by design, the Ministry of Agrarian Affairs sprang its great surprise, a draft of a decree for redistribution of estate lands in East Sumatra, within days of Nolen's departure and set as the deadline for a final answer 20 May, the scheduled date of his return. It turned out that Singgih had earlier been instructed by Minister Gusti Gde Rake to draft this decree for the solution of the agrarian problem on the basis of Emergency Law No. 8 inasmuch as without legal machinery all negotiations had failed. Singgih's draft incorporated most recommendations of the State Commission.

The just finished draft in hand, the Minister of Agrarian Affairs on May 3 appointed Singgih the representative of the government for the important assignment of presenting and securing approval of the decree draft in Medan by the 20 May deadline. At this point Singgih developed an intriguing strategy of timing and secrecy. Despite the early deadline he stayed in Jakarta until 9 May, delayed the setting of a first meeting with peasants and planters until 11 May, but kept the agenda a deep secret. Demper, the AVROS representative in Jakarta, could not find out why Singgih was visiting Medan, nor could the acting chairman of AVROS elicit any information even in response to a direct questioning of Singgih upon the latter's arrival at the Medan airport. Not until Singgih opened the meeting did the participants learn why they had been called together. In a somewhat brusque manner Singgih distributed copies of the draft decree among the members of the State Commission, with Rozendaal and Van der Molen substituting for Nolen and Vorstman, also in Europe, with the announcement that approval or disapproval must be in his hands within one week so that their reply could be brought to the attention of the Minister by 20 
May. In case both parties, planters and peasant unions, should approve the draft, the Minister intended to have it co-signed by the ministers of Agriculture, Economic Affairs, Internal Affairs, and Justice, and have it issued as a joint decree. In case of rejection the Minister would make use of Article 6 of the Emergency Law No. 8 and recommend issuance of the draft as a joint decree of the five ministers. It was obvious that the purpose of timing and secrecy was to give the planters as little time as possible to organize opposition. Singgih did not expect any difficulties from the side of the peasant unions.

What the startled participants at the 11 May meeting found before them was a decree draft which called for a drastic policy change. Minister Gusti Gde Rake and Singgih had developed a new strategy of sub-dividing estate lands piecemeal - estate by estate and district by district - being fully aware that this would greatly strengthen their position and give them an opportunity to excise larger portions of estates under supporting pressure from the peasant unions involved. In all previous negotiations the tobacco industry and the other industries had formed solid fronts and had insisted on an integral or overall, industry-wide settlement of the land issue, realizing full well that this procedure was to their advantage. The decree draft called for the establishment of an Office for the Reorganization of Land Use, or Kantor Reorganisasi Pemakaian Tanah (KRPT) working directly under the jurisdiction of the Ministry of Agrarian Affairs. This office was to investigate the agrarian situation in a given area and to decide which lands were to return to the state and which were to remain at the disposal of the estate. Categories definitely to be returned to the government embraced: land on both sides of roads maintained by local or provincial authorities, to a depth of 250 meters measured from the middle of the road; land which had been occupied by permanent settlements prior to 1950; and land which had served as permanent wet rice fields prior to 1950 . Some exceptions were anticipated but only where it could be proved that an estate needed certain parcels of land falling into these categories for its rational operation.

By way of indemnity the planters were to receive 30-year leases for the land remaining in their possession, with extensions up to 20 years possible under special circumstances. These long leases were to be replaced by new agrarian rights if and when a new agrarian law was issued. A discordant note for the planters, however, was the provision for evacuation of reassigned land which gave planters two months to vacate land returning to public 
domain but set no time limit for squatters on land remaining in estates.

Widely dispersed squatters were to be brought together in new compact settlements and squatters were to be divided into three categories with the following land allowances: (1) those who preferred to make their living as farmers, 2 hectares; (2) those who preferred to move to land within the belts along the main roads, 0.5 hectare; and (3) those who wished to move to the towns, 0.4 hectare. The remaining provisions ensured for the squatters free transportation, Rp. 1500 per family in assistance for the construction of new homes, indemnity for loss of plants at the old site up to Rp. 500 per family, an advance of Rp. 250 per month for five months to cover living expenses, and a single advance of Rp. 450 for the purchase of seed, fertilizer, and agricultural implements. The only significant deviation in the draft from the recommendation of the State Commission was the allowance of two hectares to the rakyat penunggu who had agrarian rights on the basis of the old concession agreements.

Though Singgih's surprise move had caught both sides unprepared to give quick approval, the planters' representatives made the more anguished requests for further time to study the decree draft, and the next few days saw heightened activities in the offices of AVROS. Cables and letters went off to The Netherlands, various memoranda were sent to the members of the executive committee as well as to all members, and the executive committee held daily meetings in order to work out a strategy for discussions with Singgih and for AVROS' formal reply that would stave off a final decision until Nolen's return from Europe.

On 13 May the executive committee of AVROS met to develop lines to be followed in the second meeting, later the same day, with Singgih. To avoid discussion of the draft decree itself, which all agreed was unacceptable on every point important for the planters, it was decided to ask for clarification of the judicial and factual guarantees as a necessary step before the planters would be able to give Singgih their answer. At the meeting Singgih left no doubt that the Minister of Agrarian Affairs intended to pursue a new policy and did not regard as binding either the previous agreements reached between government and planters or the subsequent arrangements and decrees of 1951. This alarmed the planters and made them still more reluctant to give any answer to Minister Gusti Gde Rake, and requests were made for an extension of the deadline to permit further discussions and for an appointment for the AVROS chairman immediately following his 
return from The Netherlands. Since the representatives of the peasant organizations had meanwhile accepted the draft decree, the planters found it politically wise to approve a pilot project of squatter resettlement as a constructive starting point for the ultimate settlement of the agrarian issue.

At a meeting the following day Singgih became extremely blunt, charging that the planters had so far registered nothing but objections and complaints and remarking that the government would appreciate a constructive contribution which would meet the expectations of the farming population. In their defense the planters cited again their voluntary return of about half the former tobacco soils and their willingness to return one-third of the perennial-crop lands. The 14 May meeting ended with a request that AVROS be permitted to submit a written statement before Singgih's departure for Jakarta and another appeal to Singgih to arrange an early appointment between the AVROS chairman and Minister Gusti Gde Rake.

The written statement from AVROS, prepared by the executive committee and addressed to Singgih as representative of the Ministry of Agrarian Affairs, deftly skirted the question of acceptance or rejection of the plan by saying the meetings of 11 , 13 and 14 May had raised several points whose ramifications for current and future capital investments would have to be explored. There followed a brief defense of the legal status of the 1951 agreements from their incorporation in the decrees of 28 June $1951^{3}$ and 28 September $1951^{4}$ to their confirmation in the Government Declaration of 25 August 1953 as binding for the deliberations of the State Commission. (The planters had noticed that the decree draft lacked any reference to the decrees of 1951.) The AVROS statement concluded with the suggestion that a trial resettlement of squatters be undertaken before adoption of a final plan since such a project might furnish valuable practical data. This was handed to Singgih just prior to his departure from Medan on 16 May. ${ }^{5}$

One day later copies were sent to the representative of AVROS in Jakarta with the request that he call on the secretary-general of the Ministry of Agriculture, Gunung Iskander, and two other high officials in the Ministry, Kasimo and Amien, as well as the Governor of the Bank Indonesia. His instructions were to let these selected officials read the AVROS statement, being careful not to leave a copy with anyone or allude in any way to the planters' probable answer to the Minister of Agrarian Affairs regarding acceptance or rejection, to sound out potential support 
elsewhere in the government for modification of Singgih's plan. On 19 May 1955, to meet the deadline, AVROS sent a letter ${ }^{6}$ to the Minister of Agrarian Affairs explaining that the planters would be in a position to give their answer only after clarification by the Minister of the status of the 1951 agreements and of the duration of the long leases proposed as exchange for the old concession agreements. On 26 May Singgih replied in the name of the Minister of Agrarian Affairs ${ }^{7}$ with a repetition of familiar responses: that the decree draft reflected the cabinet's decision to solve the problem of the use of estate lands by the population of Sumatera Timur on the basis of Emergency Law No. 8/1954, that previous agreements remained valid in principle but would be superseded if necessary for the greater good, and that the long leases would normally be written for 30 years with extensions to 40 or 50 possible under special circumstances.

Nolen, back from his consultations with plantation company directors in The Netherlands, answered Singgih in a letter (No. 803) dated 31 May which, in addition to stressing the planters' dependence for security of operations on government faithfulness to the existing agreements and their concomitant objection to new demands for the return of unstated amounts of land, took up a number of other objectionable points in the decree draft. These included the provision giving planters two months to vacate reassigned land versus no time limit for squatters and the provision that all squatters could claim land. Nolen summed up the attitude of the planters as dissatisfaction over the omission of a number of basic guidelines agreed upon in the past and the inclusion of several points which in their present form were unacceptable but, still postponing an answer, ended his letter by saying the plan required further study and discussion since it dealt with topics which had far-reaching consequences for the future.

In the course of a conversation with Nolen on 2 June, Singgih mentioned Minister Gusti Gde Rake's recollection that Nolen had not only expressed approval of the Minister's plans during their February conference but had assured material support from the planters. Backing up his immediate oral denial, Nolen next day wrote to the Ministry of Agrarian Affairs emphatically denying any promise that planters would be willing to undertake mechanized land clearing prior to the transfer of squatters, though he recalled having considered it possible that companies might make transport equipment available for squatter transfer. As to the squatter problem in general, Nolen added, squatters by the 
thousands continued to occupy estate lands, despite the existence in East Sumatra of extensive areas of public domain, because of the ineffectiveness of police and provincial authorities and because of the promise of compensation and credit as well as free preparation of land. ${ }^{8}$

An appointment with Minister Gusti Gde Rake on 7 June 1955 started off poorly when Nolen was made to wait over an hour while the Minister concluded a conference with Singgih. Even then as Nolen reported to the executive committee of AVROS, Gusti Gde Rake for the first half hour cut short with stiff and unreasonable answers talk on every topic Nolen brought up, not "changing his tune" until the conversation veered to the fact that the cabinet would fall without positive results on the agrarian front. For this reason Gusti Gde Rake insisted it was very much to be regretted that the planters were not willing to cooperate in the clearing of land to be assigned to squatters. With the comment that it had been the mistake of previous cabinets to attempt resettlement of squatters without preparation of sites, the Minister insinuated that the more the planters cooperated with the government the more consideration their interests would receive. Nolen in turn tried to explain why the planters could not cooperate in the way Minister Gusti Gde Rake expected and why the government, by pampering the squatters, itself encouraged their refusal to move. Past experiences with squatters, Nolen said, indicated that Gusti Gde Rake's new plan could only result in further land losses for the planters without any improvement of the squatter problem.

Although aware that his arguments had failed to alter Minister Gusti Gde Rake's position and that Singgih was proceeding with the draft of a decree, Nolen submitted still another letter ${ }^{9}$ to the Ministry of Agrarian Affairs. This one, far longer than those of 19 and 31 May was not limited to strategic arguments on a few points but ranged over the whole draft decree, summarizing reactions to practically every provision. The letter stated the planters' conclusion that a joint decree based on Article 6 of the Emergency Law No. 8/1954 could never produce a solution of the land issue in East Sumatra. The problem could never be solved so long as one approached it only by shifting squatters within the plantation region and did not develop free public domain. Since the draft stated specifically which lands were to be surrendered by the estates it was unjust not to specify which lands were to remain under control of the planters. Nolen, therefore, asked for a clear policy statement that the estates would retain: (1) to- 
bacco lands which had been assigned to the estates on the basis of the partition of 28 September 1951 and which by 27 August 1953 had not yet been taken over by squatters; (2) tobacco land which could be regained through transfer of squatters; and (3) perennial-crop lands essential to the rational operation of the estates, these estates having agreed to return a maximum of 220,000 hectares with the understanding that compensation from the public domain of economically exploitable land would be made for any amount in excess of 180,000 hectares.

Referring to the draft's stipulation that land along both sides of all public roads be surrendered, Nolen predicted new unchecked waves of illegal squatting. Assuming that the plantation belt had approximately 4,300 kilometers of publicly maintained roads with an estimated 60 percent of the land on either side of the road under cultivation, this stipulation would lead to an additional loss to the estates of 86,000 hectares of cultivable soil, enough to take care of 172,000 families (since the lots next to the roads were to measure only 0.5 hectares) or several times more than the total number of squatters having an interest in such lots. In this connection Nolen called again for a registration of all squatters on the basis of their right to a land assignment and exclusion therefrom of estate laborers, land speculators, tenants on squatted land, new squatters who had violated the 27 August 1953 standfast, and those who were not Indonesian citizens. (This last was directed against alien Chinese squatters.)

Nolen maintained that promises of support of squatters would make the agrarian problem very difficult and would postpone a solution for years. So long as squatters occupied a preferred position, there would be no end to new illegal land occupation. In a final paragraph Nolen expressed the hope that the Minister of Agrarian Affairs would not invoke the provision under Emergency Law No. 8/1954 (Article 6) for an imposed settlement by ministerial decree because only "an integral and voluntary settlement could in the opinion of the entrepreneurs produce a solution".

Minister Gusti Gde Rake did not interrupt Singgih's work on the joint decree. Demper, the AVROS representative in Jakarta, redoubled his lobbying efforts and took copies of the letter to key officials in the Ministry of Agriculture who might be persuaded to keep the Minister of Agriculture from signing the decree. It was to no avail. On 30 June 1955 the ministers of Agrarian Affairs, Agriculture, Economic Affairs, Internal Affairs, and Justice signed Joint Decree No. 1/1955, which differed only 
in some minor details from the draft plan of May 1955 although the AVROS objections had been taken into account at least partially, notably the demand for references to previous agreements and decrees of 1951 (with the proviso, however, that the government felt not bound by them).

The decree itself was prefaced by a justification for its enactment, with references to Minister Gusti Gde Rake's actions in May and to the futile efforts of Singgih to obtain acceptance of the draft plan by the representative of the plantation industry whereas those of the peasant unions had accepted all its major provisions. The government, therefore, felt compelled to establish the main guidelines for a concrete and permanent settlement of the question regarding the use of estate land in East Sumatra. Specifically, the agrarian problem would be solved gradually, i.e. estate by estate and district by district, taking into consideration the interests of the population and of the estates as well as the practical possibilities of settling the issue. To handle this and to take the place of the former KPPT, which had been in operation since the days of Governor Abdul Hakim, a new agency, to be known as the Office for the Reorganization of Land Use in East Sumatra, or Kantor Reorganisasi Pemakaian Tanah Sumatera Timur (KRPT), assisted by a Council of Assistance, or Badan Pembantu, would be established with a chairman plus representatives of six government agencies and six peasant unions. Previous agreements regarding the tobacco estates and the perennial-crop estates would be used as the "starting point" for the determination of the new boundaries between estates and public domain but, should it prove necessary, more plantation area would be designated public domain and the respective estates given other land as compensation. The provisions identifying the lands to be returned to the government, authorizing a registration of the squatters, and stipulating the amounts of land and types of support squatters being resettled would receive were identical with those in the earlier draft.

There were three implemental decrees issued by the Minister of Agrarian Affairs simultaneously with the Joint Decree: Decree No. Sk. $102 / \mathrm{Ka} / 1955$ creating the KRPT, which was to have its seat in Medan but was to come under the direct supervision of the Minister of Agrarian Affairs; Decree No. Sk. 1 v3/Ka/1955 furnishing technical guidelines and instructions for the partition of the land and the resettlement of the population; and Decree No. Sk 104/Ka/1955 establishing the Council of Assistance (Badan Pembantu Pemakaian Tanah Sumatera Timur). 
On 24 July 1955 the Ali Sastroamidjojo Cabinet resigned, though remaining as a caretaker cabinet until the installation of the Burhanuddin Harahap Cabinet on 12 August. During this political lull neither the Ministry of Agrarian Affairs nor AVROS took any significant action. But on 1 August the Governor of North Sumatra presided over the official discharge of the State Commission and the dissolution of the KPPT, following which the Secretary General of the Ministry of Agrarian Affairs formally created the new KRPT with Imam Supangat as head of a staff largely taken over from the old KPPT. Several Medan newspapers criticized the appointment of Imam Supangat because of his lack of familiarity with the problems of East Sumatra and also expressed considerable pessimism about the new agency's prospects for solving a problem involving an estimated 120,000 squatter families by means of the proposed annual resettlement of only 1,000 .

Thus the planters, especially AVROS, were faced with new ministers and advisers to be evaluated and approached. In a memorandum addressed to the AVROS executive committee, Nolen assessed the changes, noting that Gunawan, the new Minister of Agrarian Affairs, who like his predecessor belonged to the PRN, was of higher caliber than his predecessor and that two other new ministers, Kasimo and Hakim, had an excellent insight into the woes of East Sumatra. I.J. Kasimo, the new Minister of Economic Affairs, had authored a perceptive report on East Sumatra in 1950 and more recently had been head of the Service on Plantation Agriculture (Jawatan Perkebunan) in the Ministry of Agriculture. Abdul Hakim, serving in the new cabinet as Minister of State without portfolio, had of course been Governor of North Sumatra. Nolen felt that both I.J. Kasimo and Abdul Hakim could be counted on for advice and even expressed a faint hope that the new cabinet, since several members were known to be critical of the agrarian policy of the previous cabinet, might revoke the Joint Decree. ${ }^{10}$ Nolen therefore proposed continued strong opposition to Emergency Law No. 8/1954 and to the Joint Decree. The executive committee concurred and approved the submission of a new AVROS memorandum detailing the legal objections to the Joint Decree. ${ }^{11}$ The memorandum declared, following a minute examination of the five ministers' action against the provisions of Emergency Law No. 8, that the Joint Decree was illegal because:

1. the conditions which would have justified such a joint decree on the basis of Article 6 had not been present; 
2. the specific instructions of Article 2, Section 3 had not been carried out as equitably;

3. the decree did not carry out instructions stipulated in Article 7 ; and

4. the decree included land not covered by Emergency Law No. 8.

A conversation with Minister Gunawan in early September gave Nolen the impression that the new minister did not approve the agrarian policy of the previous cabinet, further strengthening Nolen's hope in the possibility of a withdrawal of the Joint Decree. Taking advantage of the opportunity, Nolen promised Minister Gunawan at least two background memoranda - one analyzing the application of Emergency Law No. 8 of $1954^{12}$ and one summarizing the changes in government agrarian policy from 1950 to $1955 . .^{13}$ The first memorandum became an extensive charge, with documentary support, of the lax enforcement of the 12 June 1954 standfast set by Emergency Law No. 8 and an explanation of how this affected plantation operations and the agrarian situation. As to enforcement, a clear example was the time lag between the preparation of an official police report and the completion of the trial and pronouncement of sentence. The memorandum cited the case of a group of squatters from the village of Tanjong Balei Sidomuljo near the estate of Bekiun. Although these men were accused on 14 September 1954 of having violated the standfast, the first court hearing did not take place until almost seven months later, on 4 April 1955, in Binjai. This had been followed by hearings on 17 and 18 May, 18 and 23 June, 9, 13, and 25 July and 22 August with the next, and predictably as inconclusive, hearing scheduled for 3 October. All the while the squatters continued to hold portions of the Bekiun Estate illegally, reinforcing the conviction of squatters everywhere that the courts would be lenient. Very few judges, in fact, had handed out the maximum penalty permitted by the law (see Table 10). Furthermore, nine out of ten accused would appeal even a light sentence and thus still further postpone their departure from squatted land. The planters noticed that most authorities were even less disposed to enforce the law against mass invasions by organized groups.

On the subject of plantation operations, the memorandum stated that rejuvenation of estates by new planting had been precluded in many cases because the necessary land was occupied by squatters. Table 11 lists several estates in the kabupaten of 
Table 10

Sentences issued by the courts of East Sumatra (1955)

\begin{tabular}{|c|c|c|c|c|}
\hline Court & Date & $\begin{array}{l}\text { No. of } \\
\text { Squatters }\end{array}$ & Penalty & Estate \\
\hline Medan & 12 July & 11 & $\begin{array}{l}\text { One month of conditional } \\
\text { jail sentence with six } \\
\text { months probation }\end{array}$ & $\begin{array}{l}\text { Bandar } \\
\text { Chalipah }\end{array}$ \\
\hline Medan & 12 July & 7 & $\begin{array}{l}\text { One week of conditional } \\
\text { jail sentence with six } \\
\text { months probation }\end{array}$ & Saentis \\
\hline Medan & $25 \mathrm{Oct}$ & 72 & $\begin{array}{l}\text { Five days imprisonment } \\
\text { served by five days spent } \\
\text { in custody }\end{array}$ & $\begin{array}{l}\text { Bandar } \\
\text { Chalipah }\end{array}$ \\
\hline Medan & $10 \mathrm{Nov}$ & 110 & Fine of Rp. 10.- & Helvetia \\
\hline $\begin{array}{l}\text { Lubuk } \\
\text { Pakam }\end{array}$ & Oct & 180 & $\begin{array}{l}\text { Ten days conditional } \\
\text { jail sentence with three } \\
\text { months probation }\end{array}$ & $\begin{array}{l}\text { Batang } \\
\text { Kwis }\end{array}$ \\
\hline Medan & $22 \mathrm{Nov}$ & 155 & $\begin{array}{l}\text { Six days imprisonment } \\
\text { served by the fact that } \\
\text { group was in custody for } \\
\text { six days }\end{array}$ & $\begin{array}{l}\text { Bandar } \\
\text { Chalipah }\end{array}$ \\
\hline
\end{tabular}

Source: AVROS, Memorandum inzake de berechting van onwettige occupatie op grond van de Noodwet No. 8/1954 (Medan, 26 November 1955). Also issued as an appendix to letter No. 229/Bl. (Medan, 30 November 1955).

Deli-Serdang and Simelungun and shows the magnitude which squatting had reached there. In every instance more than onethird and in one almost 60 percent of the land could not be utilized by the estate company. A number of tobacco estates no longer had enough land to maintain a rotation of the desirable length, just as rubber and sisal estates of ten were unable to bring their crop area up once more to the capacity of the factories. The resulting financial losses were felt not only by the management but also by the public treasury. The planters were convinced, the memorandum noted in conclusion, that the situation could only 
Table 11

Estates in the kabupaten Deli-Serdang and Simelungun and the extent of illegal occupation

\begin{tabular}{llcrc}
\hline Name of Estate & Crop & $\begin{array}{c}\text { Total Area } \\
\text { (hectares) }\end{array}$ & $\begin{array}{r}\text { Squatted Area } \\
\text { (hectares) }\end{array}$ \\
\hline Bah Lias & Rubber & 6,749 & 2,316 & 34.3 \\
Laras & Sisal & 8,461 & 3,351 & 39.6 \\
Rambutan & Rubber & 13,330 & 6,344 & 47.6 \\
Mata Pao & Oil palm & 3,636 & 1,680 & 46.2 \\
Bekalla & Rubber & 9,164 & 4,094 & 44.7 \\
Medan & Tobacco & 1,529 & 727 & 47.5 \\
Bandar Chalipah & Tobacco & 3,642 & 1,369 & 37.6 \\
Kwala Namu & Tobacco & 4,282 & 2,502 & 58.4 \\
Pagar Marbau & Tobacco & 5,032 & 1,872 & 37.2 \\
\hline
\end{tabular}

Source: Memorandum inzake de Uitvoering van de Noodwet No. 8/1954 (Medan, 6 September 1955).

be corrected provided: that steps be taken not only against individuals who violated the law but also against large organized bands of squatters; that the police authorities not limit themselves to the drafting of reports to the public prosecutors but also take the necessary steps to expel the squatters from the land; and, finally, that illegal occupants quickly be brought into court and given sentences more in line with the law.

The second memorandum to Minister Gunawan, tracing the agrarian policy of the various cabinets between 1950 and 1955, described the Natsir, Sukiman, and Wilopo Cabinets as having aimed to create a flourishing smallholder agriculture without harming plantation agriculture through a return of all those estate lands not truly needed for the operation of the estates in exchange for new agrarian rights which would protect the interests of both planters and small farmers. Successive cabinets had accepted the principle that an integral rather than partial or fractional solution of the land problem be sought and that neither the problem of the return of land nor the squatter problem should be approached by individual estates. There followed a lengthy summary of the negotiations leading to the 1951 agreements as well as a repetition of the planters' complaint that the government had defaulted on the agreements by its failure to issue new rights or otherwise honor its commitment. Then the 
Ali Sastroamidjojo Cabinet, after having initially acknowledged the earlier agreements as at least a starting point, had reversed itself in mid-1954 and with the promulgation of Emergency Law No. 8 abandoned entirely the principle of an integral settlement in favor of a peasant-oriented settlement estate by estate and district by district. The "illegal" Joint Decree of 30 June 1955 merely confirmed this arbitrary dismissal of the earlier agreements with the planters. The unexpressed hope of the memorandum was that the Burhanuddin Harahap Cabinet would reject the policy of its predecessor.

While presenting to Minister Gunawan yet another memorandum on 19 October 1955, AVROS delegate Demper got the first indication of a reaction to the AVROS memorandum of 29 August with his discovery that the cabinet had flatly rejected the AVROS arguments and fully intended to continue the policy initiated by the preceding cabinet. Any lingering hope of a policy reversal was finally dashed by the installation on 23 November of the Council of Assistance (Badan Pembantu) to KRPT called for by Minister Gusti Gde Rake's decree No. Sk. 103/Ka/1955. Minister Gunawan did make one minor concession in the decree by requiring the Council of Assistance to call on AVROS for advice in matters of concern to the planters, but the utter failure of AVROS efforts to win his support was manifest in his endorsement of the demands of the autochthonous population for a continued issuance of jaluran at the end of the tobacco harvest.

Minister Gunawan instructed the KRPT to speed up the registration of the squatters, to survey the squatted areas, and to be ready for the resettlement of the first one thousand families immediately after the elections in mid-December. A KRPT directive in late November notified AVROS that thirteen field teams would be dispatched to various parts of East Sumatra to conduct another registration of the squatters and asked for the cooperation of the plantations.

In a review of developments during 1955 at an extraordinary AVROS membership meeting on 28 December, Nolen described the agrarian situation as extremely confused and spoke of an impasse on the agrarian front. He noted that the Burhanuddin Harahap government had demonstrated its inability to protect unoccupied land against new invasions and, possibly because it felt its days were numbered, had showed no initiative in the handling of the agrarian problem. Nolen estimated that the tobacco companies had lost 3,000 hectares since the latest standfast of 12 June 1954. While some police authorities were willing 
to oppose new invasions by civilians, nowhere were police prepared to investigate cases of illegal land grabbing by Indonesian soldiers and veterans. Nolen also reported a growing "sale" of estate lands for building purposes by squatters in the neighborhood of Medan and other urban centers to nonfarmers, businessmen, and even government officials. These lands were too exhausted to be any longer of agricultural use to the squatters but their value had risen sharply because of a shortage of residential sites. Squatters negotiating the sale of "their" land already had their eyes on other parcels of estate lands.

Nolen urged the members of AVROS to maintain a united front and above all to avoid the temptation of making local arrangements for the transfer of squatters from critically located parcels to land on the fringe of a plantation that the management was ready to release anyway. The reason for his warning was that under prevailing conditions there was no way of protecting the vacated land against renewed invasion by a new group of squatters.

Nolen concluded with some remarks on the Dutch-Indonesian negotiations just opened in the Hague on 10 December at the request of the Indonesian cabinet and transferred to Geneva on 16 December so that the negotiations would be conducted in neutral territory. The agenda of the conference included dissolution of the Netherlands-Indonesian Union, cancellation of the financial and economic agreements concluded at the Round Table Conference in 1949, a decision on the future of West Irian, and any other matter either side wanted to introduce in furtherance of better relations between the two countries. The planters feared that their future would be jeopardized by the unwillingness of the Dutch government to meet the Indonesian demands regarding West Irian and by late December, as I know from personal observations, their pessimism dominated their conversation everywhere in East Sumatra. It was of course precisely an impasse on financial and economic matters and the West Irian issue that brought the conference to a premature end on 11 February 1956. On 21 February Indonesia withdrew from the Netherlands-Indonesian Union and canceled all financial and economic agreements attached to the Union Statute.

\section{The Agrarian Struggle in 1956: Old and New Problems}

The AVROS agrarian committee met in January 1956 to reexamine AVROS strategy vis-a-vis Emergency Law No. 8/1954. 
Loopholes for squatters had become evident: in the law's imprecise statement of estate rights to land, which could be construed as preventing planters from using land not actually under cultivation by squatters on 12 June 1954; and in the definition of illegal occupation as not only "actual occupation, cultivation and/or control of a piece of estate land" but additionally as "maintenance of crops or structures on the land, irrespective of whether the person involved actually lives on the land or uses the structures", which had opened the door to a new kind of claim. Several court tests had been made in which squatters claimed three or more times their area of actual cultivation, contending that the additional land, though lying fallow on 12 June 1954, had been cultivated by them prior to the standfast and was therefore under their control in the spirit of the law. Some judges had accepted this argument. Furthermore, squatters who possessed registration cards proving occupance on 12 June 1954 were claiming the right to plant trees, to convert the land into sawah, to replace temporary shacks by permanent buildings, and even to sell the land.

The planters maintained that the squatter had the legal right only to cultivate annual crops until the land dispute should be settled. It was agreed that AVROS should urgently press the government to close the loopholes in the law, especially since the squatters would certainly demand compensation for their immovables and improvements, whatever their legality, in the event of resettlement. ${ }^{14}$

Meanwhile, however, delays in the replacement of several key officials who had been transferred had created a "vacuum in authority" (gezagsvacuüm) which gave lower ranking officials the convenient excuse for inaction of having to wait for further instructions. ${ }^{15}$ Then in early March the Burhanuddin Harahap Cabinet resigned and was succeeded on 26 March 1956 by the second Ali Sastroamidjojo Cabinet, a PNI-Masyumi coalition. Governor Amin was transferred to Jakarta in April and Sutan Kumala Pontas was named acting governor of Sumatra in his place. These changes meant that the AVROS staff had to spend a great deal of time presenting the planters' case all over again to a new governor and a new minister.

Also slowing progress toward a solution, as the planters would soon discover, was the surge of nationalist feeling following abrogation of the Netherlands-Indonesian Union and of the financial and economic agreements of 1949. The labor and peasant unions were quick to take advantage of the change in 
attitude toward Dutch enterprises in Indonesia, passing resolutions to urge that the government's new freedom of action be used for a sweeping revision of agrarian policy that would at last answer the peasants' need for land and end their struggle with poverty. ${ }^{16}$ They demanded that no concessions be renewed and that instead those estates whose concessions had expired be thrown open to land-hungry peasants. By March the BTI and other peasant organizations were organizing mass invasions, specifically of those tobacco estates having lapsed consessions.

By now estates with expired concessions had a tenuous legal status. Under the terms of the tobacco-land partition of 1951, planters had been granted ad hoc thirty-year extensions of expiring concessions subject to subsequent legalization. But five years had now gone by without the promised new agrarian law, and the planters still had no better recourse in court than to present expired contracts and refer to the minister's and governor's decrees of 28 June and 28 September 1951 as their authorization for continued use of and control over these estate lands. The lawyers maintained that the companies had at the proper time asked for extensions of the concessions and that the government had not refused these requests, in fact had continued to collect the annual hasil tanah in anticipation of the new legal formulation of agrarian rights. Although some East Sumatran judges accepted this line of reasoning, others refused to sentence squatters on the basis of Emergency Law No. 8/1954 in cases where the concession had expired. AVROS lawyers for their part were reluctant to suggest prosecution on the basis of Ordinance No. 110 of 1948 which protected free public domain under control of the central government or self-governing lands, because to have done so would have implied that the expired concessions had reverted to the public domain - which they clearly had not - thereby providing their opponents with such possibilities as presenting the planters themselves as squatters. Obviously the legal position of an estate with a valid concession agreement was stronger than one with an expired contract. This the BTI lawyers had recognized and were using in their defense arguments. ${ }^{17}$

Their prospect of judicial victory small, and diminished daily by rising political tensions between Indonesia and The Netherlands, AVROS planters and their lawyers decided to shift from legal to economic lines of reasoning. Now they concentrated on the important economic contribution plantations were making to both the national and the local economies in foreign exchange, taxes, and direct and indirect employment. They stressed the grave 
danger to a continuation of this contribution to the people's general welfare unless the tobacco lands between the Wampu and Ular rivers were restored to plantation operations. The United Deli Company and the Senembah Company both announced that it would be necessary to close several of their tobacco estates by the end of 1956 or at the latest 1957 unless all squatters who had entered those estates since June 1954 were promptly removed.

Soon laborers began to show concern for their jobs and antiCommunist Medan newspapers came out with statements by antiCommunist labor leaders accusing BTI organizers of purposely directing their followers to tobacco estates whose laborers belonged to socialist or religiously oriented labor unions. Tangkas (5 April 1956) quoted a charge by M.J. Rangkuty, the secretary of OBSI - a socialist labor union affiliated with the Indonesian Socialist Party (PSI) - that the BTI was deliberately concentrating on such estates as Timbang Langkat, Sungai Mencirim, Tandem, and Klumpang where the laborers were not affiliated with Communist unions and, furthermore, that the squatters were being recruited in North Tapanuli with payments of Rp. 200 per person and brought in two or three hundred at a time for mass invasions of target estates. Rangkuty's charge was vehemently denied by L. Darman, first secretary of BTI for North Sumatra, who accused Rangkuty of acting more like an AVROS mouthpiece than a labor leader. Darman maintained that a desperate land hunger, not BTI instigation, was driving the North Tapanuli squatters into East Sumatra and that their land needs could be met by government redistribution of unused portions of the estates. Such action, Darman asserted, would have the further recommendation of greatly reducing the need for rice imports into East Sumatra, perhaps even making possible exports of rice to other parts of Indonesia, and thereby helping to implement the new cabinet's program for improvement of the life of the Indonesian farmer through expansion of the production area for foodstuffs and other commodities, especially outside Java. Quite clearly this agricultural program deserved the support of all Indonesian farmers, Darman concluded, and the government must act energetically to effect the return of all plantations held under lapsed concession agreements, turning management of these plantations over to the Government Estates Administration (PPN) or Indonesian entrepreneurs and parceling idle land to landless farmers. ${ }^{18}$

The next day Mimbar Umum (6 April 1956) carried an editorial charging Communist and Communist-oriented organiza- 
tions with having used the agrarian problem for their political purposes since before the elections of 1955, when the PKI had promised land to the voters in return for their political support. There followed a prediction that the rate of new squatter invasions would soon rise as the Communists worked to create tensions between PNI and Masyumi members in the new cabinet (the Masyumi Party had five ministers in the cabinet) in repetition of the strategy that had brought down the Wilopo Cabinet in 1953.

Other moderate editorials appeared warning of the consequences the closing of estates would entail. ${ }^{19}$ Mestika reasoned that every right-minded Indonesian would welcome the departure of the foreign planters and the continuation of their estates by Indonesians but that successful management of such large enterprises required time, capital, technical knowledge, and managerial experience. One must recognize, the editorial continued, that the effect of squatter damages was not restricted to the foreign entrepreneurs but that also the interests of Indonesian government, and therefore the people as well, would suffer. After stressing the taxes and foreign exchange the country gained from the foreign plantations, the Mestika editorial admonished: "So long as we Indonesians are not yet able to manage these foreign estates ourselves, it harms our people if the planters lose the possibility of continuing their operations". As the editorial writer put it, unless the government took a firm stand the so-called dollarland of East Sumatra would soon become bankrupt and lose its importance. ${ }^{20}$

If the planters were not too happy to have the moderates emphasize the economic value of the plantations and plead for their protection only to urge better preparation for an eventual takeover by Indonesians, BTI leaders had their own objections. S.M. Tarigan, secretary-general of the BTI board of directors for North Sumatra, answered the editorial writers of Tjerdas, Tangkas, Lembaga, Mestika, and other anti-Communist newspapers early in May 1956. Although conceding that large areas of former (expired) concession lands had been used by East Sumatran farmers for their own agricultural purposes, Tarigan denied that these farmers had harmed the estates and insisted that their activities were confined to land intentionally left in unused, neglected condition by the plantations. Any accusation to the contrary was provocative, unjustified, and, as was well known, attributable to foreign capitalists and their collaborators, who sought to cause discord. The renewed great activity of squatters for the expansion of their land Tarigan linked with 
cancellation of the RTC agreements, which in the past had enabled Dutch capital to monopolize hundreds of thousands of hectares of fertile land while hundreds of thousands of peasants could find no land whatsoever. The BTI insisted that expansion of the squatter-cultivated area was dictated by the threat of hunger and should be encouraged by the government as part of the second Ali Sastroamidjojo Cabinet's comprehensive new program for improving the standard of living of the Indonesian peasant. In fact, the recent arrests of peasants on the basis of accusations by Dutch planters were, as BTI saw it, in direct conflict with this new program. Tarigan offered the opinion that a solution to the agrarian problems of East Sumatra, now that Indonesia had gained freedom of action with the scrapping of the RTC agreements, could easily be agreed on if only all parties would show an understanding for the cabinet's program. Asked about the attitude of the BTI toward a strict enforcement of extant laws in order to solve the problems, Tarigan replied that measures such as those used by Governor Hakim not only were thoroughly damned by peasants and dangerous to implement but were in conflict with the cabinet's new program. Instead of arrests which, Tarigan argued, were no solution the BTI proposed a conference of the peasant organizations to discuss the matter of arrests, with all arrested farmers to be released pending new instructions from the central government. In the meantime, all parties should understand that "the farmers who cultivate estate soils are soldiers in the war against hunger". Tarigan then repeated the BTI demand, enunciated earlier by L. Darman, that the government take over all unused and intentionally neglected land as well as all estates with lapsed concessions, notably Bandar Chalipah, Binjai Estate, Bukit Melintang, Gedong Johor, Mabar, and Sungai Mencirim, arranging Indonesian management for the cultivated estate lands and distributing all uncultivated or reserve lands to the peasant farmers. ${ }^{21}$

During a visit to Jakarta in May 1956 Nolen discovered that the secretaries-general of the Ministries of Agrarian Affairs, Agriculture, and Justice as well as the director and assistant director of the Service for Estate Agriculture (Jawatan Perkebunan) in the Ministry of Agriculture were drafting an interministerial memorandum for the prime minister proposing a new statement by his office regarding the enforcement of Emergency Law No. 8/1954. The memorandum also recommended the addition of a note to all expired concession contracts of tobacco estates certifying their temporary extension. Stressing the urgency of 
immediate firm action, Nolen gave the Jakarta authorities these new squatter statistics: the tobacco estates alone had lost 2,500 hectares between 12 June 1954 and 31 December 1955 and no less than 6,210 hectares during the first five months of 1956 .

\section{Threat of a New Standfast}

But on 29 June the Medan newspaper Mimbar Umum made the alarming disclosure that discussions between the Resident of Sumatera Timur, A.M. Djalaluddin, and representatives of BTI, Petani, STII, and Badan Perjuangan Rakyat Penunggu had just been concluded with an agreement to recommend to the central government the declaration of a new standfast so long as the government had not yet reached concrete decisions regarding the agrarian problem of East Sumatra and the squashing of all court charges made against peasants involved in recent illegal occupations in return for which the peasants accepted a ban on any further expansion of the illegally occupied soils. Similar reports were published a few days later in Mestika (7 July) and other papers.

It is indicative of the strained relations between AVROS and Resident Djalaluddin that AVROS could not obtain an official explanation and had to draft its letter of protest on the basis of press reports. The main arguments which AVROS summoned against the idea of a new standfast were:

1. A post factum practical legalization of illegal occupations would only encourage squatters to ignore future bans. Above all, where the ban on illegal occupations was being violated systematically by large groups of squatters belonging to a certain peasant organization (BTI) the belief would arise that the government was powerless vis-à-vis organized opposition.

2. The past had shown that peasant organizations did not observe standfasts. Earlier standfast regulations had merely served to give violators impunity and to consolidate their gains in land so that every standfast had added to the size of the problem. 3. A new standfast would demonstrate again, as earlier ones had, that those who violated legal orders would be better off than those who obeyed the law.

4. Issuance of a new standfast would be interpreted as a clear recognition of the power of the peasant leaders over governmental authority.

5. Every new standfast meant in effect the withdrawal for an indefinite period of land needed by the plantations. 
6. The confidence of the entrepreneurs would be seriously shaken. The tobacco companies of East Sumatra had already been seriously hurt and yet another standfast would be very detrimental to the entrepreneurs' trust in legal protection by the government for their estates in Indonesia. ${ }^{22}$

This strong letter received wide distribution in both Medan and Jakarta, while a number of high officials, including Resident Djalaluddin, and delegations of peasant leaders lobbied in Jakarta, as did AVROS.

A visit by Minister of Agrarian Affairs, Professor Suhardi, a member of the Catholic Party, to Medan and tobacco estates July 20-22 for consultation with representatives of the tobacco industry and with Resident Djalaluddin gave the planters a valuable opportunity to stress the seriousness of the situation. Suhardi, though refusing to make a promise, assured the planters that he would do what he could, hinting that there would be no new standfast. At a 23 July meeting of the AVROS board of directors, Nolen reported a catastrophic new development on the tobacco estates. Whereas in the past there seemed to have existed a kind of coordination between BTI and the Communist labor union SOBSI, which had led the BTI to avoid squatting on land already prepared for the next tobacco crop, now for the first time squatters had planted rice stealthily at night in 360 hectares of United Deli Company fields which had been cleared, plowed, and harrowed for December 1956 and January 1957 tobacco plantings. This represented a loss to the tobacco company of an estimated Rp. 24.5 million. $^{23}$

During his discussions with the planters in Medan on 21 July, Minister Suhardi had asked Nolen for additional data, which were duly submitted in a letter ${ }^{24}$ tracing the postwar history of the tobacco industry and calling special attention to the following: 1. Since illegal squatting was scattered over an estate, a considerable percentage of the remaining land could not be used because the fields were either too small or too isolated for tobacco cultivation.

2. Squatters had in many places disturbed drainage systems to such an extent as to leave large areas without the drainage required for plantation crops and thus useless to the estates.

3. The remaining tobacco soils were becoming useless from the spread of plant diseases and pests as well as above-average growth of weeds spreading from nearby squatter holdings.

An estimated 50,000 hectares of the best tobacco soils had thus one way or another been made uncultivable by squatters, 
leaving only 65,000 - an area too small to sustain the Deli tobacco industry on the prewar scale, especially in view of the fact that these 65,000 hectares included the so-called tara lands plus land not suited for the growing of high-quality wrapper tobacco. Nolen illustrated the hopeless situation on five estates by giving the total area, the squatted area, the tara-land area, and the remainder available for use by the companies (see Table 12). All five faced closing unless the new squatters since 12 June 1954 were quickly removed. Medan Estate, Deli Tuwa, and Mariëndal had already been forced to stop operations because squatters on Tuntungan Estate had made it impossible for the United Deli Company to raise the tobacco seedlings normally grown there for the three other plantations.

Table 12

Squatter situation on three estates of the United Deli Company and two estates of the Senembah Company (in hectares)

\begin{tabular}{|c|c|c|c|c|c|}
\hline Estate & $\begin{array}{l}\text { Total concession } \\
\text { area left after } \\
\text { partition of } 1951\end{array}$ & $\begin{array}{l}\text { Occupied by } \\
\text { squatters by } \\
12 \text { June } \\
1954\end{array}$ & $\begin{array}{l}\text { Occupied by } \\
\text { squatters by } \\
25 \text { July } \\
1956\end{array}$ & $\begin{array}{l}\text { Tara- } \\
\text { land }\end{array}$ & $\begin{array}{l}\text { Remain- } \\
\text { ing area }\end{array}$ \\
\hline $\begin{array}{l}\text { Rotterdam, } \\
\text { of U.D. Co. }\end{array}$ & 2,800 & 210 & 1,800 & 400 & 600 \\
\hline $\begin{array}{l}\text { Timbang } \\
\text { Langkat, } \\
\text { of U.D. Co. }\end{array}$ & 2,246 & 380 & 1,000 & 400 & 846 \\
\hline $\begin{array}{l}\text { Glugur, } \\
\text { of U.D. Co. }\end{array}$ & 1,672 & 800 & 1,500 & 100 & 72 \\
\hline $\begin{array}{l}\text { Kwala Namu, } \\
\text { of Senembah Co. }\end{array}$ & 4,870 & 2,454 & 3,800 & 800 & 270 \\
\hline $\begin{array}{l}\text { Pagar Marbau, } \\
\text { of Senembah Co. }\end{array}$ & 4,424 & 1,832 & 4,000 & 300 & 124 \\
\hline
\end{tabular}

Source: AVROS letter No. 953 of 1 August 1956.

Nolen concluded by stressing that recent developments in the squatter situation were daily intensifying the threat of total disruption of plantation operations: a steadily rising number of mass invasions of squatters organized outside the tobacco region; theft by squatters from estate warehouses of e rer larger quantities of building and roofing materials; illegal occupation of tobacco soils that would lead to a loss of millions and millions of rupiahs in foreign exchange. By mid-August, some two weeks 
after submission of the letter, the planters observed that police authorities had suddenly begun to drive incoming squatters off estate lands though, as if in accordance with a new standfast, leaving squatters of even a few weeks' standing undisturbed.

\section{Revision of Emergency Law No. 8/1954}

Months of prodding, lobbying, and a steady flow of memoranda, situation reports, and letters finally produced results. On 2 October the Minister of Agrarian Affairs issued Emergency Law No. 1/1956, the purpose being to revise and supplement Emergency Law No. 8/1954. The explanatory memorandum accompanying the law referred specifically to the tobacco industry of East Sumatra, noting that the shift since July in the pattern of illegal occupation from fallow land only to land especially suited for seed beds or land already prepared for the tobacco crop of 1957 posed a real threat to the continued operation of the plantations and, since estate closings would deal a death blow to a significant source of the national income, had to be met by an immediate strengthening of the old law.

This took the form of increases in the maximum jail term from three months to six months and in the maximum fine from Rp. 500 to Rp. 5,000 and, even more indicative, of an extension of culpability to anyone who, directly or indirectly, orally or in writing, incited others to enter estate lands without permission of the management, to anyone who organized an illegal occupation, and, finally, to anyone who took over or purchased illegally occupied land. The new Emergency Law No. 1/1956 also called for evacuation within two weeks of any person found guilty of illegal occupation of land irrespective of a pending appeal versus the earlier law's provision for evacuation after a sentence had been confirmed by the court of appeal.

One of the first reactions in East Sumatra came from Resident Djalaluddin, who was quoted as favoring an agrarian law passed by parliament instead of an emergency law issued by a group of ministers who feared that they would not be able to win parliamentary approval of their ideas. Other East Sumatra officials were very slow in their response to the new law. As late as the end of October the police authorities of the kabupaten DeliSerdang in the heart of the tobacco belt had not yet received instructions for the implementation of the revised emergency law and still no invitations were forthcoming for a conference Acting Governor Sutan Kumala Pontas reportedly intended to hold with 
representatives of the various peasant organizations prior to the implementation. ${ }^{25}$

Three weeks later, on 21 November 1956, BTI, Petani, RTI, STII, Sakti, Gaperta, BPRP, and BP4R deluged the President, members of the cabinet, and members of parliament with telegrams protesting Emergency Law No. 1/1956 and demanding its repeal. ${ }^{26}$ Concurrent with the protest campaign, however, the rate of new invasions of estates by squatters declined markedly - a fact perhaps attributable to the stiffening of the law but just as likely to the season, November and December being normally rather quiet months on the agrarian front. Certainly the planters saw little evidence of official action leading to a large-scale transfer of squatters who had violated the law since June 1954.

The Negotiations of the United Deli Company with the Barisan Tani Indonesia

At the end of October 1956 an unexpected crisis arose in the ranks of the planters. Nolen and his staff in AVROS learned to their utter consternation that the directors of the leading tobacco company, the United Deli Company, had been secretly negotiating since September with the archenemy of the East Sumatran planters, the BTI. What shocked the directors of AVROS and the planter community as a whole was not only that the United Deli Company had acted contrary to the official policy of AVROS against private negotiations, a policy its representatives in the executive committee and on the board of directors had helped to formulate and had backed by their votes, but that it had done so without informing AVROS of its decision. This development presented AVROS with a dilemma: either reaffirm its policy and persuade the United Deli Company to break off its negotiations with BTI or revise its policy and leave agrarian settlements up to each member. Defending the decision to break the planters' solid front, a representative of the United Deli Company told the AVROS board of directors at a meeting on 20 November 1956:

"Desperate needs lead to desperate deeds. It may seem to you that the deed of the United Deli Company is indeed desperate. At this moment it is a question of life or death for the tobacco industry.

Above all as a result of the mass occupations since the beginning of this year the situation has deteriorated at an alarming rate on several of our estates. Unless the next month brings a solu- 
tion, we will be forced to close one estate in part and others will follow during the next year.

Furthermore, we are confronted by the problem that for six of our seventeen tobacco estates the seedlings are being raised on the so-called black soils of estates no longer in operation. These estates are for all practical purposes completely taken over by squatters, including the soils especially suited for the raising of seedlings. Unless a solution is found soon, another six estates will have to be closed.

On the occasion of the visit to Medan by the agrarian commission of parliament last September there developed by accident a contact with the BTI, which made it apparent that the BTI leaders were prepared to discuss matters. This has taken place, always in the presence of a government official. Naturally we did not know at the beginning whether there would be any real basis for successful negotiations with the BTI. Then came completely unexpectedly Emergency Law No. 1/1956, which was received by us on 11 October 1956. I agree with you that certainly it would have been better had we notified the board of directors after the first exploratory discussions. Unfortunately we failed to do so, and for that I tender my apologies. In the meantime we have already apologized to the Senembah Company, which is the most interested party. I do hope that this company may profit from our experiences, whatever the outcome may be.

All our experiences with existing occupation, where squatters had gained a foothold, have always been that not one squatter was expelled. We expect little from the actions of the authorities even after the proclamation of the new emergency law.

We are trying to achieve with the help of the BTI that almost all land occupied since 12 June 1954 be vacated. Locally areas will be rounded off. Every estate must retain an area large enough to allow profitable conduct of estate operations. New cases of squatting may not occur. I sincerely hope that the future will show that the road we have taken was the right one. The next few months will show this. We were desperate and something had to be done."27

Nolen, who had put so much emphasis on the importance of a collective front by the planters, countered with the following arguments:

1. A possible agreement with the BTI would constitute a confirmation of the government's impotence and a recognition of the BTI as the power on agrarian issues. 
2. The BTI will use a possible agreement as a propaganda tool. The propaganda will be directed against the government and against the other peasant groups. Furthermore, the BTI will make use of this opportunity once and for all to make impossible a firm action for the protection of estate grounds on the part of the government. The aims of the BTI should be a warning for us. 3. We recognize a legal difference between occupants of before and after the proclamation of Emergency Law No. 8/1954. If occupants who came after 12 June 1954 are brought into the discussion, we see no reason why we could not be forced to accept future occupants as our counterpart in a negotiation. (Yesterday's occupants do not possess more rights than those of tomorrow!)

4. Other tani groups - and especially the independent rakyat penunggu - will react very strongly if the BTI interests are secured. It will be possible to drag the Petani along, but not the STII and the BPRP. In short: it will not be possible to avoid political difficulties.

5. The partial absorption of new squatters and the ejection of others by means of consultation will bring up the problem of compensation.

6. This arrangement, which is perhaps possible for the United Deli Company, will not offer a solution for other companies. It will appear to be practically impossible to get rid of squatters without a local land offer. Other companies are already being told that it will not do to demand the vacating of occupied land without prior effort to reach a settlement with the illegal squatters.

7. The entrepreneurs and especially AVROS, which acted at the request and in the name of all the tobacco companies, will be seriously reproached that they until now made unreasonable demands. In this connection I wish to recall the position of Vorstman and the undersigned in the state commission $(1953 / 54)$ as well as the recent remonstrations in the course of 1956 in connection with the serious increase of occupations and the resulting shortage of tobacco soils.

8. Agreements of the type which the United Deli Company hopes to reach have been made in the past several times (but with old squatters). Only the entrepreneurs were always deceived. The occupied land was definitely lost and it led in fact only to greater loss of land. Those who in addition made financial sacrifices or provided technical assistance for the construction of roads or the clearing of land have done so always in vain. 
9. The intended agreement is, in my opinion, a poor revival which has taken place in the tobacco region and which did not go hand in hand with satisfactory guaranties for the remainder of the tobacco area.

10. Now that the United Deli Company has entered into negotiations with the BTI, the government officials have an excellent reason not to implement the government's intention to clear up illegal occupation. Other companies learn to their sorrow that local officials refer to these negotiations. It must be feared that the BTI's only aim is to prevent the implementation of Emergency Law No. 1/1956. In any event, it must be noted that nothing happens in East Sumatra, while results have been achieved in Java.

11. Should it be possible to reach an agreement with the BTI, it will mean that Deli tobacco will stand or fall with the BTI or possibly with a certain leader of the BTI (S.M. Tarigan).

In conclusion I have objections which are derived from my suspicion that the United Deli Company has become the victim of a political gamble on the part of certain persons who until now never showed any interest in the welfare of plantation agriculture in East Sumatra. ${ }^{28}$

It soon became clear no such arguments were going to deter the United Deli Company, which categorically rejected a suggestion that its negotiations with the BTI be guided to a deadlock. Nor was the majority of the AVROS board of directors willing to consider any change in its policy of controlling the actions of its members, as it would be in conflict with the interests of its membership as a whole to leave agrarian settlements up to the individual companies. Obviously, if the unity of action by all members was to be preserved, AVROS had either to enforce compliance to its policy by the United Deli Company or to expel the rebellious company from membership. After prolonged discussion it was decided to table the issue until members had had time to consult their respective headquarters in The Netherlands.

It so happened that this critical problem arose just as President Nolen left AVROS, his successor J. Fernhout taking office 23 November 1956. Fernhout, at a directors' meeting on 20 November, announced that he would be unable to lead an organization whose members were not prepared unanimously to pursue a policy approved by its board of directors. Then at the 4 December meeting Fernhout told the members of a suggestion made to the United Deli Company in an executive committee 
session that its representatives approach their BTI counterparts about the transfer of their agreements, now including mutual recognition of interests and possible solutions, to appropriate government authorities for final negotiation and implementation. Though still unwilling to break off its negotiations, the United Deli Company had seemed inclined to bend the negotiations in the direction of a consultation led and approved by the authorities. Thus the first steps had been taken toward a compromise that would place the negotiations at least under the authority of the government.

At the same meeting the United Deli Company representative announced an extension of the negotiations, through the good offices of the Resident, to the other peasant organizations. The BTI knew of this widening of the negotiations, which had been the intention from the start. In Medan as well as Jakarta, the United Deli Company representative observed, the trend of the negotiations had been steadily shifting toward the government. For example, the United Deli Company had presented in Jakarta at the request of the Minister of Agrarian Affairs an elaborate budget for an irrigation project, and learned that the government might be prepared to finance such a project in its entirety, without contributions from the entrepreneurs - certainly an opportunity for AVROS as an organization to take matters in hand. Discussion of the possibility was ruled out of order by the chairman on the grounds that the position of the United Deli Company remained basically the same and that the meeting had been called primarily to hear the views of the various headquarters. Furthermore, although several members of the board had heard from their directorates in The Netherlands, ongoing consultations in The Netherlands relative to the United Deli Company made tabling of the question advisable until the next meeting at the end of December. Meanwhile the representative of the Netherlands Trading Company (NHM) asked permission to read a statement from his directors in Jakarta which gave qualified support to the position of the United Deli Company. The NHM directors, although regretting the break in AVROS solidarity, could well understand why the United Deli Company, in serious difficulties because of the growing squatter problem and with no government solution in sight, had decided to act independently if necessary to protect its interests. Whether the United Deli Company had chosen the right way only the future could show, but the NHM directors felt strongly that the very drastic measure of expelling the company from AVROS would be both premature 
and unjustifiable, that beside the agrarian issues AVROS had sufficient opportunities for fruitful cooperation. The NHM statement drew from the AVROS chairman the comment that the board wanted to wait for the views of the managing boards in The Netherlands and had not so much wanted to hear the opinion of directorates with seats in Indonesia. As for the place of agrarian policy in an organization of planters, the agrarian sector was probably the last one such an organization as AVROS could afford to leave to the individual discretion of its members. ${ }^{29}$

The following compromise is recorded in the minutes of 29 December:

"In the future the United Deli Company will not make any decision or take any steps in matters of importance reserved for AVROS action by the AVROS board of directors without first discussing the issue in the AVROS board of directors in order to receive the latter's approval. The United Deli Company reserves the right to choose its own course of action, should it be impossible to reach an agreement between the company's views and those of the other members of the board of directors. In the latter case the company is prepared to accept the consequences." 30

This rather weak compromise seems to indicate that several directorates in The Netherlands shared the views expressed by the NHM at the meeting of 4 December. The chairman made the face-saving remark that naturally every member company in principle reserved the right to choose its own course of action should it reach the conclusion that it definitely could not accept the viewpoint of the majority and was prepared to accept the consequences. But the whole affair had definitely weakened the position of AVROS in its negotiations with the government. The apparent willingness of the United Deli Company to go beyond the 1951 agreements and voluntarily agree to a further drastic reduction of its estates area exposed the other companies to the suspicion that they too had been overstating their cases and that therefore the pressure should be maintained. It was ironic that just at the moment when the government finally responded to many months of prodding and lobbying and met the demands for firm action, the oldest and leading company of East Sumatra had entered into negotiations with the spokesman of the Communistaffiliated peasant organization. This certainly reduced the willing- 
ness on the part of provincial officials to enforce a most unpopular law. It was only too convenient for them to sit back and to await the outcome of the United Deli Company - BTI discussions.

Although the United Deli Company and BTI had agreed on the draft of their joint agreement by 1 November 1956, the agreement was not signed until 14 January 1957 by D. van Eck and Chief Administrator G. den Broeder on behalf of the United Deli Company and by Secretary General S.M. Tarigan on behalf of the Board of Directors of the BTI for North Sumatra. The document was witnessed by Governor Sutan Kumala Pontas. Its chief provisions stipulated that:

The BTI expected that the largest village communities should become centers around which the widely scattered squatters would concentrate for the development of an efficient, intensive, and well-organized peasant agriculture; that for each district joint consultation should determine:

1. in how far assistance should be rendered for the preparation of the land offered in exchange;

2. the rate of compensation for houses, huts, and crops that had to be moved or left behind;

3. assistance with surveys and staking out of irrigation systems; 4. assistance with transportation of squatters who had to be resettled; and

5. additional assistance, such as the provision of technical guidance in the field of agriculture through the development of an experiment station - two hectares in size - in which crops of interest to smallholders were to be grown.

In return for these BTI demands, the United Deli Company stipulated that:

1. the company would keep at its disposal areas which were to be as compact as possible;

2. the BTI accept the boundaries of the estate area as established by the joint agreement with the understanding that there should not be any squatted areas within the boundaries of the estates; the remaining estate area should be regarded as the minimum for an economical conduct of business and that therefore no additional land could be released;

3. the company should have complete access to, control over, and maintenance of roads within the estates; 
4. the company should have complete access to, control over and maintenance of watercourses that served the tobacco cultivation;

5. the company should have ownership of all houses, sheds, etc. within the estate areas as they were being established district by district; and

6. the target date for the evacuation of the squatters be set for 31 December 1956.

The joint agreement established nine districts, encompassing the following estates:

District 1: Rotterdam, Timbang Langkat, and Sungai Mencirim

District 2: Bandar Chalipah, Amplas, Mariëndal, and Deli Tua

District 3: Medan, Sampali, Saentis, and Mabar

District 4: Helvetia, Klambir Lima, and Klumpang

District 5: Tandem, Tandem Hilir, and Bulu Cina

District 6: Kwala Begumit and Kwala Bingei

District 7: Padang Brahrang and Tanjong Jati

District 8: Kwala Mencirim and Binjai

District 9: Glugur and Tuntungan

Even after four months of negotiations so much was left to subsequent implementation and interpretation that there was ample opportunity for disagreements, as the months to come would show.

In view of the well-established Indonesian pattern of the inability of central authorities to enforce their commitments and laws and the unwillingness of lower echelons of the bureaucracy to accept and to implement unpopular laws, the question arises why the directors of the United Deli Company were so optimistic as to expect that Tarigan and the board of directors of the BTI for North Sumatra would be able to enforce the agreement. This implied a willingness of every local branch of the BTI to accept the terms of an agreement calling for an uprooting of many squatters and a ban on illegal occupations in the future - when the BTI had for years ignored such bans issued by the government. Apparently the United Deli Company and the BTI leaders decided to enter into direct negotiations because they were dissatisfied with the lack of initiative on the part of the KRPT, which had been given the assignment of bringing the opposing parties together to settle the outstanding issues estate by estate.

The agreement arrived at without the intermediacy of the 
KRPT incorporated many provisions of the Joint Decree of 30 June 1955 which the BTI had welcomed but the United Deli Company had opposed bitterly. The agreement thus represented an about-face for the United Deli Company, a victory for Tarigan and his BTI followers, and a setback for the KRPT.

As pointed out above, the Medan press and the provincial officials had been critical of the creation of the KRPT and the appointment of a Javanese to an office which required thorough familiarity with East Sumatra. It is therefore not surprising that the KRPT was carefully watched and constantly criticized. Instructions issued by Minister Gunawan had sanctioned the delay in actual resettlement of any families until after the December 1955 elections to prevent their loss of voting rights, but when in mid-January complaints began to reach Jakarta about the inaction of the KRPT, Imam Supangat was called to the ministry to give an explanation. His unsatisfactory answers brought his transfer back to Java and the appointment of Tengku Kotjik as head of the KRPT. Kotjik, born in East Sumatra, at least met the local demands on that score. But the provincial officials also objected to the administrative change made by Singgih that put the KRPT under the direct control of the Ministry of Agrarian Affairs rather than under the governor as its predecessor, the KPPT, had been. This resentment probably explains why Resident Djalaluddin's Badan Pembantu staffed entirely by provincial officials, which was to assist to KRPT, remained quiescent, apparently failing to meet even once during 1956.

Another of the numerous difficulties that beset the KRPT was the bureaucratic struggle over funds absolutely critical for the forceful conduct of a resettlement program. By mid-year, Kotjik had succeeded in resettling some 500 squatter families from the HVA estates of Balimbingan and Laras in the kabupaten Simelungun. These squatters gladly accepted the KRPT's resettlement proposal since their land was exhausted, so that they needed new land. Because of the KRPT's failure to support the squatters in accordance with the provisions of the Joint Decree, the latter threatened to reinvade HVA estate lands. ${ }^{31}$

The steady sniping at Kotjik from the side of the BTI and Petani and their affiliated newspapers resulted in his removal from office in November despite the support which he received from such quarters as Masyumi, NU, PRN, STII, and BPRP. The negotiations between the United Deli Company and BTI without the sponsorship of the KRPT contributed to the dismissal of the second head of the KRPT. 
Collapse of the Agreement between the Barisan Tani Indonesia and the United Deli Company

The BTI - United Deli Company agreement reached on 14 January 1957 after months of negotiations apparently foundered when the company proved unable to win similar agreements from the other peasant organizations. Representatives of the company claimed both in December 1956 and again in February 1957 that negotiations were proceeding to their satisfaction, but on 6 March eight peasant organizations issued a joint declaration condemning the BTI - United Deli Company agreement on the grounds that it called for direct transfer of land exclusively to the members of one organization. ${ }^{32}$ By June five of the eight had reversed their position and, joining with the BTI to form the United Front of Peasant Organizations of North Sumatra, or Kesatuan Aksi Organisasi Tani-Tani Sumatra Utara, signed an agreement with the United Deli Company. ${ }^{33}$

From all evidence the United Deli Company derived very little from the agreement - at the most the resettlement of a few squatters. Scrutiny of the Medan press during this period reveals no notable resettlement and, in fact, several new cases of illegal occupation by groups of squatters belonging to the BTI. ${ }^{34}$ The same picture emerges from the monthly AVROS statistics on the number of hectares of estate land occupied by squatters between January and October 1957. Nor do the minutes of the monthly meetings of the AVROS board of directors refer to changes on the tobacco estates of Langkat and Deli-Serdang, except to speak of a "fiasco". Apparently a major reason why the agreement never reached a significant level of implementation was the central government's decision not to finance the development of large-scale irrigation projects for the benefit of resettled squatters, and the United Deli Company, true to its long-standing policy, was not willing itself to underwrite the expenses. By late October the company was trying to arrange the evacuation of squatters from land to be used for the cultivation of tobacco by 1959 despite its full awareness of the difficulty for psychological reasons of clearing squatters from land that would then have to be left fallow for several years. 
CHAPTER VII

\section{THE NATIONALIZATION OF DUTCH PLANTATIONS}

\section{The Agrarian Issues and the Military}

The declaration of martial law in North Sumatra on 24 December 1956 had important consequences in that it involved the military authorities as a new party in the agrarian dispute. The immediate reason for the declaration of martial law was the short-lived coup of Colonel Simbolon, commanding officer of the First Military District, who on 22 December 1956 severed relations between the province of North Sumatra and the Ali Sastroamidjojo Cabinet. Simbolon's coup failed because he underestimated the ethnic complexity of East Sumatra and the great rivalry between the population groups. The striking postwar ascent of the Toba Batak from Tapanuli in the affairs of East Sumatra was resented by the native Malays and the Karo- and Simelungun-Batak as well as the Javanese both within and outside the plantations. Lieutenant Colonel Djamin Gintings, Simbolon's chief of staff, a Karo, Lieutenant Colonel Sugi Arto, the commanding officer of the Medan garrison, a Javanese, and Lieutenant Colonel Wahab Makmur, an Acehnese, all shared resentment of Toba Batak power in East Sumatra. All three turned against Colonel Simbolon and forced him to retreat with his Toba Batak followers to their homeland in Tapanuli. Under martial law the territorial army commander, his staff, and subordinate regimental battalion and company commanders exercised powers normally held by their counterparts in the pamong praja corps of civilian administrators. ${ }^{1}$ Among the issues with which the military became concerned was the squatter problem, so that in 1957 AVROS had to deal with the military as well as the provincial and central government authorities.

The first indication that the military authorities were concerning themselves with the agrarian problem came on 24 December 1956 when the commanding officer of the Medan garrison issued a standfast order against illegal occupation of land within the 
boundaries of the city of Medan, which included parts of tobacco estates bordering on Medan. This was followed on 1 January $1957^{2}$ by an announcement issued by Major Zain Hamid, commanding officer of Battalion No. 133, as military administrator for the kabupaten Deli-Serdang, to the effect that as of 1 January new squatting violations would be handled by the military police, with earlier violations to remain the responsibility of civilian authorities. On 10 January 1957 the press officer of the first Military Territory confirmed that the military police (C.P.M., or Corps Polisi Militer) had received instructions to take firm measures against squatters. Then in January 1957 Lt. Col. D. Gintings issued a decree ${ }^{3}$ revoking both military standfast orders.

These events transpired without public explanation - indeed without publicity. AVROS did not learn of the military standfast order for the kabupaten Deli-Serdang until some two weeks after its revocation, and the revocation order did not come to the attention of AVROS until March. ${ }^{4}$ It was also in March that AVROS first heard of a plan by Gintings to issue regulations concerning illegal occupation of estate land when his special secretariat for the enforcement of martial law requested copies of all letters and memoranda about agrarian conflicts for its information. ${ }^{5}$

There was a noticeable increase during April in squatter activities, i.e. in the illegal construction of semipermanent houses in Deli and of unauthorized irrigation canals in Simelungun as well as in more widespread occupation of land. Some of this new activity was attributable to organized veterans groups, which went unchallenged by the police authorities with the explanation that soldiers and veterans came under the jurisdiction and supervision of the military police. The latter remained inactive.

In mid-June 1957 AVROS unofficially obtained a copy of a decree signed on $10 \mathrm{May}^{6}$ - but not yet released - by Gintings as Regional Military Administrator (Penguasa Militer) for North Sumatra, in which Gintings reconfirmed Emergency Laws No. 8/1954 and No. 1/1956 and emphasized the military's determination to bring the agrarian situation under control through their enforcement. ${ }^{7}$ What disturbed AVROS about this otherwise - from its point of view - commendable decree was an article which permitted negotiations in cases of illegal occupation after 12 June 1954, clearly in contradiction to Emergency Law No. 1/1956 and, in effect, a post factum legalization of unlawful acts. It became apparent that civil authorities, notably the governor, and KRPT, objected to military interference in agrarian matters. 
So too of course did AVROS, which would have preferred a limitation on the military, e.g. to assisting civilian authorities evict convicted squatters. As was to be expected, the militant peasant unions protested against the proposed decree as much as they had protested against the original emergency laws. Possibly because of the objections raised in various quarters against the decree of 10 May 1957, it was never formally promulgated, although several Medan newspapers referred to it indirectly as late as the end of June. ${ }^{8}$ Quite obviously Gintings and his staff found the agrarian issue as difficult as had previously the civilian authorities, the police, and the prosecutors and judges - thus the lack of a clear line and the reticence to act, particularly in instances involving organized veterans. On 16 July Gintings appointed an agrarian commission for the first Military Territory and requested its recommendations within two weeks. The composition of this commission is significant: the chairman and secretary were army officers; the first vice-chairman, the second vice-chairman, and four other members were high civil government officials; and the remaining two members were from leftwing peasant organizations. There were no planters. The two representatives of peasant organizations, S.M. Tarigan and Asjro Effendy, who had represented the Sekretariat Bersama in the state commission in 1954, were not identified in the new commission as such, being listed instead respectively as civilian advisor to the Secretariat for the Administration of Martial Law and member of the Provincial Council of Representatives for North Sumatra (Effendy represented Petani). The inclusion of these two old opponents was a matter of considerable concern for AVROS, as was the absence of any representative from the Service for Estate Agriculture.

Given only four days to prepare a statement on current difficulties with illegal squatters, AVROS nevertheless on 26 July submitted its comments and recommendations to the new agrarian commission. It pointed out that the planters were really the "third party" in a conflict between squatters and government arising out of violations of the law, but it submitted statistics detailing the extent of standfast violations after 12 June 1954, 24 December 1956, and 30 June 1957 for each of the kabupaten of East Sumatra. It stressed that the consequences of illegal occupation were even greater than the statistics indicated in that widely scattered patches of squatted land made intervening land unusable for the tobacco industry. It also noted that, because the courts handled only a small portion of all the reported violations 
of the standfast, most of the squatters were gaining a firm foothold on the land by building permanent structures and planting trees. Even the declaration of martial law had not prevented the loss of another 4,800 hectares of estate land under the very eyes of the Regional Military Administrator between 1 January and 30 June 1957. Uncontrolled illegal occupation of tobacco land would eventually mean the closing of estates and the concomitant unemployment of many more people than could support themselves on the same area as subsistence farmers. As for recommendations, the planters continued to advocate the full development of the agricultural potential of uncultivated portions of the public domain and of the land returned by the tobacco estates. This should include above all the development of irrigation projects in the tens of thousands of hectares of land in East Sumatra that could be turned into excellent wet-rice fields though, the letter concluded, it made little sense to search for a solution of the agrarian problem without simultaneously bringing new squatting to a halt. ${ }^{9}$

By early September Lt. Col. Gintings, as Regional Military Administrator, had a set of recommendations by his agrarian commission ready to submit to Jakarta and so sent several commission members (including Tarigan of the BTI and Ali Wasitohardjo of the KRPT) to the Army Chief of Staff, the Central Military Administrator, to ask for his approval. The commission recommended a coordinated regional planning and reconstruction program for North Sumatra as a whole. But first the flow of Batak squatters from Tapanuli into East Sumatra must be stopped. Among the suggested measures for accomplishing this was the opening of new settlement areas in Tapanuli and other parts of North Sumatra outside the plantation belt to divert potential migrant-squatters, the closing by the military of certain districts of East Sumatra (especially the kabupaten of Langkat and Deli-Serdang), and stricter regulation of exit papers issuance by the Tapanuli civil authorities. It was further suggested that squatters from before the 12 June 1954 standfast be given two hectares per family, preferably at their present abode, and that a new standfast be decreed as of 7 May 1957 to provide at least temporary protection for all squatters who had arrived after the old standfast.

At an interdepartmental conference held at the headquarters of the Army Chief of Staff on 11 September 1957, the Minister of Agrarian Affairs expressed objections to several points, especially the request for a new standfast, but realized the political neces- 
sity of balancing his opposition to the plan with constructive counterproposals worked out in cooperation with AVROS and the plantation companies. Rozendaal, the Jakarta representative of AVROS, rushed a letter to the board of directors explaining the urgency of the situation and why therefore Minister Sunarjo needed as soon as possible the maps showing the 180,000 hectares the perennial-crop estates were to release so as to support his counterproposal that temporary long leases be issued at once for the estates' remaining land. An early arrival of AVROS President Fernhout was important but, Rozendaal warned, Fernhout must come prepared to give Minister Sunarjo a binding answer, as any further temporizing would not work. ${ }^{10}$

In the same letter Rozendaal reported a new break in the planters' organizational solidarity, namely, a round of talks between Van der Made, representative of HVA, and the Minister of Agrarian Affairs. In reply to the question why HVA had not first informed the AVROS board of directors in which it held a seat, Van der Made told Rozendaal that the concept of an integral handling of the agrarian problem was an anachronism and that each company had to find its own solution. The similarity of the HVA position and the position taken by the United Deli Company in 1965 seems to have been more than a coincidence, for Van Eck of the United Deli Company was in Jakarta at the same time and met with the HVA representative frequently. It turned out that Van der Made had agreed to present to the Ministry of Agrarian Affairs the HVA maps which showed the land to be returned to the government.

Fernhout opened a hurriedly called meeting of the board of directors 11 September with a report on the HVA talks and a request that the board settle once and for all the question of whether the handling of the agrarian problem should in the future remain a task for AVROS or whether it should be left to each individual company. It was a matter of putting the AVROS president in the impossible position, during negotiations with the government, of having to speak in the name of some AVROS members but not in the name of others - should the directors allow exceptions to their policy. With expressions of regret over the new break in AVROS' united front, the board reaffirmed the policy of collective negotiation on the agrarian issue.

Mollified by this response, Fernhout proceeded to outline the East Sumatran agrarian commission proposals then before the Central Military Administrator for approval. Rozendaal had already made AVROS' objections on some points known in the 
Ministries of Agriculture, Agrarian Affairs, and Finance, and reported opposition in the Ministries of Defense, Agriculture, and Agrarian Affairs to a new standfast for East Sumatra. This latter was in keeping with a recent conversation with the Governor of North Sumatra, who had admitted that it was impossible, however great his own wish to do so, to enforce the law against squatting for the simple reason that effective enforcement depended on the backing of Jakarta and such backing could precipitate another cabinet crisis.

As to Minister Sunarjo's request for the maps in exchange for his promise of action on the issuance of temporary leases valid until a new basic agrarian law could be enacted, Fernhout considered the offer both honest and acceptable. Not only would the planters gain a measure of security for future operations but the government, which in his opinion needed actual control over projected resettlement areas before any really effective removal of squatters could take place, would have a new basis for action. Eliminated at the same time would be the two main reasons for AVROS' refusal to submit these maps in the past, i.e. the unspecified character of the new rights and the fear that a general knowledge of the location of the land to be released by the estates would lead to a new rush of squatters and to land speculation. In a prolonged discussion of the matter, one director reminded the gathering of the tobacco planters' similar situation in 1951, where agreement to a land partition had led to their loss of control over 145,000 hectares and a higher number of squatters than before. Another director expressed concern that the alternative to release of 180,000 hectares now was the unacceptable set of recommendations made by the agrarian commission.

Concluding the discussion, Fernhout summarized the arguments for cooperation with Minister Sunarjo as:

1. Land would be made available for the resettlement of squatters interfering with estate operations.

2. The planters would receive agrarian rights better than those in the old agricultural concession contracts, at the same time greatly improving the legal position of estates with expired contracts.

3. The objectionable recommendations of the agrarian commission could be cut out once the Minister of Agrarian Affairs was in the position of making counterproposals.

The board of directors agreed but insisted on the following set of conditions in exchange for delivery of the maps: 
1. Long leases would be issued for the approved target areas ${ }^{\mathbf{1 1}}$ : thirty-year leases for tobacco plantations and forty-year leases for perennial-crop plantations, including sisal plantations, with such leases to be replaced as soon as the new agrarian law had been promulgated.

2. The government would guarantee access roads to the plantations and control over the water regime of their target areas.

3. In principle, it would be the aim to resettle all squatters located within the approved target areas.

4. Plantation laborers occupying land illegally would have to decide whether in future they wanted to be laborers or farmers, with those choosing to be laborers made to give up the squatted land and be satisfied with the small garden plot every laborer is given in accordance with the labor law. ${ }^{12}$

Fernhout received the mandate to negotiate with Jakarta authorities and to offer the requested maps and the land in exchange for written confirmation of this set of four conditions. ${ }^{13}$

The same day the directors of AVROS were authorizing Fernhout to accept the proposals of the Minister of Agrarian Affairs an interdepartmental meeting of high officials was taking place in the headquarters of the Army Chief of Staff, who after examination of the East Sumatran plan prepared these recommendations for the Central Military Administrator. ${ }^{14}$

\section{A. Sector Development}

1. In principle we agree with the idea of planning an integral and coordinated development program of regions with the help of special funds, over and above the regular budget of the various departments to be involved.

2. The execution of the planning should be the responsibility of a special committee operating under the leadership of the Regional Military Administrator or his deputy as chairman, with its members to be drawn from:

a. the pamong praja corps, i.e. the group of territorial administrators, and such technical services as the Services for Plantation Agriculture, for Peasant Agriculture, the Forest Service, the Bureau for Land Planning, the Service for Transmigration, and the Service for Agrarian and Cadastral Affairs;

b. peasant organizations and the Government Estates Administration, the latter representing plantation agriculture.

B. Sector Legal Instructions

1. In order to reduce the number of those who have to be 
indicted because of illegal occupations, the government should establish the boundaries of the plantation area in such a manner that as many of those who squatted on land before 12 June 1954 may keep their holdings without undue interference with the economic operations of the plantations.

2. Land illegally occupied by members of government organizations (armed forces, police, and other government officials) must immediately be vacated.

3. Territorial officials (pamong praja) in the districts adjacent to the plantation belt should as much as possible reduce the issuance of exit-papers to the populace intending to migrate.

4. Plantation areas which are to remain under the control of the planters should be declared military, i.e. closed, territory.

C. Appointment of an Interdepartmental Technical Commission An interdepartmental, technical commission should be dispatched to East Sumatra as soon as possible for the gathering of concrete data both on specific projects and their costs, so that central and provincial officials can reach agreements on development projects.

These two meetings of 11 September prepared the ground for discussions held in Jakarta between delegates of AVROS and the Ministers of Agriculture and Agrarian Affairs on 18 and 19 September. ${ }^{15}$ In the 18 September meeting the Minister of Agrarian Affairs formally outlined his reasons for calling for maps showing the target area for each plantation of East Sumatra and explained how, upon their approval by the proper authorities of the central government, these target areas would be declared military zones and thereafter protected from illegal trespass. In addition, illegal occupants within an approved target area would be resettled, though the Minister hoped target areas would be selected in such a way as to keep the number of squatters to be resettled as small as feasible. Portions of agricultural concessions or long leases not part of target areas had to be returned to the government.

The planters then presented their four desiderata in the matter, all four of which the minister found acceptable. But, when asked for written confirmation of their acceptance, Sunarjo responded that such approval would have to come from the cabinet. The matter was resolved with an agreement that AVROS submit a formal document outlining their four points. As for delivery of the maps, which the planters insisted could not be prepared in less than a month, Sunarjo urged an earlier delivery with the counsel that it would be in the interest of the plantations to 
obtain the approval of their target areas from the Ministry of Agriculture as quickly as possible. Even the speediest implementation of the minister's plan, however, would be too late to forestall the closing of a certain few tobacco plantations or an end of the whole sisal industry, and for these emergency cases the planters suggested preferred handling under the plan coupled with special instructions to the military authorities to see that Jakarta's instructions for suppression of illegal occupation were actually carried out. Minister Sunarjo acknowledged the urgency of some planters' problems and promised his support of the proposed solution. Assuring Sunarjo of their full agreement with his plan, the planters then asked for further discussions following the cabinet's deliberations.

On 19 September the AVROS delegation met on the same matter with Minister of Agriculture Sadjarwo, who like Sunarjo found the four desiderata acceptable but who raised two additional questions. The first was whether the members of AVROS were willing to provide transportation for those squatters who had to move from the target areas. The planters "agreed to this with some reservation". As to the approval of the target areas - the second question which arose - the minister promised to instruct the head of the Estates Service (Jawatan Perkebunan) to establish a team of officials for this task.

In view of the great importance of the meeting with the Ministers of Agrarian Affairs and Agriculture, AVROS called a special general membership meeting for 27 September in order to give members an opportunity to voice their opinion of the agreements which had been reached in Jakarta and were now awaiting formal approval by the cabinet. Fernhout agreed with the board of directors that the proposals should be endorsed since under present circumstances no other solution was feasible, especially in view of the fact that the Ministry of Agrarian Affairs had had to drop its efforts to get the two emergency laws enacted by parliament as regular laws because of strong opposition. Apparently the members concurred, for the ensuing floor discussion produced no real dissent. The proposed designation of planted areas, land formerly planted but cleared during World War II, and tara lands as target areas with small parcels to round off estates was attractive for perennial-crop estates since a high percentage of these estates were no longer interested in large investments linked with substantial increases of the area under production. This definition of target areas posed problems for the tobacco estates of course, where the system of rotation required 
the disproportionately large fallow areas that to the uninformed gave the appearance of underutilization or outright neglect, but even so the agreements promised a long-awaited stabilization of the agrarian situation. The meeting of 27 September accepted the recommendation of the board of directors, and the members agreed to prepare the required maps speedily. ${ }^{16}$

Minister Sunarjo informed the Governor of Sumatra of the government plan worked out with the AVROS delegates and asked for his cooperation in letting AVROS know that maps showing size, location, and boundaries of their target areas were due in Jakarta by 2 November 1957. Sunarjo added that it would be in the interest of the entrepreneurs to draw the boundaries of their target areas in such a way as to avoid, as much as possible, the inclusion of squatters dating back prior to 12 June $1954 .{ }^{17}$

The next move was the appointment of an interdepartmental government technical committee consisting of ten members, with Singgih Praptodihardjo of the Ministry of Agrarian Affairs as chairman. ${ }^{18}$ This committee spent from 20 to 26 October in North Sumatra, including two days in Tapanuli, and on 22 October met with AVROS representatives. In the course of these discussions chairman Singgih requested a formal letter addressed to the Minister of Agrarian Affairs stating the AVROS desiderata connected with the selection of target areas and the concomitant return of the land outside the target areas, explaining that such a letter was needed before the government could give AVROS the requested written confirmation. It proved to be a welcome request because during the discussions several points had arisen which had not been taken into consideration in the talks held in Jakarta on 18 and 19 September. AVROS thus gained an opportunity for review and reformulation of their demands. One of these points related to squatters within the target area of an estate and Singgih accepted the idea that a circle drawn around the factory of an estate, with a radius to be determined, should be entirely cleared of squatters in order to provide the necessary security and freedom from interference for the factory complex.

Although the agrarian commission of the First Military Territory was still pressing for acceptance of its plans, Singgih assured the planters that the central government reserved the final settlement of the agrarian issues for itself but would have to take the local demands as much as feasible into consideration. Fernhout called Singgih's attention to the great difficulties which the sisal and tea estates of Simelungun experienced and expressed the hope that the committee would devote some time to the problem 
during their forthcoming visit to Simelungun and Tapanuli. Singgih promised to do so and also to discuss the matter with the governor before his departure for Jakarta on 26 October.

The AVROS board of directors meeting of 28 October was in the main devoted to a careful review of issues that had come up during the meeting with Singgih's committee and to the official letter requested by Singgih. In order to avoid the impression of a considerable increase in the number of their requests, the directors recommended a complete change of the draft and suggested the letter avoid the numbering of demands. ${ }^{19}$

Referring to the meeting of 18 September and the meeting with the interdepartmental technical committee of 22 October, Fernhout recalled that on both occasions the representatives of AVROS had declared the planters' readiness in principle to return land falling outside the target areas, provided that these target areas included all those lands considered absolutely necessary by the planters to an economically sound continuation of the estates and that the planters received in exchange long leases valid until comparable new rights could be enacted in a basic agrarian law. Fernhout then requested the further conditions that the conversion of the presently valid rights as a consequence of the target area procedure should include the planters' right to ask for a decisive answer fifteen years prior to the expiration of a $h a k$ usaha (right of exploitation) concerning the possible extension of this right; that the granting of new long-lease rights should not involve special financial consequences for the planters; that access roads to and control over drainage of the approved target areas should be guaranteed in accordance with Article 625 of the Indonesian Civil Code; that resettlement of all squatters within target areas should be effectively and promptly carried out; and that estate laborers holding land illegally should be made to choose between a future status of farmer or laborer and in the latter case made to give up all land but the estate laborer's customary vegetable garden. The letter closed with the hope that the Minister of Agrarian Affairs would obtain formal cabinet approval of the AVROS requests. A few days later, the AVROS delegate in Jakarta reported that in all probability requested written guarantees would be forthcoming.

\section{The West Irian Crisis and the Take-over of All Dutch Estates}

Yet the apparent progress of the Sumatran planters in their struggle to find a solution to the agrarian problem was soon 
brought to a halt as the West Irian issue once more began to becloud the political horizon. News of the decision in September by the Indonesian cabinet under Prime Minister Djuanda Kartawidjaja to present the West Irian issue for the fourth time to the General Assembly of the United Nations signaled a feverish campaign to arouse nationalistic fervor in support of the Indonesian demand for sovereignty over West Irian, the purpose being to draw the favorable attention of the outside world and especially the members of the General Assembly by mass demonstrations, resolutions, and threats of countermeasures if West Irian was not transferred. At the beginning of October the cabinet approved the holding of a "West Irian Week" and the formation of a "West Irian Action" committee, the latter to be composed of representatives of the Ministries of Information and Foreign Affairs, of the National Council, and of various mass organizations. At the end of October Information Minister Sudibjo formed the "West Irian Liberation Committee" to be headed by the minister himself.

Following the government lead, the Communist-dominated trade union federation SOBSI joined the nationalistic campaign by calling for firm political action to effect such goals as:

1. restrictions on the transfer of profits of Dutch enterprises abroad, withdrawal of the special rights of the Dutch oil company (BPM), and the take-over of all Dutch-owned banks;

2. the take-over of all shipping lines and shipyards so as to end the Dutch monopoly in interisland shipping;

3. the take-over of all Dutch-owned plantations as well as import and export houses; and

4. a break in diplomatic relations with The Netherlands. ${ }^{20}$

Practically every party or mass organization was caught up in the nationalistic fervor which rose to a climax in November as the UN vote approached. The Surabaya city council, for example, passed a resolution calling for a boycot of Dutch business houses and "slow-down" actions against Dutch enterprises. The West Irian Liberation Committee launched the "second wave" of the liberation drive on 10 November. D.S. Tarigan, Secretary General of the Veterans Legion, learned in Medan that the East Sumatran division of the Legion was urging immediate restriction of diplomatic relations between Indonesia and The Netherlands and complete severance of diplomatic ties should the vote on the West Irian issue be unfavorable. ${ }^{21}$ 
The socialist newspaper Pedoman quoted an unidentified official of the Ministry of Finance as predicting that Indonesia would break off her trade relations with The Netherlands and nationalize Dutch business, banks, and plantations should the peaceful efforts for solution of the West Irian issue prove ineffective. ${ }^{22}$ And on 7 November 1957 Sukarno warned that "if the United Nations fails us we will resort to methods that will startle the world". Again and again nationalists and leftists reminded the public that the Dutch enterprises in Indonesia provided The Netherlands with the funds necessary for its West Irian policy and that only a complete take-over of these enterprises would force the Dutch government to transfer sovereignty over West Irian to Indonesia. On 18 November 1957 Sukarno, Prime Minister Djuanda, and several ministers of the cabinet attended a "West Irian Liberation" mass rally at Banteng Square in Jakarta at which Sukarno repeated his warning that "if the United Nations should fail again to effect the restoration of West Irian to Indonesia, we shall press our claim to the Dutch in such a way that they will have to yield". ${ }^{23}$ A resolution adopted at the same rally called for such retaliatory steps in the event of an adverse UN vote as refusal to renew agricultural concessions and long leases, nationalization of Dutch-owned vital industries, repatriation of unemployed Dutch nationals "who are of no use to Indonesia's reconstruction", and the conversion of Dutch enterprises to corporate bodies subject to Indonesian laws. In still another move to mobilize public opinion, former Vice-President Hatta suggested that all of Indonesia come to a standstill for five minutes the day before the crucial vote in New York so that everybody could focus his thoughts on Indonesia's national claim to West Irian; such a demonstration of Indonesia's determination and solidarity would be more dignified than the painting of threatening slogans on the walls of Dutch houses, offices, and cars.

This was the national mood when on 29 November 1957 Indonesia lost the vote at the United Nations on the West Irian issue. What followed in Indonesia did not differ significantly from what had been predicted and promised in various quarters. In a nationwide broadcast on 30 November Prime Minister Djuanda exhorted the Indonesian people to keep their fighting spirit burning for the continuation of the struggle to regain West Irian from the Dutch on "another course". ${ }^{24}$ On 1 December Information Minister Sudibjo in his capacity as chairman of the West Irian Liberation Committee and with the approval of the cabinet 
called for a national twenty-four-hour strike the next day by all workers employed in Dutch enterprises. As of 2 December, Royal Dutch Airlines planes were banned from Indonesian territory. On 3 December laborers of the Dutch shipping line KPM seized control of the company's head office in Jakarta as their fellow employees did the same at KPM offices elsewhere in Indonesia. The KPM employees' action set the pattern for laborers in other Dutch companies throughout Indonesia in the days that followed. At first the government did nothing about these takeovers but on 4 December, in a speech before the National Reconstruction Conference, Sjafruddin Prawiranegara, Governor of the Bank of Indonesia and a Masyumi leader, warned that "disaster... might befall the Indonesian people in connection with the steps now being taken against the Dutch and their property in carrying out the current West Irian liberation campaign". Sjafruddin added, "I completely agree with the liquidation of all Dutch properties in Indonesia, but everything should be carried out according to a systematic plan and not just because of burning passions which might only stab the people themselves".

In the ensuing discussion of the matter, Sjafruddin maintained that the high-handed take-over of Dutch enterprises violated Articles 25 and 27 of the Indonesian Constitution, to which Prime Minister/Secretary of Defense Djuanda countered that his decree, issued on 29 November 1957 in his role as Central Military Administrator, had instructed the Chiefs of Staff of the three branches of the Armed Forces to channel all actions for the liberation of West Irian through the Central Action Committee for the Liberation of West Irian and that "up to now the government is still living up to this principle". The record, however, shows that the take-overs had caught the government by surprise, for all the orders and decrees issued in an effort to "legalize" the actions taken against Dutch enterprises were issued several days after the wave of unauthorized take-overs had begun to roll over Indonesia on 3 December.

On 5 December Justice Minister G.A. Maengkom pronounced any high-handed seizure of Dutch enterprises by trade unions a contravention of existing laws, stressing that only actions taken by the Central or Regional Military Administrators in order to supervise and protect Dutch enterprises in the interest of security and order could be justified. ${ }^{25}$ The same day, following a special meeting on the unauthorized take-overs, the cabinet released this communique: 
"The government realizes that the actions of the various groups in the community are the manifestation of a spirit which has been running since long ago and has now developed into a flood which must be properly channeled, so that it may truly become a properly co-ordinated and well-disciplined national potential for achieving the national goal, namely the restoration of West Irian under the sovereignty of the Republic of Indonesia.

With regard to the Dutch enterprises which have been taken over by the workers in the last few days, the cabinet has decided to put them under government control and to assign their management to a management board; in that way business will go on under government control." 26

The reassertion of government control of the take-overs came in a series of moves beginning with a nationwide broadcast appeal 6 December by Army Chief Staff and Central Military Administrator Major General Nasution to the people to refrain from arbitrary actions, which could not be condoned by the military authorities or the cabinet. Following the broadcast, Regional Military Administrator Gintings announced that all Dutch enterprises of East Sumatra would be under his direct supervision and that, to avert a bad impression on world opinion, the take-over of Dutch plantations and all other enterprises would henceforth be carried out in orderly manner and solely by the military. The next day Gintings proclaimed in a written statement that only an enterprise's administration was to be placed under military control. But on 9 December Prime Minister/Defense Minister Djuanda Kartawidjaja in his capacity as High Military Administrator issued a decree placing all Dutch plantations and agricultural estates - including their factories, agricultural research facilities, all other buildings, and movable as well as immovable goods - under the jurisdiction of the Republic of Indonesia and empowering the Minister of Agriculture to issue the necessary regulations. The Minister of Agriculture's implemental decree which was issued the following day, put the Dutch estates under the technical supervision of a new organization, PPN-Baru, whose nucleus came from the Government Estates Administration, or Perusahaan Perkebunan Negara (PPN), and the Estates Service or Jawatan Perkebunan. Also on 10 December the Chief of Staff of the Army, in his capacity as Central Military Administrator, issued an order to all Regional Military Administrators to take over the administration of any Dutch enterprises in their respective military territories in the name of the Republic of Indonesia. 
This order further directed that firm action be taken against any unauthorized take-over.

In a simultaneous move, Minister of Agriculture Sadjarwo called the representatives of the great Dutch plantation associations to a conference on 10 December to explain why the government felt compelled to take over the estates and what the decree meant for the Dutch owners. ${ }^{27}$ Insisting that the government's action was necessary in order to protect the factories and other installations of the estates during this period of political agitation so as to preclude interruption of production. Minister Sadjarwo assured this listeners that the Dutch enterprises had not been nationalized but remained the property of their Dutch owners under the supervision of PPN-Baru, which expected the cooperation of all Dutch personnel in maintaining the undisturbed operation of the plantations. His remarks provoked the rebuttal that the decree was nothing more than a one-sided governmental action with which the entrepreneurs were suddenly confronted and that the owners not only reserved all their rights under international law but would hold the Indonesian government responsible under the same international law for its action.

Then came the following series of questions:

"Who is responsible for the management of the estates after the enforcement of the decree issued by the Minister of Defense?" Sadjarwo: "The PPN-Baru. The former management is only the executor of orders given by the new administration".

"What happens to the power of attorney which the Dutch owners have issued to the directors or representatives residing in Indonesia?" Sadjarwo: "These powers will be taken over by the Indonesian government and will be transferred to PPN-Baru. The directors and representatives no longer have any voice in management, financing, and the like".

"Is the government prepared to guarantee the safety of Dutch personnel?" Sadjarwo: "I have brought this problem to the attention of Army Chief of Staff Nasution".

"Isn't there a contradiction between your hope that the plantation personnel will stay and the repatriation orders issued by other Indonesian authorities?" Sadjarwo: "The Indonesian government does not plan to order the repatriation of all Netherlanders at once, but will proceed in stages. The planters will not belong to the first groups. Their repatriation will depend upon their importance for the maintenance of production". 
"Have you taken full cognizance of the international character of ALS and AVROS?" Sadjarwo: "The government will certainly take this into consideration, but since Dutch interests predominate in both these organizations they too will be placed under government supervision". ${ }^{28}$

A second decree, ${ }^{29}$ issued on 11 December by the Minister of Agriculture, outlined the procedure for military administration of plantations and in East Sumatra the staff of Lt. Col. Gintings arranged a formal ceremony in the offices of the military prosecutor for Saturday morning, 14 December, at which regional civil and military authorities and representatives of various parties and mass organizations gathered to witness the signing of the transfer papers. After Gintings had read the decrees of the Minister of Defense and the Central Military Administrator, the company representatives were asked to sign the attendant legal documents - which all did, adding the letters "v.c." for "vi coactus" (under pressure) after their names. Gintings then signed each document on behalf of the Indonesian government. ${ }^{30}$

During a press conference on 17 December Prime Minister Djuanda stated that the government had learned that Dutch estates were being instructed by their directors in The Netherlands not to cooperate with the Indonesian management boards - since Indonesia had no intention of closing the Dutch plantations and a refusal to cooperate would not only harm the enterprises concerned but also Indonesia's economy. Furthermore, the plantations would be returned to the owners as soon as The Netherlands agreed to transfer sovereignty over West Irian to Indonesia. ${ }^{31}$

\section{The Dutch Plantations under Indonesian Management Prior to} Their Nationalization

Over five hundred Dutch estates, roughly three-fourths of all plantations in Indonesia, as well as a great number of other Dutch enterprises, had been put under military supervision by December 1957 - ironically on the basis of the colonial law regulating the state of war and siege which the Governor-General of the Netherlands Indies had signed on 13 September 1939. ${ }^{32}$ The first Indonesian legislation relative to the Dutch property issue came on 17 December 1957 with the promulgation of a series of laws including No. 74/1957 on the state of emergency and No. 79/1957 on the state of war. This new legislation 
entailed several changes in the existing regulatory system, e.g. because Article 60 of Law No. 74/1957 limited the validity of the decrees, ordinances, and instructions based on the prewar legislation to a period of four months, all documents connected with the actions taken after 1 December 1957 had to be rewritten to accord with the new Indonesian laws. ${ }^{33}$ More consequential, the new legislation made four distinctions - a "state of war", a "state of military emergency", a "state of civil emergency", and "a state free from emergency" - and made the military commander the highest authority in both civilian and military affairs of a region under a state of war or a state of military emergency and in military affairs alone of a region under a state of civil emergency or a state free from emergency. ${ }^{34}$

In view of President Sukarno's Decree No. 225 of 17 December 1957 which declared Indonesia to be in a state of war, ${ }^{35}$ this meant for East Sumatra a continuation of martial law with the regional military commander ranking in authority above the governor, the regimental commanders above the residents, battalion commanders above the bupati, and so on down the military and civilian hierarchy. Following the official transfer of the plantations to the military authorities, army officers were assigned to the various Dutch plantation companies in a supervisory and controlling capacity, in the expectation that the Dutch staff could be persuaded to continue its services under the new arrangement. What actually happened was that Dutch personnel began almost immediately to leave East Sumatra, precipitating near chaos on the plantations during the first months of 1958 as Indonesians with some practical experience but rarely any managerial training stepped into the vacancies left by their departure. (To help bridge the gap in their background PPN-Baru and the College of Agriculture in Bogor hastily organized special training courses for Indonesian plantation personnel.) AVROS changed its name to Sumatra Planters Association, or Gabungan Pengusaha Perkebunan Sumatera (Gappersu). M. Manik, a Simelungun Batak, replaced President Fernhout and J. Suleika replaced Rozendaal as the representative in Jakarta. From Singapore or The Netherlands, the top administrators of such tobacco companies as United Deli and Senembah and such rubber companies as Rubber Cultuur Maatschappij "Amsterdam" (RCMA) kept in close unofficial contact with select faithful members of their Indonesian personnel, who sent reports on operations and general conditions on their various estates. American, British, French, and Belgian estates also some- 
times served as links between the Dutch head offices and their "contacts" in East Sumatra. In addition, the Dutch companies received all Gappersu mailings.

One of the first letters sent to Medan by the new Gappersu representative in Jakarta, J. Suleika, concerned the target area maps which were supposed to have been in the hands of the Ministry of Agrarian Affairs by 2 November 1957. Very few if any of the companies had met that deadline and President Manik began prodding the member companies, though apparently with very little success. By 15 April 1958 only 21 and by 15 June only 52 of 250 plantations had submitted maps. In the case of the Indonesian managers of Dutch estates, there was the dilemma of having to clear such a map with the owners in The Netherlands or make decisions locally without proper authority - neither a palatable procedure. For non-Dutch plantations the former reluctance to indicate prematurely the land to be returned to the government now had to be weighed against the political hazards of appearing uncooperative.

When Suleika reported soon thereafter that Singgih's interdepartmental committee was about to recommend a combined target area of 386,000 hectares for annual and perennial-crop estates, President Manik protested the way his predecessor would have done. He objected particularly to the proposed reduction of the tobacco area from 113,000 hectares to 45,000 hectares, ${ }^{36}$ but Singgih's allocations in his plan for only 231,000 hectares for rubber, 11,000 hectares for tea, and 9,000 hectares for sisal and other fibers were just as disturbing. ${ }^{37}$ Though it is quite possible that Singgih threw out these figures merely to provoke counterproposals from East Sumatra, Manik reacted by referring Suleika to the previous agreements between the government and the Sumatran planters, which set far larger areas, and urging Suleika to protest that such a drastic reduction of the plantation area would not only violate the agreements but also jeopardize the economic foundations of plantation operations. Furthermore, Manik told Suleika, the Ministry of Agrarian Affairs should be informed that, as matters stood in East Sumatra, neither was there one local authority ready to eject squatters from target areas nor did the new managers of the Dutch plantations in their strictly supervisory capacity have the authority to release any land since property rights still rested with the Dutch companies. ${ }^{38}$

The squatter problem persisted and, if anything, grew worse under Indonesian military supervision of the Dutch plantations. 
Whereas by 1 October 1957 a total of some 121,400 hectares were occupied by squatters, the area had increased to 122,000 hectares by the end of 1957 and to 126,000 hectares by the end of 1958. The figures on annual expansion were 8,000 hectares in $1957,4,000$ in 1958 , and 5,000 hectares in $1959,{ }^{39}$ with BTI, Petani, and various veterans' organizations the chief instigators of the new squatting. Frequent references in the Medan press to arrests and trials of squatters during 1958 show that the police authorities and the courts did try, however, to stem the squatter movement.

Clashes between the autochthonous population and plantation laborers over the use of harvested tobacco fields had continued unabated and a particularly fierce one erupted in July 1958 as 500 estate workers battled, reportedly for an hour, with 100 villagers of kampong Kelambir on the ex-United Deli Company estate Bulu Cina in the kecamatan Hamperan Perak. Five workers and four villagers were injured slightly, one worker seriously wounded, and one villager killed. Three days later a fire destroyed one of the estate's tobacco drying sheds which at the time was filled with construction timber. Local rumors attributed the fire to villagers revenging their fellow villager's death. ${ }^{40}$

The incident evoked from Minister of Agrarian Affairs Sunarjo, member of the NU party, another ardent defense of the traditional jaluran rights of the autochthonous people and was the proximate cause for the appointment of a Committee for the Solution of Land Problems in North Sumatra (Panitya Penyelesaian Persoalan Tanah Sumatera Utara) by Gintings acting as Territorial War Administrator. ${ }^{41}$ This committee never met, because two days later, on 16 August 1958, Minister Sunarjo rescinded Gintings' order and appointed a more powerful Executive Committee for the Solution of Plantation Land Disputes in East Sumatra (Badan Pelaksana Penyelesaian Sengketa Tanah Perkebunan Sumatera Timur) with the governor himself as chairman and the head of the KRPT as vice-chairman. ${ }^{42}$ The rest of the committee, nine members and a secretary, comprised seven high provincial officials, one high army officer, and a member of the Provincial Council. It was indicative of the drastic changes in the political climate of Indonesia since December 1957 that there was no representative from any peasant organization. ${ }^{43}$

Once the army took over the supervision of plantation management its officers became directly involved in labor and squatter disputes and, accustomed to military discipline rather than to the give-and-take of the bargaining their predecessors had been 
forced to accept, relied more and more on the "state of war" regulations to impose solutions by military order. Thus strikes were outlawed in order to prevent a decline in production, wage increases for plantation workers peremptorily held to a minimum, and tractors ordered in to level the crops and buildings of squatters wherever the squatters did not have the protection of a standfast or where the management board of an estate deemed squatter holdings to be seriously interfering with operations. Similarly, army officers in Gappersu simply overruled the representatives of British, Belgian, and American companies if a proposed action would raise the costs of production. There was of course no place in this authoritarian pattern for the political accommodation of the peasant leaders and their costly demands.

Yet only half a year earlier Minister of Agriculture Sadjarwo had appointed an Advisory Board of the PPN-Baru, whose composition was quite the reverse, ${ }^{44}$ on matters pertaining to workers' and peasants' welfare and the productivity of estate laborers. Of the eight members serving under a representative of the Ministry of Labor as chairman and a representative of the Ministry of Agriculture as vice-chairman were three representing labor organizations, three representing peasant organizations, and one delegate each from PPN-Baru and the Ministry of Agrarian Affairs. (Another striking aspect was the strong representation of laborers and peasants both at the central and territorial level, the latter in anticipation of the territorial advisory committees being planned in connection with all PPN-Baru provincial offices.) A possible explanation for Sadjarwo's disregard of the new military presence is his own political background. A former member of the BTI, Sadjarwo joined Djuanda's cabinet in April 1957 as a nonparty member but was listed as a member of the PNI by the time Djuanda reorganized his cabinet in June 1958. Whatever the explanation, Sadjarwo was looking for cooperation between PPN-Baru, laborers, and peasant-squatters.

The army took advantage of every opportunity to place officers in government agencies concerned with the administration of Dutch properties. In June 1958, for example, Nasution in his capacity as Central War Administrator (Penguasa Perang Pusat) assigned officers to the Central Administrative Committee of Dutch Industrial and Mining Enterprises, or Badan Pusat Penguasa Perusahaan-perusahaan Industri dan Tambang Belanda (BAPPIT), the Committee for Trade Matters, or Badan Urusan Dagang (BUD), and PPN-Baru. His instruction contained guidelines for cooperation between the Central and Territorial 
War Administrators on the one hand and PPN-Baru on the other. Even more explicit was Nasution's order that the deputy director of the PPN-Baru headquarters in Jakarta be an army officer responsible directly to the office of the Central War Administrator and appointed by the Prime Minister. Similarly, the deputy director of a provincial branch of PPN-Baru had to be an officer acting as the representative of the Territorial War Administrator. ${ }^{45}$ In these ways the army filled key positions in all the agencies concerned with the supervision and management of Dutch enterprises - and army officers accrued great material advantages in these positions.

The functions, rights, and duties of those assigned to the plantations were detailed in an instruction issued by Nasution on 18 September 1958. Their primary task was to reorganize the administrative structure, to normalize and improve the enterprise, and to carry through the "Indonesianisation" of the personnel. In the field of personnel and labor relations their authority was complete, from control of appointments, promotions, and dismissals of the staff to initiation of measures to ensure cooperation among laborers, staff, and management. These army officers also controlled finances, countersigning every bank check. Housing, transport, maintenance of equipment and buildings all came under their management and it was their duty to oversee any sales of property and interdict those that would cause losses to the enterprise. In short, not a single aspect in the business life of the estates or other enterprises was outside the assignment of these officers.

\section{Nationalization}

As the year 1958 advanced with no sign that The Netherlands was going to yield to Indonesian economic pressure, the labor unions and other mass organizations began to clamor for nationalization of all Dutch enterprises in furtherance of the revolution. On 15 November 1958 Nasution officially transferred the supervision of Dutch enterprises from military to civilian authorities at a ceremony in the Headquarters of the Army Chief of Staff attended by Prime Minister Djuanda and several ministers. Extraordinary circumstances, Djuanda noted in his remarks, had made military control of the estates necessary initially but with the return to normal conditions it was important that Dutch enterprises be under the supervision of civilian administrators. The Dutch plantations would thereafter come under the Minister 
of Agrarian Affairs and his agency, the PPN-Baru. General Nasution stressed that the take-over of the Dutch enterprises was a political instrument in the struggle for West Irian and voiced the hope that the enterprises would not become a political instrument in the hands of groups endangering the national economy, a danger only continued civil-military cooperation in the supervision of these enterprises would avoid. After the transfer, army officers went on inactive status while assigned to a Dutch estate or other enterprise and in many instances retired army officers were called to this duty, often effecting a striking increase in the size of an estate's staff.

Also in November 1958 the cabinet submitted a draft nationalization bill, which parliament, in record time (on 3 December), approved with little or no debate. President Sukarno signed Law No. 86 concerning "Nationalization of Dutch-owned Enterprises in Indonesia" on 27 December, to be retroactive to 3 December 1957.46 The preamble states that nationalization constitutes "part of the struggle for the liberation of Irian Barat" and is to be considered "consistent with the policy of annulling the Round Table Conference agreements". Article 2 provides for compensation of the former owners and gives the latter the right to seek remedy in Indonesian courts in case of dissatisfaction with the offered compensation. Explanatory notes give the new law's aims to normalize the well-being of the Indonesian people, to strengthen the national potential, and to abolish economic discrimination and economic-colonial subjugation. In a series of implemental ordinances that followed, every Dutch enterprise to which the law applied, was identified. Seventeen tobacco estates of the United Deli Company, five estates of the Senembah Company, and a total of 16 tobacco estates in Java were listed as subject to nationalization. ${ }^{47}$ Of some seventy-six perennial-crop estates identified in North Sumatra, including Aceh, fifty-four produced rubber, thirteen oil palm, five tea, and four sisal and other fibers. Among the more important companies named were United Deli (twelve estates) and Senembah (four estates counting their perennial-crop estates), HVA (four estates), Rubber Cultuur Maatschappij "Amsterdam" (twelve estates), and Nederlandsche Handel Maatschappij (NHM) (four estates). ${ }^{48}$

A note of protest to the Indonesian government was delivered on 28 February 1959 by the Chargé d'Affaires of the Netherlands Diplomatic Mission in Jakarta in which pointed reference was made to the Netherlands government's previous note of 16 September 1958 regarding earlier measures taken against Dutch 
interests in Indonesia. The Hague argued that Indonesia had violated the "fundamental principles of international law as well as of obligations voluntarily accepted by Indonesia under the United Nations Charter and by treaty". In its reply of 8 October 1958 , so recalled the Dutch note, Indonesia had ignored the Netherlands government's legal arguments, merely stating that Indonesia could not discuss the financial and economic interests of The Netherlands in Indonesia so long as the dispute over West Irian had not been solved. The nationalization was "likewise at variance with the generally recognized rules of international law. Under these rules any infringement of the property rights of aliens is anyhow unlawful when accompanied by discrimination. The unlawful character of the Nationalization Act is also evident from its own preamble. The Act is impeached by the preamble since in it it is stated that the Act is intended as a means for exerting pressure in a political dispute, namely the dispute about Netherlands New Guinea." The Indonesians could "neither annul nor transfer the property and other rights of Netherlands nationals owning property in Indonesia, either natural or legal persons" and this applied as well to the produce of this property. (This last reference played an important role in lawsuits presented to the courts of Bremen in 1959.) The Dutch note also referred to the Indonesian intention of postponing the payment of compensation until such a time as the political dispute had been solved to Indonesia's satisfaction. ${ }^{49}$

In reply, the Indonesian government held that it was the sovereign right of a state to decide on such matters as the nationalization of alien property and the fact that the Nationalization Act recognized the obligation to pay compensation to the former owners justified the Act as a lawful measure. Elaborating on this, Minister of Agriculture Sadjarwo told reporters at a press conference in July 1959 that

"the developments in the Indonesian-Dutch dispute over West Irian last year had only precipitated the decolonization process of Indonesia's economy... though Indonesia's independence was recognized in 1949, the country's economic structure had remained colonialist in spite of the political freedom. The Dutch still retained their economic privileges and the Indonesian economy was still under their control by virtue of the Round Table Conference agreements, which had been concluded when Indonesia was in a disadvantageous bargaining position. The Dutch hold over the economy also entailed discrimination against the economic interests of other foreign nations." 50 


\section{NOTES}

\section{CHAPTER I}

1 Karl J. Pelzer, Planter and Peasant, Colonial Policy and the Agrarian Struggle in East Sumatra 1863-1947, The Hague, 1978, p. 134-35.

2 The members of this committee, all relatives of sultans or of minor rulers, were: Tengku Mansur, Tengku Hafaz, Tengku Dzulkarnain, Datuk Hafiz Haberham, Djomat Purba, Raja Sembiring Meliala also known as Ngeradjai Meliala, Tengku M. Bahar, Djaidin Purba, Raja Silimahuta, Raja Kaliamsjah, Madja Purba, Anak Raja Panei, and Crang Kaja Ramli (Medan Bulletin, 2, No. 173, 1 August 1947). Their petition to the Netherlands Indies government was based on Article 3 of the Linggarjati Agreement: The United States of Indonesia shall comprise the entire territory of the Netherlands Indies with the provision, however, that in case the population of any territory, after due consultation with the other territories, should decide by democratic process that they are not, or not yet, willing to join the United States of Indonesia they can establish a special relationship for such a territory to the United States of Indonesia and to the kingdom of the Netherlands.

3 Medan Bulletin, 2, Nos. 223 and 240.

4 A. Arthur Schiller, The Formation of Federal Indonesia, 1945-1949, The Hague, 1955, pp. 155-58.

5 Pemandangan ringkas ekonomi dan tata Negara Soematera Timoer - Staatkundige en Economische Schets van Negara Soematera Timoer, Medan, 1948.

6 Tengkoe Mansoer, "Oost-Sumatra in een nieuwe gestalte", Indonesië, 2 (1948-49), pp. 97-100.

7 Tengkoe Mansoer, "Oost-Sumatra in een nieuwe gestalte", p. 100.

8 Instruction issued by the Republican Resident in Pematangsiantar, 1 May 1947, No. 1138/VI/16.

9 Ordonnantie onrechtmatige occupatie van gronden, Staatsblad 1948, No. 110.

10 J.H. de Haan, Reisrapport No. 14 van het Hoofd van het Bureau der Landinrichting naar de Negara Sumatera Timur van $19 \mathrm{t} / \mathrm{m} 30$ October 1948, pp. 10-11.

11 J.H. de Haan, Rapport No. 26, reis naar Medan van 11-15 April 1950, pp. 4-5.

12 See Pelzer, Planter and Peasant, Table 15, p. 106.

13 The Javanese who settled in the Pertuhanan Huta Bayu Merubun agreed to live according to Simelungun adat and, to this end, formed their own marga. This was named Sinaga Tambah to show their status as a submarga of the Simelungun marga Sinaga (tambah means to add or to increase). 


\section{CHAPTE R II}

$1 \mathrm{R}$. Soepomo, De reorganisatie van het agrarisch stelsel in het gewest Soerakarta, 's-Gravenhage, 1927.

2 G. Schwencke, Het Vorstenlandsche grondhuurreglement in de practijk en het grondenrecht in Jogjakarta, Yogyakarta, 1932, pp. 142-43.

3 The distribution of water in Java was once the prime source of agrarian discontent.

4 It may be better to speak of the right of regulating land use, since the community does not have the right of disposal in the sense of alienation.

5 B. ter Haar, Adat Law in Indonesia, New York, 1948, pp. 81-100.

6 Conversation with the late Haji Agus Salim.

7 In the last century the Netherlands Indies government set the rental at one guilder per hectare. This rate was never changed. After the transfer of sovereignty the Indonesian government collected annually one Rupiah per hectare, although the currency lost most of its former value. Not until after the abrogation of the Round Table Conference agreement in 1956 was the rate changed, so that for several years the planters paid practically no rental for their land.

8 Suara Tani, 1958.

9 A. Doak Barnett, Echoes of Mao Tse-Tung in Djakarta, An Interview with D.N. Aidit, Secretary General of the Indonesian Communist Party, American Universities Field-Staff, Indonesia, ADB-6-'55.

\section{CHAPTER III}

1 Bintang Merah (December 1951), pp. 15-22; Aidit in Bintang Merah (July 1953), pp. 332-40.

2 Among these slogans, as given in Bintang Merah (July 1953), p. 339, were: Lower land rents; Reduce loan interests; Lower state taxes; Cancel arrears in land tax; Abolish compulsory payment (setoran paksa); Abolish unpaid village labor; Abolish compulsory labor on roads; Don't touch land that is cultivated by peasants; Give the peasants the right to negotiate the rent for land leased by foreign estates; Arm the peasants in order to crush the Darul Islam (DI), Tentara Islam Indonesia (TII), and other terrorist gangs; Assist peasants with seed and tools; Each kecamatan its own agricultural school; Abolish the slaughter fee; Abolish the fee for the identification certificate; Improve old irrigation systems and construct new ones; and Form a village government which defends the people.

3 D.N. Aidit, Problems of the Indonesian Revolution, Bandung, 1963, pp. 252-53.

4 Partai Komunis Indonesia, "Laporan Mengenai Pekerdjaan Partai Dikalangan Kaum Tani”, Bintang Merah (April-May 1959), as quoted by Donald Hindley, The Communist Party of Indonesia 1951-1963, Berkeley-Los Angeles, 1964, p. 164.

5 D.N. Aidit, Kaum Tani Mengganjang Setan-Setan Desa, Jakarta, 1964, pp. 19-27.

6 The kaum kapitalis birokrat are the officials of State Commercial Enterprises (Perusahaan Dagang Negara, PDN), State Enterprises (Perusahaan Negara, PN), and Government Estates Administration (Pusat Perkebunan 
Negara, PPN). "Village bandits" are individuals who serve as guards for landlords, bureaucratic capitalists, and managers and who commit crimes against the peasants in the interest of their exploiters.

7 Aidit, Problems of the Indonesian Revolution, p. 37.

8 Aidit, Problems of the Indonesian Revolution, p. 424-25.

9 Aidit, Kaum Tani Mengganjang Setan-Setan Desa, pp. 20-21.

10 Aidit, Kaum Tani Mengganjang Setan-Setan Desa, p. 22-23.

11 Aidit, Problems of the Indonesian Revolution, p. 422.

12 Aidit, Kaum Tani Mengganjang Setan-Setan Desa, p. 18.

13 Partai Komunis Indonesia, Tuntutan untuk Bekerdja Dikalangan Kaum Tani, Jakarta, 1955, p. 44.

14 Aidit, Problems of the Indonesian Revolution, p. 425-426.

15 Hindley, The Communist Party of Indonesia, pp. 175, 340-41 note 68.

16 Dare, Dare, and Dare Again: Political Report Presented on February 10, 1963 to the First Plenary Session of the Seventh Central Committee of the Communist Party of Indonesia, Peking, 1963.

17 Aidit, Problems of the Indonesian Revolution, p. 524.

18 Aidit, Problems of the Indonesian Revolution, p. 524-5.

19 Aidit, Problems of the Indonesian Revolution, p. 526.

20 Aidit, Kobarkan Semangat Banteng! Madju Terus, Pantang Mundur!, p. 21, as quoted by Justus M. van der Kroef, “Indonesian Communism's 'Revolutionary Gymnastics' ", Asian Survey, 5 (1965), 220.

21 Indonesian Observer (July 10, 1964).

22 Van der Kroef, "Indonesian Communism's 'Revolutionary Gymnastics' ", p. 220.

23 Antara (Cologne), v. 16, n. 3661 (November 13, 1964).

24 Suluh Indonesia (December 5, 1964).

25 Antara (Cologne), v. 16, n. 3818 (June 4, 1965).

26 Among the founders were Mohammad Tauchid and Sadjarno, the latter an employee of the Land Tax Office in Surakarta.

27 Since the traditional markets for sugar and tobacco were inaccessible, the Japanese shifted to the cultivation of such fibers as cotton, ramie, and rosella and to the production of castor beans, the source of lubricating oil; John O. Sutter, Indonesianisasi: Politics in a Changing Economy, 1940-1955, Ithaca, N.Y., 1959, 1, 151, 156-58.

28 Hindley, The Communist Party of Indonesia, p. 165. The BTI leadership, however, included men like Mohammad Tauchid who were members of the Indonesian Socialist Party.

29 New York Times (November 6, 1965).

\section{CHAPTER IV}

1 The articles were numbered 27, 29, and 33 in the Constitution of 1945 and became articles 7,18 , and 38 respectively in the Provisional Constitution of 1950. Some modifications were made in the first two but the third was unchanged. An English translation of the Provisional Constitution of 1945 was published in Voice of Indonesia, October 1945; the Indonesian and Dutch versions can be found in W.A. Engelbrecht, $\mathrm{Kitab}^{2}$ Undang $^{2}$, Undang ${ }^{2}$ dan Peraturan ${ }^{2}$ serta Undang ${ }^{2}$ Dasar 1945 Republik Indonesia, Brussels-Leiden, 1960, pp. 34-42. On 5 July 1959 the Republic of Indonesia returned to the Provisional Constitution of 1945. 
2 Personal communication from the former Sultan of Deli.

3 Sarimin Reksodihardjo had been the head of the Agrarian Section in the Ministry of Interior of the Republic of Indonesia before 1950 and had served as chairman of the Panitya Agraria Yogyakarta. In 1950 he was head of the Agrarian Service of the Ministry of Interior of the Republic of the United States of Indonesia.

4 Urgency Program of 20 July 1950 (Urgensi-Program PPNKST, Tanggal 20 Djuli 1950).

5 The instructions, drafted by Abdul Hakim, a senior official of the Ministry of Interior who was attached to Sarimin's staff, were entitled Tjara Melaksanakan Urgensi-Program PPNKST, Tanggal 20 Djuli 1950, jang mengenai fatsal IV Soal Agraria dan Ekonomi and were published at Medan, 26 September 1950. This document is reproduced as Appendix 7 to Pelaporan dengan Pertimbangan-Pertimbangan serta Usul-Usul dari Panitya Negara Urusan Pembagian Tanah Perkebunan Sumatera Timur, Jakarta, 1954.

6 This summary is based on an unpublished working paper entitled: Beknopte samenvatting van de huidige stand van het agrarisch vraagstuk in de Deli-tabaksstreken en uitstippeling van een onderhandelings- en werkbasis voor de Regering.

7 Pengumunan No. 1219/IV, Medan, 28 September 1950.

8 Unpublished report entitled: Vergadering betreffende het Grondenprobleem in het Tabaksgebied, gehouden op 24 Maart 1951 ten kantore van de Djawatan Perkebunan te Djakarta.

9 Decree Agr. 12/5/14, 28 June 1951.

10 Decree No. UP/5/3/27, 27 June 1951.

11 Decree No. 36/K/Agr., 28 September 1951.

12 I.J. Kasimo, a prominent Catholic politician, member of parliament of the Republic of the United States of Indonesia and member of Sekata, identified most of these; the remainder were included on the basis of newspaper articles and other contemporary sources.

13 Suara Rakjat, 12 and 13 April 1950. A copy of this report was circulated among planters of East Sumatra.

14 Waspada, 30 March 1951.

15 This explains why the tobacco companies continued to pay the annual ground-rent for the total concession area rather than the 125,000 hectares earmarked for their exclusive use.

16 Suara Rakjat, 19 October 1951.

17 They were BTI, RTI, Perti, Gaperta, and Gabungan Buruh Tani Tionghoa. The statement is included as Appendix 12 to Pelaporan... Panitya Negara Urusan Pembagian Tanah Perkebunan Sumatera Timur.

18 Order No. 26/K/Agr., 15 August 1951.

19 On 2 January 1951 the acting governor of North Sumatra canceled Decree No. 1138/VI/16 which had been issued 1 May 1947 by the Resident of East Sumatra.

20 Rentjana Tuntutan Pekerdjaan Melaksanakan Pembahagian Tanah untuk Taraf Pertama, Medan, 11 February 1952.

21 Mestika, 21 June 1952.

22 Suara Rakjat, 4 March 1952, carried an account of a Petani meeting at which the speakers protested the discrimination against plantation workers who had become subsistence farmers during the war or the 
revolution. See also Suara Rakjat, 21 April 1952.

23 Suara Rakjat, 26 March and 2, 19, 21, and 25 April 1952.

24 Ichtisar Parlemen, 1952, pp. 249-51.

25 Kasimo was referring to the letter No. 22063/3/6 and directive No. Agr. $12 / 4 / 16$ of 28 May 1952 sent by the Ministry of Interior to Governor Hakim.

26 Suara Rakjat, 4 March 1952; Mimbar Umum, 9 May 1952.

27 Waspada, 30 May 1952.

28 Letter No. 22063/3/6 and directive No. Agr. 12/4/16; Mestika, 17 June 1952.

29 Waspada, 4, 5, 6, 7, 9, and $10 \mathrm{June} 1952$.

30 Waspada, 9 June 1952.

31 Mestika, 18, 19, 20, and 21 June 1952.

32 Letter of Munar S. Hamidjojo No. 976/KPPT, dated 31 May 1952, reprinted in Ichtisar Parlemen, 21 May 1953.

33 Geraktani, KTI, STII, and BPRP did not attend since they opposed policies pursued by BTI. Petani, too, was not represented in the congress, but this peasant union joined the Sekretariat Bersama shortly after the congress.

34 Waspada, 26 February 1953.

35 Waspada, 7 and 9 March 1953.

36 Waspada, 11 March 1953.

37 Waspada, 30 December 1952.

38 See, for example, "Agrarian Structure and Reform in Indonesia", ECAFE Tsuchin No. 145 (Tokyo), 21 January 1958.

39 Tangkas, 17 March 1953, reported that the Chinese attacked the police shouting, "Attack! Life or death for Stalin!"

40 The account presented here follows the one given by Mohamad Roem, Minister of Interior, to a parliamentary committee. See also, Tangkas, 17 March; Keng Po, 21 March; and Waktu, 2 May 1953.

41 Antara, 22 March 1953.

42 Chairman of the committee was Ersat Trunodjojo of Masyumi; secretary was Abdullah Jusuf of PNI; members S. Sardjono and Mohammad Tauchid belonged to BTI, Maizir Achmaddyn to Masyumi. Trunodjojo, Tauchid, and Achmaddyn supported the Minister of Interior and the governor; Jusuf and Sardjono were highly critical and opposed the whole agrarian program. In September 1953 Mohammad Tauchid broke with BTI.

43 Mimbar Umum, April 1953.

44 Mimbar Umum, 7 April 1953.

45 Herbert Feith, The Wilopo Cabinet, 1952-1953: A Turning Point in Post-Revolutionary Indonesia, Ithaca, N.Y., 1958.

\section{CHAPTER V}

1 The appointments were as follows:

1 Subakti Pusponoto, Resident and Acting Governor of Central Java (Chairman). He became sick, left for Java in May, and did not return. His duties were assumed by the Vice-Chairman.

2 Singgih Praptodihardjo, Ministry of Agrarian Affairs, Jakarta (ViceChairman). 
3 Radjamin, Ministry of Agriculture and Chief of Tata Bumi, Medan.

4 S.M. Tarigan, representing the Joint Secretariat of Peasant Organizations for the Settlement of the Agrarian Problem in North Sumatra (Sekretariat Bersama Organisasi Tani untuk Penyelesaian Tanah Sumatera Utara) in Medan.

5 Sjamsul Bahri, representing the Indonesian Islamic Peasant Union (Sarekat Tani Islam Indonesia, or STII), Sumatera Utara, in Medan.

6 Abdul Kadir, representing the Council for the Struggle of the Autochthonous Population (Badan Perjuangan Rakyat Penunggu, or BPRP).

7 Abdul Djafar, representing the Government Estates Administration (Pusat Perkebunan Negara, or PPN).

8 R. Nolen, head of AVROS, representing the perennial-crop estates.

9 E.M. Vorstman, representative of the United Deli Company, representing the tobacco estates.

10 Asjro Effendi, representing the Sekretariat Bersama (see Tarigan, 4, above).

11 Amiruddin Tito, representing the Sekretariat Bersama.

12 J.M. Simbolon, representing the Sekretariat Bersama.

13 Zainal Abidin, representing STII, North Sumatra.

14 Kongsi Semiring Depari, representing the BPRP.

15 Soerdjadi, representing the Council of Cooperating Peasant Organizations of North Sumatra (Badan Kerdja-Sama Organisasi Tani Sumatera Utara, or BKOTSU).

In addition, the following two staff appointments were announced:

Iman Supangat Sastrohadiprodjo, chief of subsection Agrarian Policy, Ministry of Agrarian Affairs, Jakarta (First Secretary).

M. Parlindungan, chief of the Agrarian Section for the province of North Sumatra (Second Secretary).

2 See Memorandum inzake "De Richtlijnen voor de Staatscommissie voor de verdeling van ondernemingsgronden ter S.O.K.". This memorandum was prepared by the Agrarian Committee of AVROS and distributed to the officers of the organization as an appendix to a letter of 4 May 1954.

3 The tension between Subakti and Singgih is believed to have greatly contributed to Subakti's decision to obtain a doctor's certificate and not to return to Medan at the end of puasa in mid-June. For a brief period in June, Singgih showed a more objective behavior - possibly in response to criticism expressed by Minister Hanafiah - but by July he was acting once more "as if he were a member of the 'Sekretariat Bersama"'; R. Nolen in a letter of 4 August 1954.

4 Algemene Verklaring: Particuliere ondernemers in de Staatscommissie voor de verdeling van ondernemersgronden in Sumatera Timur, Medan, 26 March 1954 (mimeo).

5 Memorandum inzake het Grondenvraagstuk in Sumatera Timur, Medan, 17 June 1954 (mimeo).

6 Algemene Beschouwing over de Wijze van Oplossing van het Grondenvraagstuk ter Oostkust van Sumatra, Appendix III of R. Nolen's letter, Medan, 26 April 1954. (Indonesian text, Pemandangan umum untuk djalan penjelesaian masaalah tanah di Sumatera Timur, Medan, 16 April 1954, Appendix 21 of Pelaporan dengan Pertimbangan-Pertimbangan 
Serta Usul-Usul dari Panitya Negara Urusan Pembagian Tanah Perkebunan Sumatera Timur.)

7 R. Nolen's letter of 4 August 1954.

8 Keterangan Umum para Wakil dari "Badan Perdjuangan Rakjat Penunggu Indonesia Sumatera Timur" dalam Panitya Negara untuk Pembagian Tanah Perkebunan di Sumatera Timur, 12 April 1954, Appendix 20 of Pelaporan ... dari Panitya Negara.

9 Ichtisar, p. 7, in Pelaporan ... dari Panitya Negara.

10 Persoalan Pendudukan Tanah Perkebunan di Sumatera Timur, Appendix 30 of Pelaporan ... dari Panitya Negara.

11 Konsepsi mengenai soal pembagian tanah-tanah konsesi perkebunan Sumatera Timur, Appendix 22 of Pelaporan ... dari Panitya Negara.

12 K. van der Molen's letter of 3 May 1954 to Abdul Djafar, head of PPN (Government Estates Administration) in Medan and member of the state commission.

13 The alternating hope and frustration of Nolen over the outcome of the sessions, and reports of his clashes with Tarigan and Singgih, can be read in his letters to the AVROS Board of Directors dated 24 April, 4 August, and 10 August 1954.

14 The report is available in both Indonesian and Dutch: Pelaporan dengan Pertimbangan-Pertimbangan Serta Usul-Usul dari Panitya Negara Urusan Pembagian Tanah Perkebunan Sumatera Timur (44 pp. and 33 appendices, mimeo); and Rapport alsmede Adviezen en Voorstellen van de Staatscommissie voor de Verdeling van Ondernemingsgronden in Sumatera Timur ( $30 \mathrm{pp}$. and only 5 of the 33 appendices, mimeo).

15 See, for example, AVROS letter No. 151, 25 January 1954, addressed to the Governor of the Province of North Sumatra.

16 AVROS letter No. 397, 1 March 1954, addressed to the Attorney General of the Republic of Indonesia, Jakarta.

17 Maklumat No. 1138/XXV/KPPT.

18 Maklumat No. 1416/XXV/KPPT.

19 Maklumat No. 33966/3.

20 AVROS letter No. 1207, 19 July 1954.

21 Letter No. 3068/XXV/KPPT, Medan, 31 August 1954.

22 Maklumat No. 4393/XXV/KPPT.

\section{CHAPTER VI}

1 Kort Verslag bezoek Minister Agrarische Zaken (appended to AVROS letter No. 26/Bl., 7 February 1955).

2 Kort Verslag bezoek Minister Agrarische Zaken.

3 Decree No. Agr. 12/5/14.

4 Decree No. 36/K/Agr.

5 Text will be found in the Minutes of the Board of Directors Meeting of 15 May 1955.

6 AVROS letter No. 750, 19 May 1955.

7 Letter Ka 12/2/16, 26 May 1955.

8 Letter No. 121, 3 June 1955, addressed to the attention of Singgih Praptodihardjo, Ministry of Agrarian Affairs. See AVROS letter, Medan, 7 June 1955.

9 AVROS letter No. 891, 16 June 1955. 
10 Interne Nota t.b.v. Dagelijks Bestuur inzake Agraria, 20 August 1955.

11 Nota inzake Gezamenlijk Besluit No. 1/1955, d.d. 30 June 1955 van de Ministers van Agraria, van Landbouw, van Economische Zaken, van Binnenlandse Zaken en van Justitie, Medan, 29 August 1955 (mimeo).

12 AVROS, Memorandum inzake de uitvoering van de Noodwet No. 8/1954, Medan, 6 September 1955 (mimeo); also issued as an appendix to AVROS letter No. 163/Bl., Medan, 6 September 1955.

13 AVROS, Memorandum betreffende het agrarisch probleem in Sumatera Timur, October 1955; also issued as an appendix to AVROS letter No. 188/Bl., Medan, 12 October 1955.

14 Memorandum nopens de Toepassing van de Strafbepalingen tegen "Onwettige Occupaties" in de Noodwet No. 8/1954 (appended to AVROS letter No. 17/Bl., Medan, 17 January 1956).

15 Resumé van het besprokene op de vergadering der Agrarische Commissie der Contactcommissie Grootlandbouw-organisaties, gehouden op 27 January 1956 (mimeo).

16 This is illustrated by an article in Medan's Tangkas, 29 February 1956, citing a resolution passed by the directors of the Gerakan Tani Indonesia in Bogor on 27 February 1956.

17 The problems of expired concessions were discussed in AVROS letters No. 32/Bl., 2 February 1956; No. 46/Bl., 8 March 1956; No. 58/Bl., 3 April 1956; and No. 103/Bl., 6 June 1956; as well as in a legal memorandum prepared by W.J. Borgerhoff Mulder, dated Klein Sungei Karang, 10 April 1956, and deposited in the AVROS archive in Medan. See also Pendorong, 1 June 1956, and Mestika, 30 May 1956.

18 Pendorong, 7 April 1956.

19 See, for example, the editorials in Tjerdas, 20, 21, and 30 April 1956, and in Tangkas, 19 April 1956.

20 Mestika, 6 April 1956.

21 Pendorong, 2 May 1956.

22 AVROS letter No. 808, Medan, 3 July 1956 (attached to AVROS letter No. 126/Bl., Medan, 4 July 1956).

23 Tjerdas, 23 July 1956.

24 AVROS letter No. 953, Medan, 1 August 1956; this letter was also attached to AVROS letter No. 150/Bl., Medan, 3 August 1956.

25 Mimbar Umum, 31 October 1956.

26 Lembaga, 23 November 1956.

27 AVROS letter No. 236/Bl., Medan, 21 November 1956.

28 AVROS letter No. 234/Bl., Medan, 16 November 1956.

29 Minutes of the Board of Directors Meeting of 4 December 1956.

30 Minutes of the Board of Directors Meeting of 29 December 1956.

31 Some ten years later, in January 1967, when I interviewed the retired Tengku Kotjik about this incident, he recalled that the PKI and the BTI had made every effort to block this project for political reasons but had failed to win the support and cooperation of the squatters. For them the choice was between illegally occupying other estate land or moving with government assistance to land to which they would receive agrarian rights.

32 The eight organizations were: Petani, STII, GTI, BPRP, Sakti, Gaperta, BPRTI, and BPR.

33 Petani and GTI continued to oppose such agreements. 
34 Lembaga, 31 July 1957, reported the arrest of 65 members of the BTI because of illegal occupation of land belonging to the United Deli Company estates of Bulu Cina and Paya Bakung.

\section{CHAPTE R VII}

1 Herbert Feith, "Dynamics of Guided Democracy", in Indonesia, ed. Ruth T. McVey, New Haven, 1963, pp. 332-34.

2 Pengumuman, No. Peng/00001/1/1957.

3 Surat Keputusan, No. KPTS 0030/1/57.

4 AVROS letters No. 44/AH., Medan, 16 February 1957, and No. 59/AH., Medan, 12 March 1957.

5 Maandberichten van de Algemeene Vereeniging van Rubberplanters ter Oostkust van Sumatra, No. 4 (1957), p. 6.

6 Suxat Keputusan, No. PM/KPTS 0007/5/57.

7 The Indonesian text together with a Dutch translation were sent to the Board of Directors with AVROS letter No. 87/Bl., Medan, 19 June 1957.

8 See, for example, Lembaga and Mestika, 28 June 1957.

9 AVROS letter No. 897, 26 July 1957 (distributed to the members with letter No. 153/AH., Medan, 20 August 1957).

10 Rozendaal's letter No. 842/M, Jakarta, 10 September 1957.

11 A "target area" is that part of a plantation which the planter regards as the minimum necessary for its continued operation.

12 The law gives each member of the permanent labor force the right to ask for a garden not less than 200 square meters and not more than 600 square meters.

13 Resumé van de Vergadering van het Bestuur der Algemeene Vereeniging van Rubberplanters ter Oostkust van Sumatra (AVROS), gehouden op Woensdag, 11 September 1957, Medan, 12 September 1957 (mimeo).

14 Samenvatting van de besprekingen vertegenwoordigers ministeries op het hoofdkwartier van de Landmacht op 11 September 1957 bij wijze van recommandatie aan de Centrale Militaire Gezaghebber, Jakarta, 11 September 1957. This document was attached to AVROS letter No. 142/Bl., Medan, 21 September 1957.

15 The AVROS delegation included J. Fernhout, G. van Wezel, D. van Eck, J.D. Schoon and F. Benders.

16 Unpublished minutes headed "Resumé van de Buitengewone Algemene Ledenvergadering, gehouden op Vrijdag de 27 September 1957".

17 Minister Sunarjo's letter No. Ka 13/19/5 of 2 October 1957 was distributed to all AVROS members together with AVROS letter No. 210/Ah., Medan, 18 October 1957.

18 The composition, as listed in AVROS letter No. 165/Bl., Medan, 22 October 1957, was:

Singgih Praptodihardjo, Chairman Ministry of Agrarian Affairs M. Hardjoamidjojo, Vice-Chairman Ministry of Agriculture

Saleh Wariatmadja, Member

Ir. Agus Prawiranata, Member

M. Muntoha, Member

Gozali, Member

Sosroharsono, Member
Ministry of Agriculture

Ministry of Public Works

Cadastral Service

Ministry of Labor

Ministry of Social Affairs 
Sumitro Tjokrowardojo, Member Ministry of Agrarian Affairs Major Sukardi, Member Headquarters, Army Chief of Staff S. Anwar Kasim, Member Ministry of Agrarian Affairs

19 This explains the striking difference between the first draft, given in AVROS letter No. 168/Bl., 25 October 1957, and the final letter No. 239, addressed to the Minister of Agrarian Affairs on 31 October 1957 and attached to AVROS letter No. 219/AH., Medan, 5 November 1957.

20 Persbiro Indonesia-Aneta, 22 October 1957.

21 Persbiro Indonesia, Weekly Airmailer, Jakarta, 13 November 1957, p. 4.

22 Weekly Airmailer, 20 November 1957, p. 1.

23 Weekly Airmailer, 4 December 1957, pp. 17-18.

24 Weekly Airmailer, 4 December 1957, p. 1-2.

25 Weekly Airmailer, 12 December 1957, pp. 2-3.

26 Weekly Airmailer, 12 December 1957, p. 19.

27 The "Algemeen Landbouw Syndicaat" (ALS) was represented by W.H. Meijer and A.H. van Geuns, the "Algemeen Syndicaat van Suikerfabrikanten in Indonesië" (ASSI) by L. de Jong and C. van der Made, and AVROS by P. Rozendaal.

28 Resumé van de bespreking van de Minister van Landbouw met een delegatie van vertegenwoordigers van Nederlandse cultuurmaatschappijen op 10 December 1957 in het Ministerie van Landbouw te Djakarta, Jakarta, 10 December 1957.

29 Minister of Agriculture, Decree No. 247/UM/57.

30 Chief Justice Mahadi of the North Sumatran Provincial High Court later officially witnessed the signatures; Weekly Airmailer, 19 December 1957, p. 13.

31 Weekly Airmailer, 26 December 1957, pp. 18-19.

32 Staatsblad 1939, No. 582.

33 For example Djuanda's Decree No. 1063/PMT/1957 of 9 December 1957 was replaced by Ordinance No. 24/1958 of 17 April 1958, signed by both Sukarno and Sadjarwo. Sadjarwo's Decree No. 229/UM/57 was replaced by his Decree No. 49/UM/58 of 17 April 1958. These two legal documents permitted the continued supervision of Dutch plantations.

34 Herbert Feith, "Dynamics of Guided Democracy", in Indonesia, ed. Ruth T. McVey, p. 332.

35 Decree No. 225 superseded a similar decree issued in March 1957.

36 As it turned out later, the final target area approved for the tobacco industry was fixed at 60,911 hectares, of which 44,000 were assigned to the former United Deli Co., 15,000 to the former Senembah Co., and 1,911 to the Cinta Radja Co.

37 Gappersu letter No. 192/M, Jakarta, 3 March 1958.

38 Gappersu letter No. 160/Djk., Medan, 8 April 1958.

39 The figures for December 1957, 1958, and 1959 are taken from A.E. Johann, $A$ la Indonesia: Sorgen und Hoffnungen eines unfertigen Landes, Gütersloh, 1961, pp. 276-77. Johann's figures come from Gappersu. His figures for earlier years agree with my figures in Table 11, so that $I$ have no doubt about their validity.

40 See Waspada, 29 July 1958, and Mestika, 1 August 1958.

41 The order was No. PP/KPTS-0132/8/1958 issued on 14 August 1958.

42 Minister Sunarjo's decree was No. Sk. 224/Ka./1958. 
43 Suleika's letter No. 572/M of 4 September 1958 reports that the original plan provided for the representation of laborers, peasants, and Gappersu (i.e. planters) but that Sunarjo had crossed these out because he felt that their presence in the committee would only lead to delays.

44 Minister of Agriculture, Order No. 30/Um/58 of 3 March 1958.

45 In the other organizations, i.e. BUD and BAPPIT, the army officer served as director of the agency.

46 Berita Negara 1958, No. 162.

47 Ordinance No. 4. Ordinance No. 2 provided the guiding principles for implementation of the Nationalization Act. Ordinance No. 3 established a Nationalization Board of Dutch Enterprises (Badan Nasionalisasi Perusahaan Belanda, BANAS). These ordinances (Nos. 2, 3, and 4) were all signed and promulgated on 23 February 1959.

48 Ordinance No. 19 of 2 May 1957, promulgated on 20 May.

49 The full text of the Netherlands note of 28 February 1959 was released by The Netherlands Information Service in New York on 16 March 1959.

50 Minister of Agriculture Sadjarwo on Nationalization Act, Indonesian Spectator, 15 July 1959. 


\section{INDEX}

Aceh 89, 98-9, 147, 169

Agrarian Service of the Ministry of Interior 64, 80, 82

Agricultural Service of East Sumatra 71-3

Agung gde Agung, Anak 48

Ahem Erningpradja 76

Aidit, D.N. 28, 30-5, 39-40, 43, 45

aksi sepihak 43

ALS 163

Amien 117

Amin, S.M. 81, 106-7, 109, 128

army, military authority 38,147 . $51,153-6,160-9$

Asahan 48

Autochthonous, indigenous population 1-2, 5-7, 9-10, 14, 48, 50, $54-5,58,85,87-8,94,97-8$, $104,110,112-3,116,126,139$, 166

AVROS 85, 87, 91, 105, 107, 112$3,116-22,126-30,133,134,137$, 139-42, 146-9, 151-7, 163-4

Badan Pembantu Pemakaian Tanah Sumatera Timur (1955) 121, 126, 133,145

Bahri, Sjamsul 87

Bandarbaru 53

Bandung 58

Bank Indonesia 117, 160

Banyuwangi 43

BAPPIT 167

Batak 12, 14, 15, 22, 48, 92, 150

Belawan 101

bengkok 18

Binjai 2, 53, 69, 74, 79-81, 84, 123

BKOTSU 81

Blitar 19

Bogor 164

Bogor Declaration of 13 December 196443

BPM 158

BP4R 137

BPRP 54, 55, 57, 59, 69, 87, 94-6, $137,139,145$

Broeder, G. den 143

BTI $19-21,28,38,42-6,54-9,62$ $70,72-4,76,79-81,87-8,106-7$,
$109,129-34,137-46,150,166-7$

BUD 167

Bureau of Land (Use) Planning 7$16,51,60,87-8,97,153$

Bus de Gisignies, L.P.J. du 17

Capellen, G.A.G.F. van der 17

China, Chinese 5-6, 23, 35, 48, 54, $71-3,94,120$

Command for the Completion of Land Reform (Komando Penyelesaian Landreform) (1964) 41, 43

Committee for the Investigation of the Tanjungmorawa Affair and Land Distribution in East Sumatra (Panitya Peninjau Persoalan Peristiwa Tanjung Morawa dan Pembagian Tanah di Sumatera Timur) (1952) 73-4, 76

Committee for the Solution of Land Problems in North Sumatra (Panitya Penyelesaian Tanah Sumatera Utara) (1958) 166

Compulsory Cultivation Ordinance of 19305

Congo rebellion 38

Constitution of 1945 20, 39, 47

Constitution of 1950, Provisional $23,47-8,68,160$

Constitution of 1950, United States of Indonesia 47

Conversion question, rights $3,6,10$, $16,19-20,37,95$

Darman, L. 130, 132

Darul Islam 32

Decree of 28 June 1951 (No. 12/5/ 14) $52,59,78,81,84,90,117$ $8,121,125,129,142$

Decree of 28 September 1951 (No. 36/K/Agr.) 53, 59-60, 64, 78, 81 , $84,90,117-8,120-1,125,129$, 142

Deli 9, 48, 74, 84, 111, 124, 136, $146,148,150$

Deli Company 64, 69

Deli Plan (1950) 50-4

Deli Planters' Association 60, 62, 77

Demper, J.E. 113-4, 120, 126 
Depari, Kongsi Sembiring 86, 94

Djafar, Abdul 87, 101, 103

Djalaluddin, A.M. 133-4, 136, 145

Djanu Ismadi 83

Djomat Purba 1-2

Djuanda Kartawidjaja 158-61, 163, $167-8$

East Sumatran Agrarian Commission (Komisi Agraria Sumatera Timur) (1951) 52

Eck, D. van 143, 151

Effendy, Asjso 149

Emergency Law No. 8/1954, effective 12 June $1954106,108-9$, 114-5, 118-20, 122-3, 126-7, 129, $132,136,139,148$

Emergency Law No. 1/1956 136-8, 140,148

Executive Committee for the Solution of Plantation Land Disputes in East Sumatra (Badan Pelaksana Penyelesaian Sengketa Tanah Perkebunan Sumatera Timur) (1958) 166

Fernhout, J. 140, 151-3, 155-7, 164

forest reserve(s) 8-9, 41-3, 45, 51

Forest Service 40-2, 153

FPT 45,60

Gabungan Buruh Tani Tionghoa Sumatera Timur 54, 59, 68

Gaperta 54, 68, 137

Gappersu 164-5, 167

Geraktani 69, 74

Gerritsen, J. 1

Gintings, Lt. Col. Djamin 147-9, $150,161,166$

glebagan 18

GOBSII 57

Goodyear Company 38

Great Peasant Congress (Konperensi Besar Kaum Tani) (1953) 68

GTI 54, 56

Gunawan 122-3, 125-6, 145

Gunung Iskander 117

Haan, J.H. de 7, 8

Hafiz Haberham, Datuk 2

hak benda 53

hak guna-usaha 37, 41

hak memperusahai 50

hak milik 37, 50, 68 hak usaha 157

hak usaha atas tanah 23

Hakim, Abdul 28, 51, 53-4, 60, 62 $64-5,69-70,72-4,76,79-81,87-$ $4,90,100,110,112,121-2,132$

Hamzah, Suhunan 67-8, 71

Hanafiah, Mohammad (Minister) $87,107-8,110$

Hanafiah, Tengku 106-7

Harahap, Burhanuddin 122, 126, 128

Hardjasoemantri, R. Gaos 21

Hatta, Moh. 48, 159

Hazairin 80

Hermanses, R. 41, 46

HVA $11,145,151,169$

Indonesia, Republic of (1945-1949) $1,4,16,17-29,48,54$

Indonesia, United States of 13

Indonesian Peasant Congress, First (1945) 44

Indramayu Affair (1964) 42

Iskaq Tjokrohadisurjo 52, 90

Jakarta 2, 3, 7, 50-2, 64, 69, 87, $102,105-7,113-4,117,120$, $128,132-4,141,145,150-7$, $159-60,168$

jaluran rights, system 93-4, 96, $111-2,126,166$

Japanese Estates Control Board 44

Java, Javanese 5, 12, 15-20, 23, 30, $37,42-6,48,54-5,69,78,92$, $94,110,130,140,145,147$

Jawatan Perkebunan (Estates Service in the Department of Agriculture) $64,122,132,149,155$, 161

Jember 19

Joint Degree No. 1/1955 (30 June) $120,122-3,126,145$

Joint Proclamation of Tengku Mansur and Simbolon of 22 May $195013,51,105$

Joint Secretariat of Peasants Unions (Sekretariat Bersama Organisasi Tani Untuk Memperjuangkan Tanah Sumatera Timur) see Sekretariat Bersama

Kadir, Abdul 87, 94

Karo Batak 22, 64, 92, 147

Kasan 69-70 
Kasimo, I.J. 64, 90, 117, 122

KBKI 56

KBSI 56

Kertapati, Sidik 42, 73, 76, 78-80

Klaten 20

Kotjik, Tengku 145

KPM 160

KPPT (1951) 53, 60-6, 68-70, $72-$ $5,77,79-81,90,114,121-2,145$

KRPT (1955) 115, 121-2, 126, $144-5,148,150,166$

KTI 69, 74

Kumala Pontas, Sutan 128, 136, 143

Land Lease Regulation of the Principalities (Vorstenlandsche grondhuurreglement) 20

Langkat 9, 48, 62, 65, 69, 74, 79, $84,146,150$

Law, Agrarian (1870) 36

Law, Basic Agrarian (No. 5/1960) $32,36-7,39-41,48$

Law, Crop Sharing (No. 2/1960) $32,35-6,39-40$

Lembaga 106, 110, 131

Linggarjati Agreement 2

long leases $8,22-6,50,95,115$, $118,151,153,157,159$

Lubukpakam 2, 71

Lynden, Baron van 8

Made, C. van der 151

Madiun coup 30

Maengkom, G.A. 160

Mahadi 111

Makmur, Lt. Col. Wahab 147

Malaysia issue 38

Manik, M. 164

Manipol 39

Manipol-USDEK 36, 39

Mansur, Tengku 2-4, 13, 48, 51

Manuaba, I.B. 70

Marihat Estate 11-5

Masyumi 28, 54, 56-8, 64, 78, 81, $83,87-8,100,110,128,131$, 145,160

Medan 1-2, 9, 48, 53, 55, 59, 64-5, $69-71,73-4,76,83-4,87-8,107$, $110-1,114,117,122,127,130$, $133-4,138,141,145-8,158,165$ Mestika 58, 65, 106, 131, 133

Military see army
Mimbar Umum 58, 106, 111, 130, 133

Minister of Agrarian Affairs 37, 41-3, 46, 84-6, 107, 110-8, 120-2, $134,136,141,150-7,166,169$

Minister of Agriculture 42, 107, $115,120,154-5,161-3,167,170$

Minister of Defense 162-3

Minister of Economic Affairs 107, 115,120

Minister of Forestry 42

Minister of Interior, Internal Affairs $25,28,43,52-3,73,76-7,80,90$, $107,115,120$

Minister of Justice 107, 115, 120

Ministerial Committee on Agrarian Matters 42-3

Ministry, Department of Agrarian Affairs $41,80,82-3,87,105$, $108,113-5,117-9,122,132,145$, $152,155-6,165,167$

Ministry, Department of Agriculture $34,52,60,64,75,82-3,87$, $117,120,122,132,152,155$, 167

Ministry of Defense 152

Ministry of Finance 152, 159

Ministry of Interior 21, 51-2, 62, 65,83

Ministry of Justice 41, 132

Ministry of Labor 167

Molen, K. van der 101, 114

Mook, H.J. van 2

Muda Dalam, Jusuf 90

Mudjoko, Brig. Gen. 42

Munaba 73

Munar Hamidjojo 49, 52

Nasakom 39, 42-3

Nasution, Maj. Gen. 161-2, 167-9

Nasution, M. Yunan 83

National Front 41-2

National Land Reform Committee 46

National Program July 1949 21-2, 24

Natsir, Mohammad 68, 125

Negara Sumatera Timur 1, 3-7, 9, $11,13-5,17,47-50,54-5,58$

Netherlands-Indonesian Union 68, 127-8

NHM 141-2, 169 
Nolen, R. 87, 103, 105-8, 111-4, $116,118-20,122-3,126-7,132-5$, 137,140

NU 43, 46, 56, 145, 166

O B Pancasila 57

OBSI 130

oil palm estates 169

Order 1 May 1947 of Republican Resident 5

Ordinance 8 June 1948 No. 110 against squatting $5,14,51,105$, 108-9, 129

pajeg 17-8

Pancasila 36, 39

Panitya Agraria Jakarta (1951) 21

Panitya Agraria Yogyakarta (1948) $21,23,26$

Panitya Tanah Konversie (1948) 17,20

PARDIST 2

Parkindo 57, 111

Partai Katolik Indonesia 57, 64, 134

Peasant Front of East Sumatra (Front Tani Sumatera Timur) 59

\section{Pedoman 159}

Pematangsiantar 2, 11

Pemuda Rakyat 42, 69

Pendorong 55, 67, 111

perennial-crop estates $3,8-9,49$, $75,81,84-5,87,90-1,93-4,96-7$, $117,120-1,151,153,155,165$, 169

Petani 43, 46, 55-6, 59, 64-5, 69-70, 73, 76, 80-1, 87-8, 106-7, $109,133,137,139,145,149$, 166

Petanu 43, 46, 56

PIR 80

PKI 28, 30-46, 56, 60, 69, 73-4, $78-80,111,131$

PKI, Fifth National Party Congress (1954) 30

PKI, Sixth National Party Congress (1959) 32-3

PKI, First National Peasants' Conference (1959) 31

PNI 28, 43, 55-6, 60, 65, 69-70, $73,78,80-1,88,128,131,167$

PPN 37-9, 43, 87, 130, 153, 161

PPN-Baru 161-2, 164, 167-9
PPNKST 48, 51, 62

P4SU 49

PPUTP 49-50

Principalities (Yogyakarta-Surakarta) $17-20$

PRN 55, 57, 87, 110, 122, 145

Proclamation of 19 March 1954 106

Proclamation of 6 April 1954106

Proclamation of 12 July 1954107

PRRI-Permesta movement 32

PSI 54, 56-7, 81, 130

PSII 46, 57

PST 2

Radjamin 87-8, 97, 100

Rake, I. Gusti Gde 110-21, 126

Rangkuty, M.J. 130

Rasjid, Mohammad 74

RCMA 164, 169

Roem, Mohamad 28, 74, 76, 78

Round Table Conference, Agreement $16,24,45,50,58,64,68$, $81,127,132,169,170$

Rozendaal, P. 114, 151, 164

RTI 44-5，54-9，62-3，68-70，74, 137

rubber estates $124,165,169$

Sadjarwo 42-3, 155, 162-3, 167, 170

Said, Mohammad 65

Sakti 44-5, 56-7, 68-9, 73, 137

Sarbumusi 56

Sarbupri 38

Sardjono, S. 73, 76

Sarimin Reksodihardjo 21, 48-9, 51,62

Sastroamidjojo, Ali 78-80, 83-4, $101,110,122,126,128,132$, 147

SBII 56

SBKI 57

Scholten, Col. P. 1

Secanggang 66-7, 73, 81

Sekata 54, 59, 68

Sekretariat Bersama 68-9, 71-4, 79, $87,92-3,101,106,149$

Selamat Sejahtera 2

Senan 66-8

Senembah Company 71, 130, 135, $138,164,169$

Serdang 9, 48, 72, 74, 84, 111, 
$124,136,146,148,150$

Shell Oil Company 78

Simbolon, Col. M. 13, 51, 147

Simelungun 1, 11-2, 14-5, 48, 64, $69,124,145,147-8,156-7$

Singgih Praptodihardjo 87-8, 102-4, $107,109,113-21,145,156-7$

Siregar, Purnama 69, 74

sisal estates, industry, plantations 92, 124, 153, 155-6, 165, 169

Sjafruddin Prawiranegara 160

SOBSI 38, 56, 69, 79, 134, 158

Social Revolution 1, 6

Soepomo, R. 17-8, 23, 67

squatters, squatting 5-6, 9, 11-5, 24-5, 28, 43, 45, 48, 51-2, 60-3, $65-74, \quad 79-81, \quad 84-7, \quad 89-92$, $99-100,112-3,116,118-41,143$, $145-50,152-7,165-6$

Standfast 27 August 1953 83, 103, $105-9,120$

Standfast 12 June 1954 107, 109, $123,126,128,133,135,137-9$, $148-50,154,156$

State Commission for the Division of Estate Lands in East Sumatra (Panitya Negara Urusan Pembagian Tanah Perkebunan Sumatera Timur) (1953) 79, 83-106, $108,110-1,113-4,116-7,122$, 139,149

STII 20-1, 46, 54-6, 59, 69, 74, $87-8,100,133,137,139,145$

Suara Rakjat 55, 65

Subakti Pusponoto 87

Subandrio, Dr, 42

Sudibjo 158-9

Sudjarwo 42

sugar plantations, factories, industry 20-1, 44

Sugi Arto, Lt. Col. 147

Suhardi 134

Sukarno 17, 20-1, 36, 38-41, 78, $159,164,169$

Sukiman Wirjosandjojo 58, 68, 90, 125

Suleika, J. 164-5

Sumatra Planters Association (Gabungan Pengusaha Perkebunan Sumatera) 164

Sunarjo 151-2, 154-6, 166
Supangat, Imam 122, 145

Surabaya 158

Surakarta 17, 20

Tampubolon, R. 111

Tangkas 106, 130-1

Tanjungmorawa 28, 68, 70-4, 81

Tanjungpura 53, 67

Tapanuli 5, 12, 23, 48, 64, 81, 89, $92,95,98-9,130,147,150$, 156-7

tara lands $94,135,155$

Tarigan, D.S. 158

Tarigan, S.M. 68, 71, 86-7, 93-4, $131-2,140,144-5,149-50$

tea estates $156,165,169$

Tebingtinggi 53,71

TII 42

Tjerdas 131

Toba Batak 22-3, 48, 110-1, 147

tobacco plantations, estates, industry, 3, 7-10, 20, 44, 49-53, 60-1, $63,70,74-6,79,81,84-7,90-1$, $93,95-6,101,112,115,117$, $120-1,124,126,129-30,132$, $134-40,144,148-50,152-3,155$, 166,169

Ular river 86, 130

Uniroyal Company 38

United Deli Company 101-2, 113, $130,134-5,137,139-46,151$, $164,166,169$

United Front of Peasant Organizations of North Sumatra (Kesatuan Aksi Organisasi Tani-Tani Sumatra Utara) 146

United Nations 158-9, 170

Urgency Program (1950) 49, 51, 62

Velde, J.J. van de 1, 2

Vietnam war 38

Vollenhoven, C. van 17-8

Vorstman, E.M. 87, 103, 114, 139

Wahid Er, Abdul 108

Wampu river 86,130

Wasitohardjo, Ali 150

Waspada 55, 65, 70

West Irian crisis, issue $68,127,157$ $61,163,169,170$

Wilopo $28,58,64,68,76,78,83$, $87,100,125,131$

Yogyakarta 17, 20, 54

Zain Hamid, Major 148 